LA-14169

Approved for public release;

distribution is unlimited.

Nonradioactive Ambient Air Monitoring

at Los Alamos National Laboratory

2001-2002

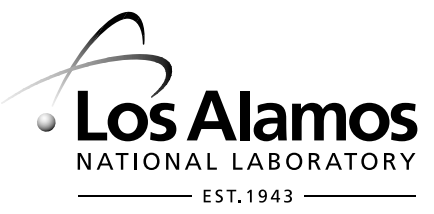

The World's Greatest Science Protecting America 


\section{Edited by Hector Hinojosa, Group IM-1}

Los Alamos National Laboratory, an affirmative action/equal opportunity employer, is operated by the University of California for the United States Department of Energy under contract W-7405-ENG-36.

This report was prepared as an account of work sponsored by an agency of the United States Government. Neither the Regents of the University of California, the United States Government nor any agency thereof, nor any of their employees make any warranty, express or implied, or assume any legal liability or responsibility for the accuracy, completeness, or usefulness of any information, apparatus, product, or process disclosed, or represent that its use would not infringe privately owned rights. Reference herein to any specific commercial product, process, or service by trade name, trademark, manufacturer, or otherwise does not necessarily constitute or imply its endorsement, recommendation, or favoring by the Regents of the University of California, the United States Government, or any agency thereof. The views and opinions of authors expressed herein do not necessarily state or reflect those of the Regents of the University of California, the United States Government, or any agency thereof. Los Alamos National Laboratory strongly supports academic freedom and a researcher's right to publish; as an institution, however, the Laboratory does not endorse the viewpoint of a publication or guarantee its technical correctness. 
LA-14169

Issued: September 2004

\section{Nonradioactive Ambient Air Monitoring at Los Alamos National Laboratory 2001-2002}

Ernest Gladney

Craig Eberhart

Jean Dewart

Joseph Lochamy* 



\section{Contents}

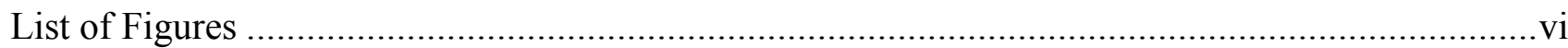

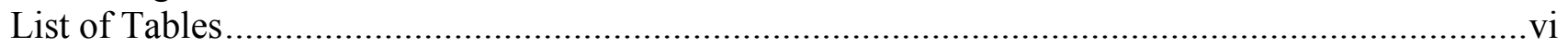

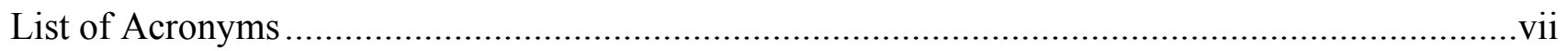

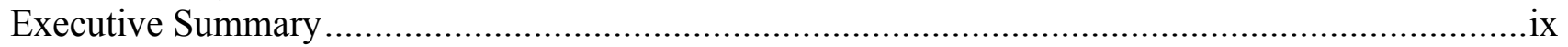

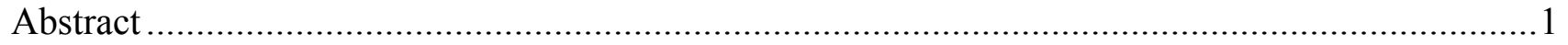

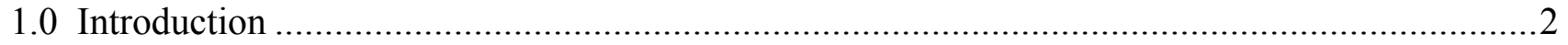

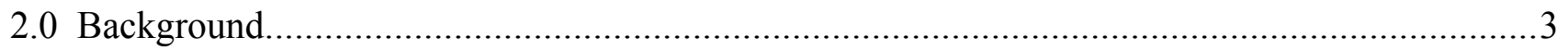

3.0 NonRadNET Air Monitoring Network ........................................................................ 4

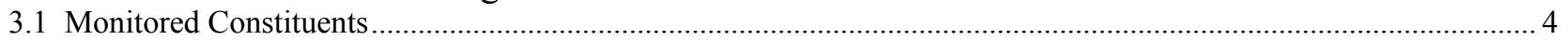

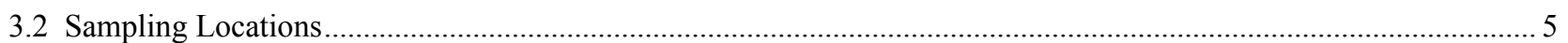

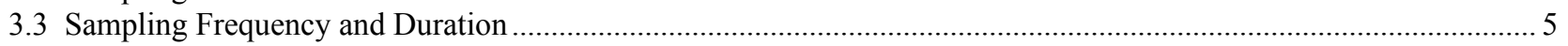

4.0 Sampling Procedures, Analytical Methods, Data Management, and Quality Assurance .............6

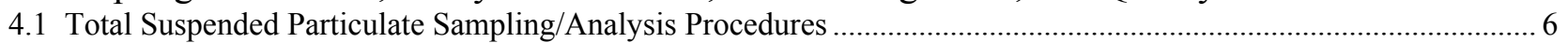

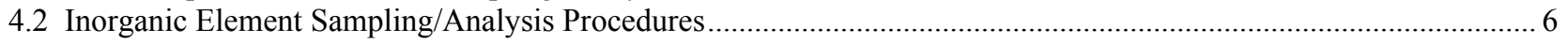

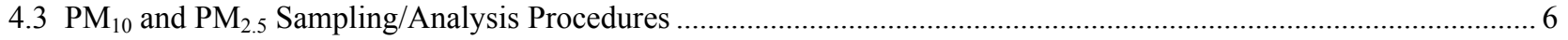

4.4 Volatile Organic Compound Sampling/Analysis Procedures........................................................................................ 7

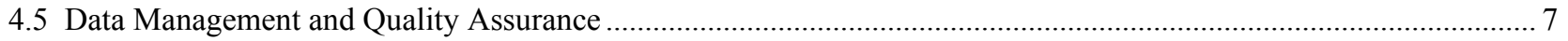

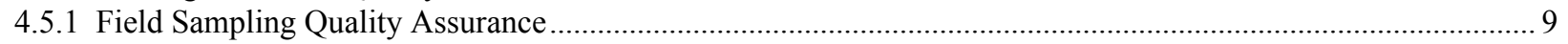

4.5.2 Analytical Laboratory Quality Assessment ....................................................................................................... 9

4.5.3 Evaluation of Field and Analytical Data Quality Control Results ..................................................................... 9

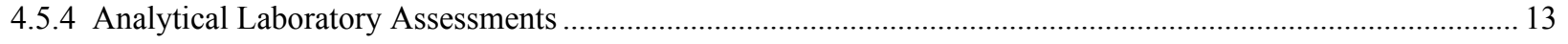

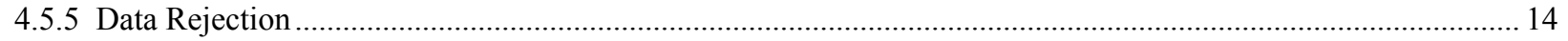

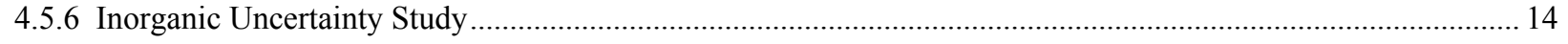

5.0 Origins and Uses of Nonradioactive Species in Ambient Air .........................................15

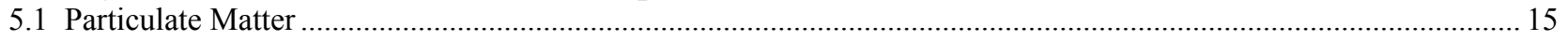

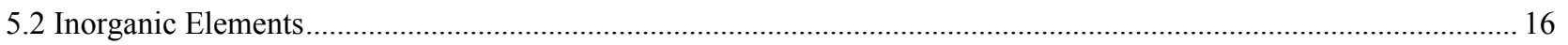

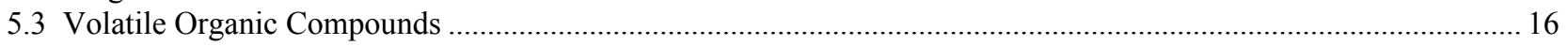

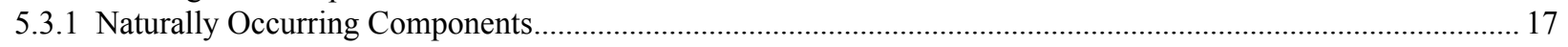

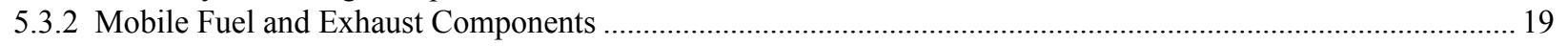

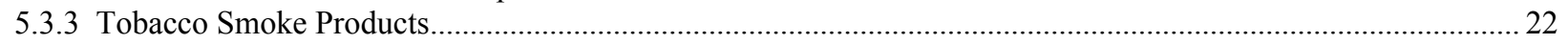

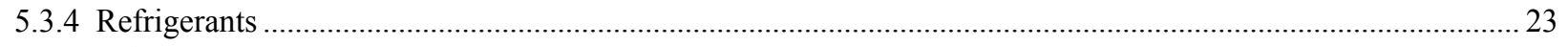

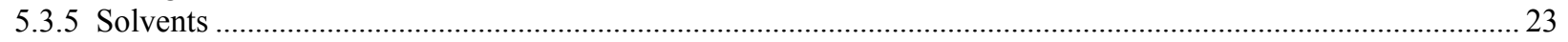

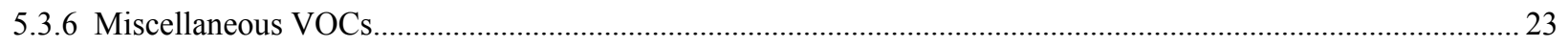

6.0 Comparison with LANL and Other Emission Sources ...................................................26

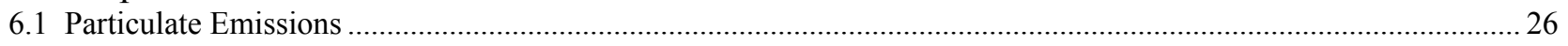

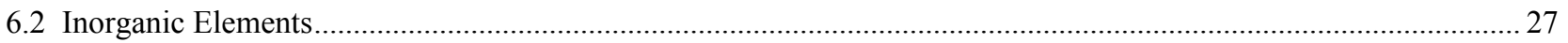

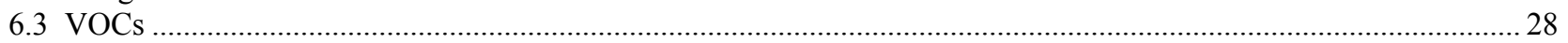

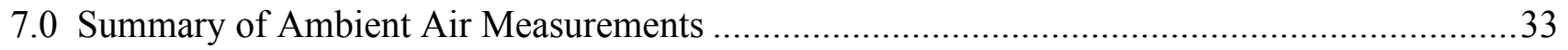

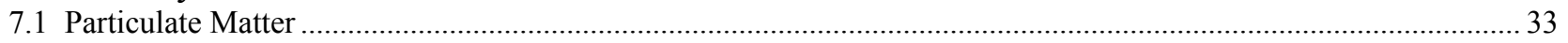

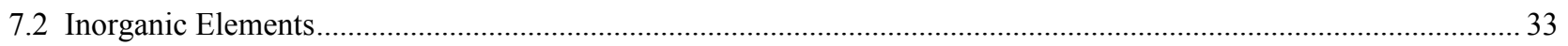

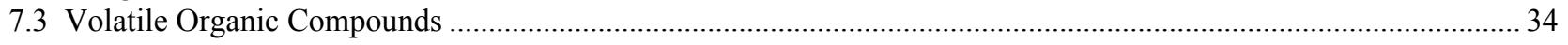

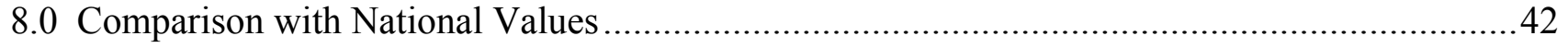

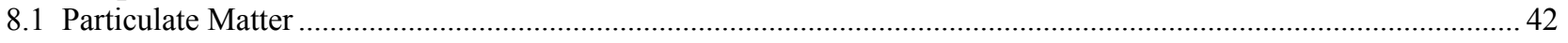

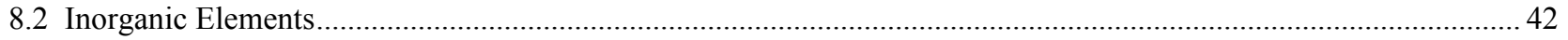

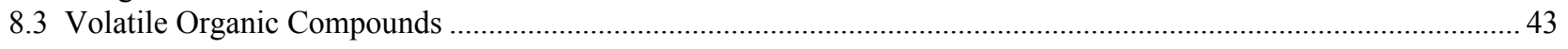

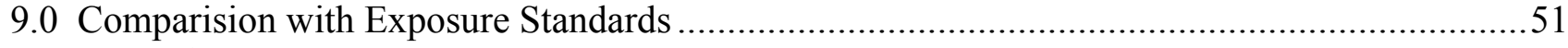

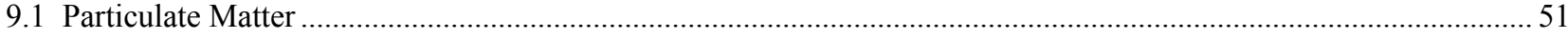

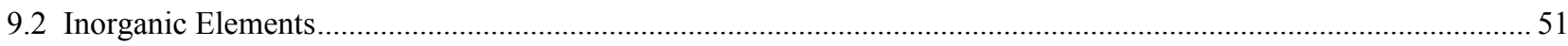

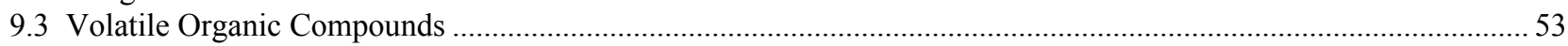

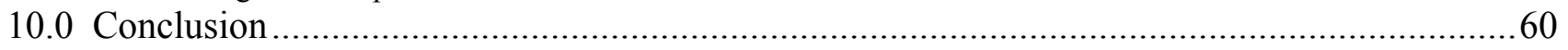




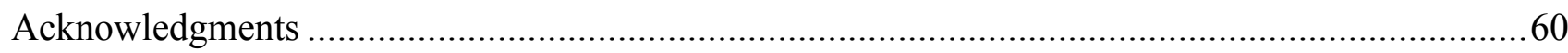

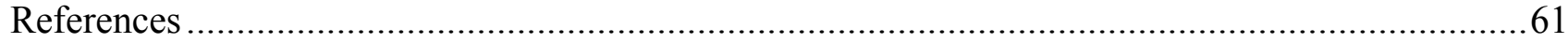

APPENDIX A Comprehensive NonRadNET VOC Data..........................................................63

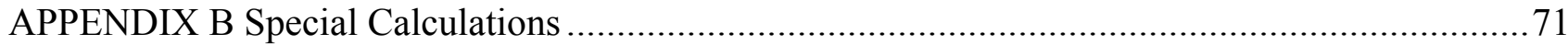

\section{List of Figures}

Figure 4-1. TEOM sampling equipment inside an enclosure at Site \#61_.............................................. 8

Figure 4-2. Ambient Volatile Organic Collection System at Site \#61 ..................................................... 8

\section{List of Tables}

Table 3-1. NonRadNET Inorganic Elements

Table 4-1. VOC Surrogate Recovery Summary for 2001-2002 ……................................................

Table 4-2. LCS Recovery Summary for Inorganics for 2001-2002 ………………………..................11

Table 4-3. LMS Recovery Summary for Inorganics for 2001-2002 ………………………………....12

Table 4-4. Detection Limit Summary for Inorganics for 2001-2002 ……………………….................13

Table 4-5. Comparison of ICPES and ICPMS Concentration Results .....................................................14

Table 5-1. Human-Made Sources/Uses of NonRadNET Inorganic Elements ............................................17

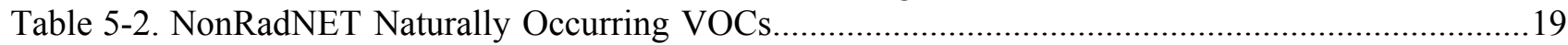

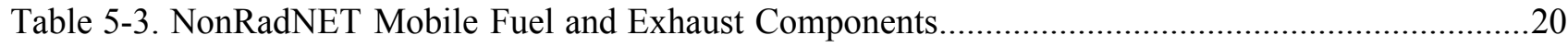

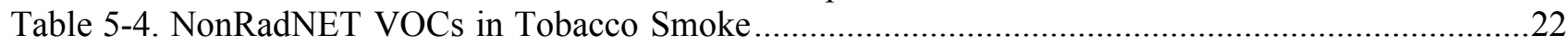

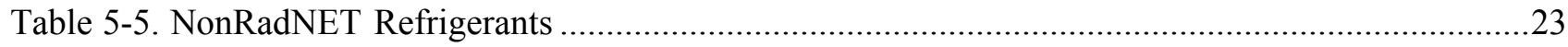

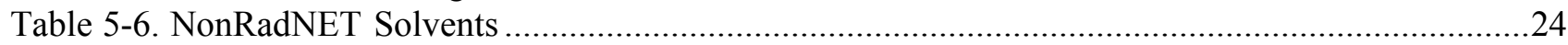

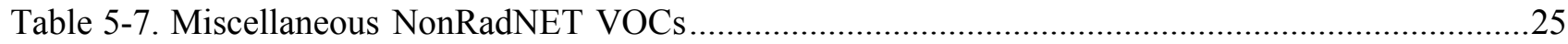

Table 6-1. NonRadNET HAPs Inorganic Elements Used at LANL ………………………….................27

Table 6-2. Other NonRadNET Inorganic Elemental Chemicals Used at LANL..........................................27

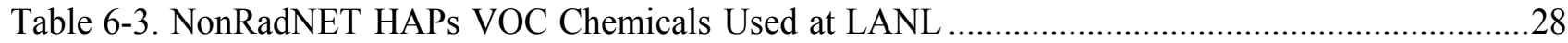

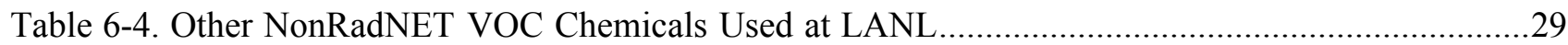

Table 6-5. Frequently Detected LANL VOC Chemical Usage Not Found in Vehicle Emissions ...............30

Table 7-1. Average Concentrations of NonRadNET Particulate Matter ......................................................33

Table 7-2. Average Concentrations of NonRadNET Inorganic Elements..................................................34

Table 7-3. Average Concentrations of VOCs Detected in $>50 \%$ of NonRadNET Samples .......................36

Table 7-4. Average Concentrations of VOCs Detected in 10\% to 50\% of NonRadNET Samples .............39

Table 7-5. Average Concentrations of VOCs Detected in $<10 \%$ of NonRadNET Samples ........................40

Table 8-1. LANL Inorganic Measurements Compared to Typical National Values ....................................43

Table 8-2. Comparison of National Values with VOCs Detected in $>50 \%$ of NonRadNET

Samples

Table 8-3. Comparison of National Values with VOCs Detected in $10 \%$ to $50 \%$ of

NonRadNET Samples

Table 8-4. Comparison of National Values with VOCs Detected in $<10 \%$ of NonRadNET

Samples

Table 9-1. Comparison of NonRadNET Particulate Measurements to EPA and New Mexico

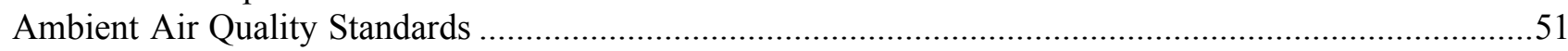

Table 9-2. Comparison of NonRadNET Elemental Measurements to Limits ...........................................52

Table 9-3. Occupational TWAs for NonRadNET VOCs Detected With $>50 \%$ Frequency.........................54

Table 9-4. Occupational TWAs for NonRadNET VOCs Detected With 10\% to 50\% Frequency...............57

Table 9-5. Occupational TWAs for NonRadNET VOCs Detected With $<10 \%$ Frequency....................... 58 


\section{List of Acronyms}

ACGIH American Conference of Governmental Industrial Hygienists

ACIS Automated Chemical Inventory System

AIHA American Industrial Hygiene Association

ATSDR Agency for Toxic Substances and Disease Registry

CAS Chemical Abstract Service

DQO Data Quality Objective

EPA Environmental Protection Agency

EPCRA Emergency Planning and Community Right-to-Know Act

ESH-17 former designation for the Meteorology and Air Quality Group

HAP Hazardous Air Pollutant

ICPES inductively coupled plasma emission spectrometry

ICPMS inductively coupled plasma mass spectrometry

LANL Los Alamos National Laboratory

LCS laboratory control standards

LMS laboratory matrix spikes

$\mu \mathrm{g} / \mathrm{m}^{3}$ micrograms per cubic meter

MAQ Meteorology and Air Quality Group

MSDS Material Safety Data Sheet

NATA National Air Toxics Assessment

$\mathrm{ng} / \mathrm{m}^{3}$ nanograms per cubic meter

OSHA Occupational Safety and Health Administration

PAMS Photochemical Assessment Monitoring Station

$\mathrm{PM}_{2.5}$ particulate matter with an aerodynamic diameter of 2.5 micrometers or less

$\mathrm{PM}_{10}$ particulate matter with an aerodynamic diameter of 10 micrometers or less

ppbv parts ber billion by volume

SOW Statement of Work

STL Severn-Trent Laboratories

TA Technical Area

TEOM tapered element oscillating microbalance

TSP total suspended particulate

TWA time weighted average

UATMP Urban Air Toxics Monitoring Program

VOCs volatile organic compounds 


\section{Executive Summary}

During the spring of 2000, the Cerro Grande forest fire reached Los Alamos National Laboratory (LANL) and ignited both above-ground vegetation and disposed materials in several landfills. During and after the fire, there was concern about the potential human health impacts from chemicals emitted by the combustion of these Laboratory materials. Consequently, short-term, intensive air-monitoring studies were performed during and shortly after the fire. Unlike the radiological data from many years of AIRNET sampling, LANL did not have an adequate database of nonradiological species under baseline conditions with which to compare data collected during the fire. Therefore, during 2001 the Meteorology and Air Quality Group designed and implemented a new air-monitoring program, entitled NonRadNET, to provide nonradiological background data under normal conditions. The objectives of NonRadNET were to

- develop the capability for collecting nonradiological air-monitoring data,

- conduct monitoring to develop a database of typical background levels of selected nonradiological species in the communities nearest the Laboratory, and

- determine LANL's potential contribution to nonradiological air pollution in the surrounding communities.

NonRadNET ended in late December 2002 with five quarters of data. The purpose of this paper is to organize and describe the NonRadNET data that was collected over 2001-2002 to facilitate future use as baseline data, either for monitoring during a fire, some other abnormal event, or routine use. To achieve that purpose, in this paper we will

- document the NonRadNET program procedures, methods, and quality management,

- describe the usual origins and uses of the species measured,

- compare the species measured to LANL and other area emissions,

- present the five quarters of data,

- compare the data to known typical environmental values, and

- evaluate the data against exposure standards.

Three samplers were operated according to a documented quality assurance plan during the fivequarter sampling period. The three samplers were located at

White Rock Fire Station (site \#15)

Los Alamos Medical Center (site \#61)

Intersection of Diamond Drive and East Jemez Road (site \#81)

As part of the program, the samplers collected total suspended particulate matter, particulate matter less than 10 microns, and particulate matter less than 2.5 microns. Concentrations were typical for the nation and region.

Air samples were also collected and analyzed for 20 inorganic elements. The concentrations of these elemental species were also observed generally to be typical for the region and nation with barium, beryllium, iron, and vanadium concentrations being somewhat higher, but still less than values from urban areas. 
Finally, we measured approximately 160 volatile organic compounds (VOCs) in our air samples. We determined that about half of the 160 VOCs measured are common components of vehicle fuels and exhausts. We also determined that virtually all of the rest of the VOCs are also components of everyday consumer or industrial processes. Furthermore, we determined that the concentrations for nearly all of the measured species, for which there were comparison data, were less than or within typical national concentration ranges.

We did observe that the concentrations for benzaldehyde, butyraldehyde, acetone, and acetaldehyde appear to be higher than the few national values we found for comparison with them. Our review of the very low LANL emissions of these four VOCs indicated that their airborne concentrations cannot reasonably be attributed to LANL. However, we conservatively concluded that 2, 4, 4-trimethyl-1pentene and Freon 22 (chlorodifluoromethane) may have measurable LANL influence or may have LANL as their primary origin. Additionally, we observed that normal commuter vehicle use, by far, emits more VOCs than LANL.

Based on our measurements, our evaluation of LANL and other emission sources, and a comparison of our results with typical national values, we conclude that the Laboratory is not a significant contributor to the large number of species we measured. Furthermore, the ambient air concentrations around LANL tend to be significantly lower than in major urban areas, roughly typical of rural areas, and are many orders of magnitude below regulatory standards considered safe for occupational exposure (since environmental exposure standards do not exist for most of these species). 


\title{
NONRADIOACTIVE AMBIENT AIR MONITORING AT LOS ALAMOS NATIONAL LABORATORY 2001-2002
}

\author{
by \\ Ernest Gladney, Craig Eberhart, Jean Dewart, and Joseph Lochamy
}

\begin{abstract}
During the spring of 2000, the Cerro Grande forest fire reached Los Alamos National Laboratory (LANL) and ignited both above-ground vegetation and disposed materials in several landfills. During and after the fire, there was concern about the potential human health impacts from chemicals emitted by the combustion of these Laboratory materials. Consequently, short-term, intensive air-monitoring studies were performed during and shortly after the fire. Unlike the radiological data from many years of AIRNET sampling, LANL did not have an adequate database of nonradiological species under baseline conditions with which to compare data collected during the fire. Therefore, during 2001 the Meteorology and Air Quality Group designed and implemented a new air-monitoring program, entitled NonRadNET, to provide nonradiological background data under normal conditions. The objectives of NonRadNET were to

- develop the capability for collecting nonradiological air-monitoring data,

- conduct monitoring to develop a database of typical background levels of selected nonradiological species in the communities nearest the Laboratory, and

- determine LANL's potential contribution to nonradiological air pollution in the surrounding communities.
\end{abstract}

NonRadNET ended in late December 2002 with five quarters of data. The purpose of this paper is to organize and describe the NonRadNET data collected over 2001-2002 to use as baseline data, either for monitoring during a fire, some other abnormal event, or routine use. To achieve that purpose, in this paper we will

- document the NonRadNET program procedures, methods, and quality management,

- describe the usual origins and uses of the species measured,

- compare the species measured to LANL and other area emissions,

- present the five quarters of data,

- compare the data to known typical environmental values, and

- evaluate the data against exposure standards. 


\subsection{Introduction}

This paper provides a description of a short-term nonradiological air-monitoring program, "NonRadNET," at Los Alamos National Laboratory (LANL) that operated for 15 months from the fourth quarter of 2001 through the end of 2002. It also provides the entire data set for the sampled period and consists of results for 183 nonradioactive species, including particulate matter in three size ranges, 20 inorganic elements, and 160 volatile organic compounds (VOCs). The results of this program were first published in the LANL Environmental Surveillance Reports for 2001 and 2002 [LANL2002, LANL2003]. The VOC data reported in the Environmental Surveillance Reports are in units of parts per billion by volume (ppbv), a convenient analytical unit. In this report, we will use the more conventional air concentration units of micrograms per cubic meter $\left(\mu \mathrm{g} / \mathrm{m}^{3}\right)$.

The purpose of this paper is to organize and describe the NonRadNET data that was collected over 2001-2002 for future use as baseline data, either for monitoring during a fire, some other abnormal event, or routine use. To achieve that purpose, in this paper we will

- document the NonRadNET program procedures, methods, and quality management,

- describe the usual origins and uses of the species measured,

- compare the species measured to LANL and other area emissions,

- present the five quarters of data,

- compare the data to known typical environmental values, and

- evaluate the data against exposure standards.

Besides the Executive Summary, this paper is divided into 10 major technical sections, plus a references section, and two appendices.

Section 1, Introduction, is intended to provide information on the purpose and structure of the paper and a very general overview. Section 2, Background, provides a historical perspective on why the program was begun and gives the objectives of the program. Section 3, NonRadNET Air Monitoring Network, provides a general description and overview of the NonRadNET program. Section 4, Sampling Procedures, Analytical Methods, Data Management, and Quality Assurance, provides a more detailed description of the specific program components. Section 5, Origins and Uses of Nonradioactive Species in Ambient Air, describes where many of the measured species originate and some of their common uses. Section 6, Comparison with LANL and Other Emission Sources, cross tabulates the measured species with those used at LANL. Section 7, Summary of Ambient Air Measurements, discusses the measured results in terms of averages and ranges. Section 8, Comparison with National Values, puts the LANL measurements into perspective by comparing them to typical national concentrations. Section 9, Comparison with Exposure Standards, further adds perspective by comparing the measurements with exposure standards, most of which are occupational rather than environmental, since environment exposure standards generally do not exist for the measured species. Section 10, Conclusion, makes a final statement regarding achievement of the program objectives. Section 11, References, provides the references, many of which are web sites, used in the paper or recommended for further information. References are indicated in square brackets "[Reference]" in the document body.

Appendix A provides a listing of the 160 VOCs included in this project. Appendix B contains the details of several special calculations, the results of which are used in the main text of this document. 


\subsection{Background}

During the spring of 2000, the Cerro Grande forest fire reached LANL and ignited both aboveground vegetation and disposed materials in several landfills. During and after the fire, there was concern about the potential human health impacts from chemicals emitted by the combustion of these Laboratory materials. Consequently, short-term, intensive air-monitoring studies were performed during and shortly after the fire. Unlike the radiological data from many years of AIRNET sampling, LANL did not have an adequate database of nonradiological species under baseline conditions with which to compare data collected during the fire. Therefore, during 2001, the Meteorology and Air Quality Group (MAQ, formerly ESH-17) designed and implemented a new air-monitoring program, entitled NonRadNET, to provide nonradiological background data under normal conditions. The objectives of NonRadNET were to

- develop the capability for collecting nonradiological air-monitoring data,

- conduct monitoring to develop a database of typical background levels of selected nonradiological species in the communities nearest the Laboratory, and

- determine LANL's potential contribution to nonradiological air pollution in the surrounding communities.

These objectives will be addressed in this paper. The next section describes how the capability for collecting nonradiological air-monitoring data was developed. 


\subsection{NonRadNET Air Monitoring Network}

This section provides a brief overview of the NonRadNET Air Monitoring Network.

\subsection{Monitored Constituents}

NonRadNET was designed to sample and analyze environmental levels of airborne nonradiological constituents in Los Alamos County. The species monitored included

- total suspended particulates (TSP),

- particulate matter with an aerodynamic diameter of 10 micrometers or less $\left(\mathrm{PM}_{10}\right)$,

- particulate matter with an aerodynamic diameter of 2.5 micrometers or less $\left(\mathrm{PM}_{2.5}\right)$,

- 20 inorganic elements of particulate matter, and

- 160 VOCs.

The 20 monitored inorganic elements are given in Table 3-1 below.

Table 3-1. NonRadNET Inorganic Elements

\begin{tabular}{|l|c|}
\hline \multicolumn{1}{|c|}{ Name } & Symbol \\
\hline Antimony & $\mathrm{Sb}$ \\
\hline Arsenic & $\mathrm{As}$ \\
\hline Barium & $\mathrm{Ba}$ \\
\hline Beryllium & $\mathrm{Be}$ \\
\hline Cadmium & $\mathrm{Cd}$ \\
\hline Cerium & $\mathrm{Ce}$ \\
\hline Chromium & $\mathrm{Cr}$ \\
\hline Cobalt & $\mathrm{Co}$ \\
\hline Copper & $\mathrm{Cu}$ \\
\hline Iron & $\mathrm{Fe}$ \\
\hline Lead & $\mathrm{Pb}$ \\
\hline Manganese & $\mathrm{Mn}$ \\
\hline Neodymium & $\mathrm{Nd}$ \\
\hline Nickel & $\mathrm{Ni}$ \\
\hline Selenium & $\mathrm{Se}$ \\
\hline Silver & $\mathrm{Ag}$ \\
\hline Strontium & $\mathrm{Sr}$ \\
\hline Thallium & $\mathrm{Tl}$ \\
\hline Vanadium & $\mathrm{V}$ \\
\hline Zinc & $\mathrm{Zn}$ \\
\hline
\end{tabular}

Because the list of VOCs is rather long, two complete lists of the approximately 160 monitored VOCs, ordered alphabetically and by Chemical Abstract Service (CAS) number, are provided in Appendix A and are not reproduced here. 


\subsection{Sampling Locations}

NonRadNET sampling locations were chosen using siting criteria based on Environmental Protection Agency (EPA) specifications in 40 CFR Part 58 [EPA1999] and the MAQ air sampler siting procedure [LANL2000]. Monitoring stations were designed to collect samples in the breathing zone: two meters above the ground surface. Uniform application of these criteria assured consistency, comparability, and representativeness among all air sampling locations. In addition to the site-specific criteria cited above, good scientific judgment was always employed as the final criterion in selecting the optimal sampling locations.

Simultaneous monitoring took place at three different locations - two in Los Alamos and one in White Rock, NM. The White Rock NonRadNET sampling (site \#15) was co-located with the existing AIRNET station at the White Rock Fire Station. One of the Los Alamos stations (site \#61) was co-located with the existing AIRNET station at the Los Alamos Medical Center. The third NonRadNET station (site \#81) was located near the intersection of Diamond Drive and East Jemez Road between the main technical area of the Laboratory and the population center of the Los Alamos town.

\subsection{Sampling Frequency and Duration}

$\mathrm{PM}_{10}$ and $\mathrm{PM}_{2.5}$ concentrations were measured continuously and averaged over 1-hour, 3-hour, and 24-hour time periods. VOC, TSP, and inorganic sampling was done every twelfth day to coincide with the EPA national ambient air monitoring schedule, with each sampling period lasting 24 hours. All sites commenced operation on September 22, 2001. Sampling ended five quarters later on December 23, 2002. Meteorological data were collected through the LANL meteorological monitoring network and used to aid in data interpretation and impact evaluation. 


\subsection{Sampling Procedures, Analytical Methods, Data Management, and Quality Assurance}

This section describes the procedures used for NonRadNET sampling, the methods used to determine the constituents, how the data were handled, and the quality assurance features of NonRadNET.

\subsection{Total Suspended Particulate Sampling/Analysis Procedures}

The total suspended particulate sampling was done using high-volume particulate samplers. These samplers operate on the same principle as a vacuum cleaner. A calibrated volume of air is drawn through a pre-weighed filter for exactly 24 hours. Particles are trapped on the filter. After the 24hour period the filter is collected and weighed. The change in weight of the filter pad is recorded as micrograms of particulate per cubic meter of air sampled. For the NonRadNET study, samples for 24-hour time-integrated TSP were collected on either Dynaweb polypropylene or Whatman cellulose 8- by 10-inch filters using Anderson GV-2360 volumetric-flow-controlled high-volume samplers. All filters were placed in the sampler less than 48 hours prior to the start of a sampling run and were recovered from the samplers within 24 hours of the end of each sampling period. All filters were weighed prior to deployment and again after collection to determine net particulate weight gain. All weighing activities took place in a humidity-conditioned chamber. Filters were equilibrated for at least 24 hours prior to each weighing to achieve consistent absorbed-water levels.

\subsection{Inorganic Element Sampling/Analysis Procedures}

After determining the TSP on the filters, they were then sent to a commercial environmental analytical chemistry laboratory in glassine envelopes under chain of custody for chemical analysis of 20 inorganic elements via both inductively coupled plasma emission spectrometry (ICPES) using EPA Method SW6010 and inductively coupled plasma mass spectrometry (ICPMS) using EPA Method SW6020.

\section{3 $\mathrm{PM}_{10}$ and $\mathrm{PM}_{2.5}$ Sampling/Analysis Procedures}

$\mathrm{PM}_{10}$ and $\mathrm{PM}_{2.5}$ can be sampled using traditional filter-based sampling techniques as described in Section 4.1 for TSP or by continuous in-situ monitors. The benefits of continuous in-situ monitors are as follows: (1) reduced site visits and monitoring network operating costs, (2) collection of realtime data to assist in decision making, such as air quality alerts, or temporary control measures, such as no-burn days, and (3) identification of diurnal variations or variations due to temporary, sitespecific activities.

For the NonRadNET study, continuous $\mathrm{PM}_{10}$ and $\mathrm{PM}_{2.5}$ concentrations in micrograms per cubic meter $\left(\mu \mathrm{g} / \mathrm{m}^{3}\right)$ were collected using a Rupprecht \& Patashnick tapered element oscillating microbalance (TEOM) Series 1400a ambient particulate monitor fitted with either $\mathrm{PM}_{10}$ or $\mathrm{PM}_{2.5}$ sample inlets. Figure 4-1 shows a photograph of the TEOM sampling equipment inside an enclosure at Site \#61 near the medical center.

The Rupprecht and Patashnick TEOM has been designated a Federal Equivalent Method by the EPA for compliance monitoring. The TEOM draws air through a hollow tapered tube, with the wide end 
of the tube fixed, while the narrow end oscillates in response to an applied electric field. The narrow end of the tube holds a filter cartridge. The sampled air stream passes from the sampling inlet, through the filter and tube, to a flow controller. As particles are collected on the filter, the oscillating mass changes and results in a change in the oscillating frequency. An electronic control system maintains the tapered tube in oscillation and continuously measures the oscillating frequency and its changes. The resonant frequency of the element decreases as mass accumulates on the filter. Temperatures must be maintained at a fairly constant value, typically $50^{\circ} \mathrm{C}$, to minimize thermal expansion of the tapered element.

In the NonRadNET study, the collecting instruments automatically recorded and electronically saved the $\mathrm{PM}_{10 / 2.5}$ data for subsequent downloading and transfer to a database maintained by MAQ. These data were used as an indicator of natural dust loading in the atmosphere and to aid in interpreting the inorganic elemental concentration data determined on the large TSP filters.

The data from these TEOMs provide good short-term measurements that can be used to make decisions about protecting sensitive individuals from exposure to high levels of particulate matter. For example, during the 2002 Arizona wildfires these monitors were used to advise New Mexico Department of Health officials about the levels of smoke in the atmosphere.

\subsection{Volatile Organic Compound Sampling/Analysis Procedures}

A ThermoAnderson ${ }^{\circledR}$ Ambient Volatile Organic Collection System was used to collect samples of ambient air in 15-liter Summa canisters owned by LANL. Figure 4-2 shows the sampling equipment for this system at Site \#61 near the medical center. Prior to each sampling event, all canisters were pre-cleaned and monitored for residual levels of all VOC to be determined by Severn-Trent Laboratories (STL), located in Austin, TX. Upon completion of an integrated 24-hour sample, taken simultaneously at all sites every twelfth day per EPA procedure, all canisters were returned to STL under chain of custody for VOC determination via EPA Compendium Method TO-15. Up to 160 organic compounds were reported for each sample and these data were stored within the existing AIRNET database for subsequent evaluation and interpretation.

Field sampling data were entered manually on paper forms and returned to MAQ for keyboard entry into an existing database. Net air volumes sampled were calculated using calibration procedures provided by each sampling system's manufacturer. These volumes were used to calculate net ambient air concentrations of TSP, VOC, and inorganic elements.

\subsection{Data Management and Quality Assurance}

The NonRadNET project was operated according to a formal quality assurance project plan [LANL2002a]. This plan and related procedures describe or prescribe all of the planned and systematic activities believed necessary to provide adequate confidence that NonRadNET processes perform satisfactorily. Current copies of these documents are available on the web at www.airquality.lanl.gov.

The following subsections briefly describe the NonRadNET data management and quality program. 


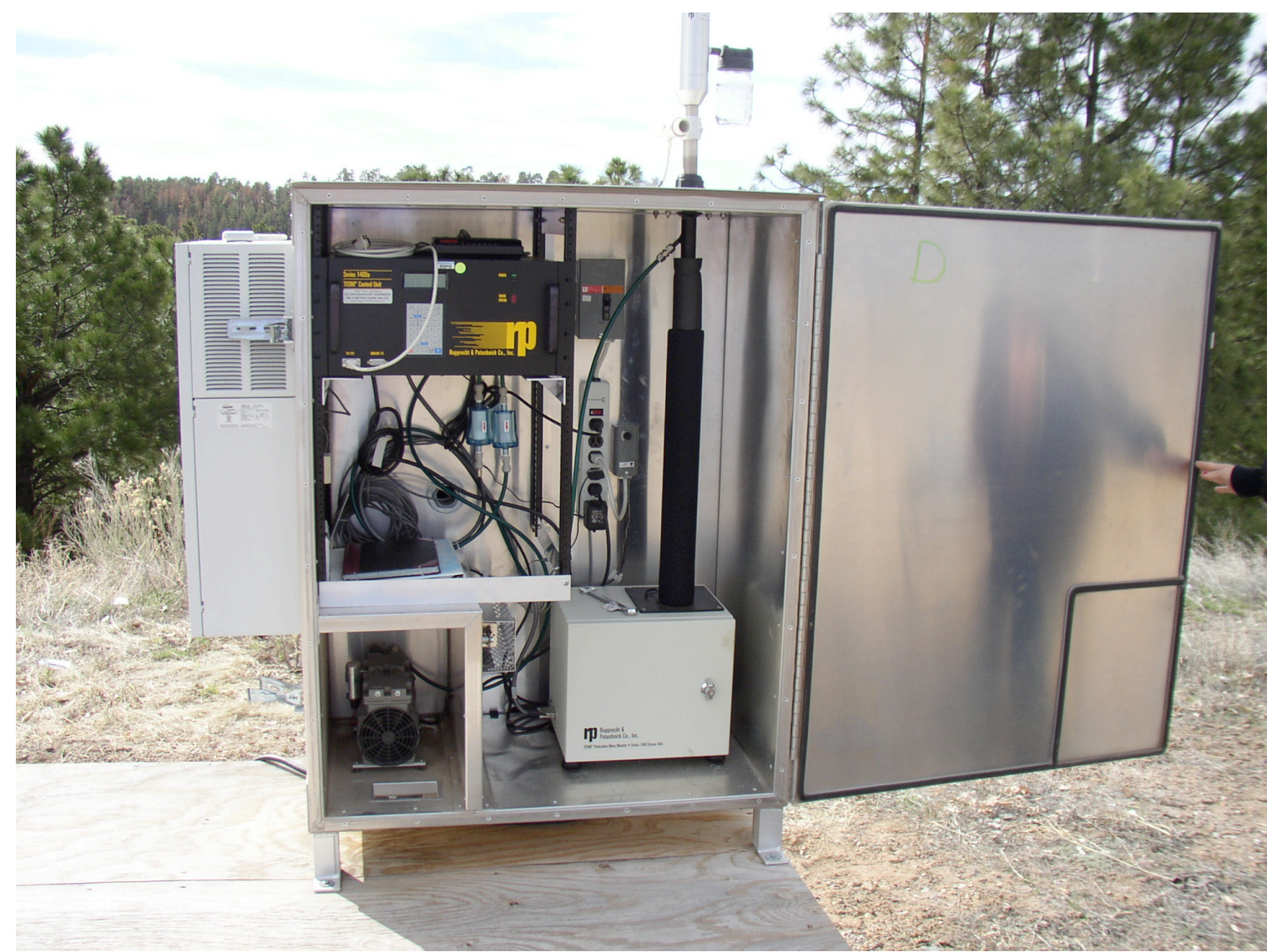

Figure 4-1. TEOM sampling equipment inside an enclosure at Site \#61.

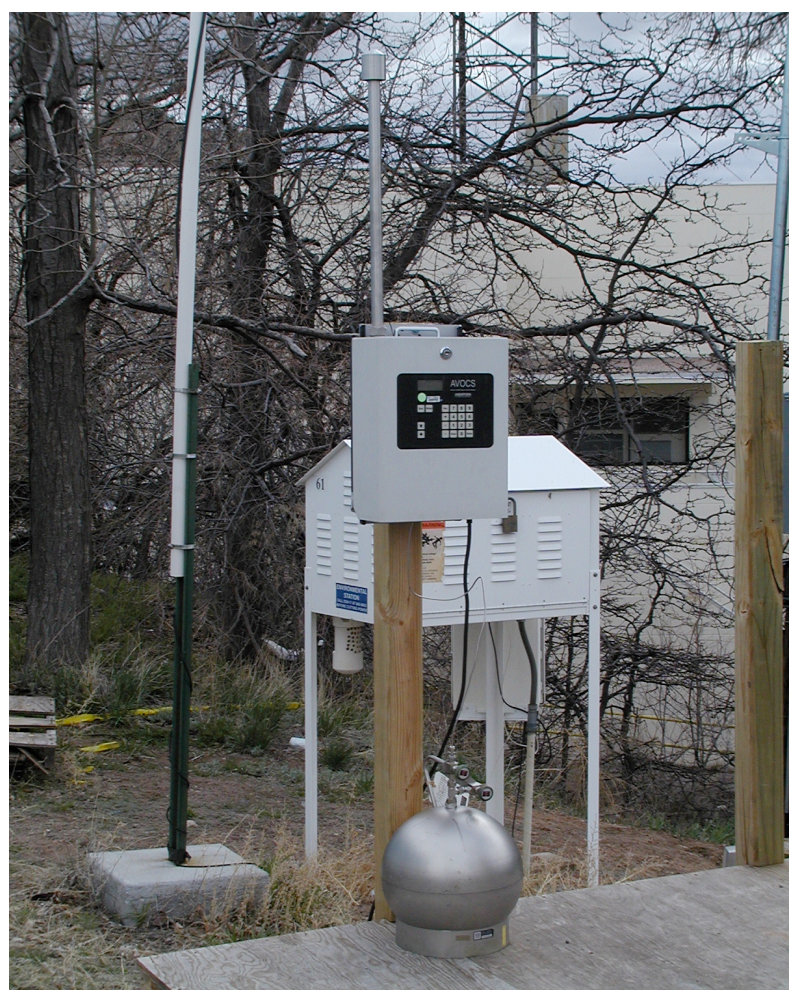

Figure 4-2. Ambient Volatile Organic Collection System at Site \#61. 


\subsubsection{Field Sampling Quality Assurance}

Overall quality of this portion of the program was maintained through the rigorous use of carefully documented procedures governing all aspects of the sample collection program. Particulate samples were taken on commercially available media of known performance. VOC samples were collected in Summa canisters of known characteristics. All samples were collected under common EPA chain-of-custody procedures using field-portable electronic data systems to minimize the chances of data transcription errors. These samples were prepared for shipment in a secure, clean laboratory. Samples were shipped to external analytical laboratories under full chain of custody by a secure commercial shipper. MAQ tracked samples at all stages of their collection and analysis through the AIRNET relational database. A complete suite of blanks was also included for analysis with each set of samples. These blanks consisted of matrix blanks, trip blanks, and process blanks (where applicable).

Field sampling completeness was determined each sampling period upon receipt of the inorganic or VOC analytical data sets. Chemistry staff in MAQ included all of these calculations in quality assessment memos that were prepared to evaluate every data set received from an analytical laboratory.

\subsubsection{Analytical Laboratory Quality Assessment}

Specific Statements of Work (SOWs) were written to govern the acquisition and delivery of analytical chemistry services after the Data Quality Objective (DQO) process had identified and quantified our program objectives. These SOWs were sent to potentially qualified suppliers who then underwent pre-award on-site assessment by experienced and trained MAQ quality systems and chemistry laboratory assessors. SOW specifications, professional judgment, and quality system performance at each laboratory (including recent past performance on nationally conducted performance evaluation programs) were primarily used to award contracts for specific types of analyses.

Each laboratory conducted its chain-of-custody and analytical processes under their own quality plans and analytical procedures. Preliminary data were returned to MAQ via e-mail in an electronic data deliverable of specified format and content. Each set of samples contained all of the internal quality assurance/quality control data generated by the analytical laboratory during each phase of analysis. These quality assurance/quality control data included laboratory control standards (LCS), VOC surrogate compounds, process blanks, matrix spikes, duplicates, and replicates, where applicable. All data were electronically uploaded into the AIRNET database and immediately subjected to a variety of quality and consistency checks. Analytical completeness was calculated, and tracking and trending of all blank and control sample data were performed. All results were included in the quality assessment memo mentioned in the field sampling section. All parts of the data management process were tracked electronically, and periodic reports to management were prepared.

\subsubsection{Evaluation of Field and Analytical Data Quality Control Results}

Field data completeness for NonRadNET was 100\%. Sampler run time was greater than $95 \%$ at each station. Analytical data completeness was $100 \%$ for samples submitted to analytical 
laboratories. The Clean Air Act required that an EPA-compliant program of quality control samples be included as an integral part of the sampling and analysis process. Our sample and data management procedures documented the specific evaluations of each type of quality control sample for each analytical measurement. These quality control parameters were tracked and trended as the analytical results were returned from the laboratories. The overall results of this quality program are summarized in the tables in this section.

The analytical laboratory corrected all VOC data for instrument and canister blanks during the gas chromatography/mass spectrometry analysis of the gas recovered from the Summa canisters. Five EPA-specified surrogate compounds, used as indicators of analytical recovery, were added to each analytical sample prior to injection into the spectrometer. EPA considers that VOC surrogate recoveries within the range of $70 \%$ to $130 \%$ are an indication that the instrument measurement process is under control. The analytical laboratory maintained an excellent surrogate recovery record during the entire program as summarized in Table 4-1.

Table 4-1. VOC Surrogate Recovery Summary for 2001-2002

\begin{tabular}{|l|l|c|c|}
\hline \multicolumn{1}{|c|}{ CAS \# } & \multicolumn{1}{|c|}{$\begin{array}{c}\text { Surrogate } \\
\text { Compound Name }\end{array}$} & $\begin{array}{c}\text { Mean \% } \\
\text { Recovery }\end{array}$ & $\begin{array}{c}\text { \% Std Dev of } \\
\text { Recovery* }\end{array}$ \\
\hline $110-56-5$ & 1,4-Dichlorobutane & 93.7 & 6.7 \\
\hline $2037-26-5$ & Toluene-d8 & 103.6 & 5.6 \\
\hline $421-06-7$ & 2-Bromo-1,1,1-trifluoroethane & 94.4 & 8.5 \\
\hline $460-00-4$ & 4-Bromofluorobenzene & 98.4 & 6.2 \\
\hline $462-06-6$ & Fluorobenzene & 85.4 & 12.5 \\
\hline
\end{tabular}

*127 values for each compound

Inorganic analysis quality controls included LCS, matrix blanks, matrix spikes, and process blanks. We also monitored the reported detection limit on each sample to ensure that contract and program requirements were consistently met and compared a number of elements measured by both analytical methods throughout the whole sampling program.

The LCS was a single aqueous solution containing known quantities of all elements of interest. The LCS was analyzed at the beginning of each analytical measurement session. This performance check was intended to alert the analyst to potential instrument problems at the outset of each sample set. The summarized results for both ICPES and ICPMS are shown in Table 4-2. We considered recoveries of $100 \pm 10 \%$ of the known value with a standard deviation of $<10 \%$ to represent excellent control. The vast majority of the data shown in Table 4-2 meet this criterion with only a few exceptions. Chromium $(\mathrm{Cr})$ recoveries by both analytical methods remained slightly on the high side with a larger standard deviation than desirable during the entire program. Iron (Fe) evidenced out of control conditions during the first half of the program, as can be seen by its very high mean recovery and large standard deviation. Ultimately we conducted an on-site assessment with the analytical laboratory to correct this situation. The ICPES antimony ( $\mathrm{Sb}$ ) recovery was slightly low throughout the program, but the ICPMS Sb recovery was under good control. Ultimately, we only reported the ICPMS Sb measurements during the latter portion of the program. 
Table 4-2. LCS* Recovery Summary for Inorganics for 2001-2002

\begin{tabular}{|c|c|c|c|c|}
\hline Element & $\begin{array}{c}\text { ICPES \% } \\
\text { Recovery } \\
\text { (Mean } \pm \text { StdDev) }\end{array}$ & $\begin{array}{c}\text { ICPES } \\
\text { Measurements }\end{array}$ & $\begin{array}{c}\text { ICPMS \% } \\
\text { Recovery } \\
\text { (Mean } \pm \text { StdDev) }\end{array}$ & $\begin{array}{c}\text { CPMS } \\
\text { Measurements }\end{array}$ \\
\hline $\mathrm{Ag}$ & $93.0 \pm 3.9$ & 27 & $99.2 \pm 6.6$ & 46 \\
\hline $\mathrm{As}$ & $95.4 \pm 5.8$ & 46 & --- & --- \\
\hline $\mathrm{Ba}$ & $104.4 \pm 4.5$ & 46 & $99.3 \pm 4.6$ & 46 \\
\hline $\mathrm{Be}$ & $100.7 \pm 7.1$ & 46 & --- & 46 \\
\hline $\mathrm{Cd}$ & $102.2 \pm 6.4$ & 27 & $96.8 \pm 4.5$ & 46 \\
\hline $\mathrm{Ce}$ & $103.8 \pm 4.0$ & 23 & $98.2 \pm 3.0$ & 23 \\
\hline $\mathrm{Co}$ & $103.6 \pm 5.7$ & 27 & $102.2 \pm 7.4$ & 46 \\
\hline $\mathrm{Cr}$ & $111.3 \pm 17.5$ & 46 & $111.0 \pm 14.3$ & 46 \\
\hline $\mathrm{Cu}$ & $104.3 \pm 5.1$ & 46 & $99.4 \pm 6.4$ & 27 \\
\hline $\mathrm{Fe}$ & $165.9 \pm 84.9$ & 24 & --- & 24 \\
\hline $\mathrm{Mn}$ & $103.8 \pm 4.0$ & 28 & $104.3 \pm 8.1$ & 28 \\
\hline $\mathrm{Nd}$ & $100.1 \pm 3.6$ & 22 & $97.8 \pm 3.6$ & 23 \\
\hline $\mathrm{Ni}$ & $104.4 \pm 4.8$ & 27 & $102.0 \pm 7.3$ & 46 \\
\hline $\mathrm{Pb}$ & $108.0 \pm 9.0$ & 27 & $101.3 \pm 7.9$ & 46 \\
\hline $\mathrm{Sb}$ & $89.9 \pm 13.4$ & 27 & $96.7 \pm 9.9$ & 46 \\
\hline $\mathrm{Se}$ & $90.9 \pm 16.5$ & 46 & --- & --- \\
\hline $\mathrm{Sr}$ & $104.6 \pm 3.5$ & 28 & $99.1 \pm 6.1$ & 28 \\
\hline $\mathrm{Tl}$ & $98.8 \pm 10.0$ & 27 & $94.9 \pm 8.7$ & 46 \\
\hline $\mathrm{V}$ & $99.3 \pm 4.4$ & 46 & --- & --- \\
\hline $\mathrm{Zn}$ & $110.7 \pm 12.7$ & 46 & $103.5 \pm 5.9$ & 46 \\
\hline
\end{tabular}

*Laboratory Control Standard

Laboratory matrix spikes (LMS), single filters of the same type as samples, were analyzed in each batch of samples. The analyst spiked the LMS with differing portions of an aqueous solution containing known quantities of all elements of interest. These LMS were treated identically with the samples during sample preparation and analysis. This matrix spike was intended to alert the analyst to potential method problems that could be related either to the matrix or to something in the sample preparation process after each sample set had been run. The summarized results for both ICPES and ICPMS are shown in Table 4-3. We considered recoveries of $100 \pm 10 \%$ of the known value with a standard deviation of $<10 \%$ to represent excellent control. The vast majority of the data shown in Table 4-3 meet this criterion with only a few exceptions. As with the LCS above, chromium (Cr) recoveries in the LMS by both analytical methods remained significantly on the high side with a large standard deviation during the entire program. Iron $(\mathrm{Fe})$ evidenced out of control conditions during the first half of the program, as can be seen by the very high mean recovery and large standard deviation, similar to the situation observed in the LCS. The ICPES antimony (Sb) recovery was slightly low throughout the program while that of the ICPMS was under good control. Finally, the lead $(\mathrm{Pb})$ and zinc $(\mathrm{Zn})$ recoveries by both methods remained slightly high throughout the whole program for undetermined reasons. 
Table 4-3. LMS* Recovery Summary for Inorganics for 2001-2002

\begin{tabular}{|c|c|c|c|c|}
\hline Element & $\begin{array}{c}\text { ICPES \% } \\
\text { Recovery } \\
\text { (Mean } \pm \text { StdDev) }\end{array}$ & $\begin{array}{c}\text { ICPES } \\
\text { Measurements }\end{array}$ & $\begin{array}{c}\text { ICPMS \% } \\
\text { Recovery } \\
\text { (Mean } \pm \text { StdDev) }\end{array}$ & $\begin{array}{c}\text { ICPMS } \\
\text { Measurements }\end{array}$ \\
\hline $\mathrm{Ag}$ & $92.7 \pm 18.3$ & 20 & $100.9 \pm 7.8$ & 40 \\
\hline $\mathrm{As}$ & $95.1 \pm 4.8$ & 40 & --- & --- \\
\hline $\mathrm{Ba}$ & $102.5 \pm 5.2$ & 40 & $97.7 \pm 3.5$ & 40 \\
\hline $\mathrm{Be}$ & $103.8 \pm 6.1$ & 40 & --- & --- \\
\hline $\mathrm{Cd}$ & $102.7 \pm 4.3$ & 20 & $98.1 \pm 2.8$ & 40 \\
\hline $\mathrm{Ce}$ & $103.7 \pm 3.2$ & 18 & $99.6 \pm 3.7$ & 18 \\
\hline $\mathrm{Co}$ & $103.2 \pm 5.4$ & 20 & $99.3 \pm 8.1$ & 40 \\
\hline $\mathrm{Cr}$ & $128.4 \pm 39.5$ & 40 & $126.3 \pm 16.6$ & 20 \\
\hline $\mathrm{Cu}$ & $108.2 \pm 5.5$ & 40 & $102.5 \pm 7.4$ & 20 \\
\hline $\mathrm{Fe}$ & $158.3 \pm 51.9$ & 21 & --- & --- \\
\hline $\mathrm{Mn}$ & $103.8 \pm 4.2$ & 24 & $102.7 \pm 8.9$ & 24 \\
\hline $\mathrm{Nd}$ & $100.9 \pm 2.8$ & 17 & $99.8 \pm 3.2$ & 18 \\
\hline $\mathrm{Ni}$ & $106.5 \pm 5.7$ & 20 & $104.1 \pm 7.7$ & 40 \\
\hline $\mathrm{Pb}$ & $112.0 \pm 14.4$ & 20 & $110.6 \pm 17.5$ & 40 \\
\hline $\mathrm{Sb}$ & $81.9 \pm 11.3$ & 20 & $97.7 \pm 7.9$ & 40 \\
\hline $\mathrm{Se}$ & $97.1 \pm 9.7$ & 40 & --- & --- \\
\hline $\mathrm{Sr}$ & $103.7 \pm 3.5$ & 24 & $96.9 \pm 6.2$ & 24 \\
\hline $\mathrm{Tl}$ & $96.1 \pm 7.0$ & 20 & $94.9 \pm 7.0$ & 40 \\
\hline $\mathrm{V}$ & $99.6 \pm 4.5$ & 40 & --- & --- \\
\hline $\mathrm{Zn}$ & $110.9 \pm 9.3$ & 40 & $106.8 \pm 11.5$ & 40 \\
\hline
\end{tabular}

*Laboratory Matrix Spike

We monitored the reported detection limit on each sample to ensure that contract requirements and program DQOs were being consistently met. These results are summarized in Table 4-4. The analytical laboratory met all detection limit requirements that were contained in the original SOW. In general, ICPMS proved to be the more sensitive analytical procedure for many elements that it was able to readily measure: $\mathrm{Ag}, \mathrm{Ce}, \mathrm{Co}, \mathrm{Cr}, \mathrm{Nd}, \mathrm{Ni}, \mathrm{Pb}, \mathrm{Sb}, \mathrm{Tl}$, and $\mathrm{Zn}$. Interestingly, ICPES proved to have modestly superior sensitivity for $\mathrm{Ba}, \mathrm{Cd}, \mathrm{Cu}, \mathrm{Mn}$, and $\mathrm{Sr}$.

We also compared results for a number of elements measured by both analytical methods throughout the whole sampling program. This comparison is shown in Table 4-5, was calculated as the individual ratios of ICPES data to ICPMS data, and then reported as the mean and standard deviation of these individual ratios by element. For most elements the methods delivered very comparable data. 
Table 4-4. Detection Limit Summary for Inorganics for 2001-2002

\begin{tabular}{|c|c|c|c|c|}
\hline Element & $\begin{array}{c}\text { ICPES } \\
\text { Mean } \\
\text { (ng/sample) }\end{array}$ & $\begin{array}{c}\text { ICPES } \\
\text { Measurements }\end{array}$ & $\begin{array}{c}\text { ICPMS } \\
\text { Mean } \\
\text { (ng/sample) }\end{array}$ & $\begin{array}{c}\text { ICPMS } \\
\text { Measurements }\end{array}$ \\
\hline $\mathrm{Ag}$ & 24 & 156 & 6.5 & 276 \\
\hline $\mathrm{As}$ & 75 & 276 & --- & --- \\
\hline $\mathrm{Ba}$ & 21 & 276 & 19 & 276 \\
\hline $\mathrm{Be}$ & 5.2 & 276 & --- & --- \\
\hline $\mathrm{Cd}$ & 5.0 & 156 & 8.4 & 146 \\
\hline $\mathrm{Ce}$ & 107 & 148 & 7.4 & 276 \\
\hline $\mathrm{Co}$ & 65 & 156 & 7.1 & 156 \\
\hline $\mathrm{Cr}$ & 35 & 276 & 20 & 156 \\
\hline $\mathrm{Cu}$ & 33 & 276 & 44 & --- \\
\hline $\mathrm{Fe}$ & 106 & 166 & --- & 184 \\
\hline $\mathrm{Mn}$ & 5.0 & 184 & 18 & 276 \\
\hline $\mathrm{Nd}$ & 48 & 142 & 7.4 & 276 \\
\hline $\mathrm{Ni}$ & 45 & 156 & 11 & 276 \\
\hline $\mathrm{Pb}$ & 29 & 156 & 6.6 & --- \\
\hline $\mathrm{Sb}$ & 25 & 156 & 10 & 184 \\
\hline $\mathrm{Se}$ & 138 & 276 & --- & 276 \\
\hline $\mathrm{Sr}$ & 5.2 & 184 & 9.6 & --- \\
\hline $\mathrm{Tl}$ & 57 & 157 & 6.3 & 276 \\
\hline $\mathrm{V}$ & 17 & 276 & --- & 28 \\
\hline $\mathrm{Zn}$ & 93 & 276 & & \\
\hline
\end{tabular}

\subsubsection{Analytical Laboratory Assessments}

MAQ conducted formal supplier assessments at each external laboratory performing chemical analyses reported for NonRadNET samples. All of these analytical laboratories also participated in national performance evaluation studies during 2001-2002. The detailed results of these performance evaluations are included in each assessment report [Gladney2001, Morgan, and Gladney2003]. Overall the analytical laboratories that participated in these national studies were judged by the study sponsors to have acceptable performance for almost all analytes attempted in all matrices. 
Table 4-5. Comparison of ICPES and ICPMS Concentration Results

\begin{tabular}{|c|c|c|}
\hline Element & $\begin{array}{c}\text { ICPES/ICPMS Ratio } \\
\text { (Mean } \pm \text { Std Dev) }\end{array}$ & Measurements \\
\hline $\mathrm{Ag}$ & $2.7 \pm 0.8$ & 44 \\
\hline $\mathrm{Ba}$ & $1.03 \pm 0.07$ & 110 \\
\hline $\mathrm{Cd}$ & $1.6 \pm 0.7$ & 33 \\
\hline $\mathrm{Ce}$ & $1.02 \pm 0.07$ & 54 \\
\hline $\mathrm{Co}$ & $0.95 \pm 0.09$ & 49 \\
\hline $\mathrm{Cr}$ & $0.80 \pm 0.12$ & 50 \\
\hline $\mathrm{Cu}$ & $1.09 \pm 0.08$ & 50 \\
\hline $\mathrm{Mn}$ & $0.99 \pm 0.11$ & 72 \\
\hline $\mathrm{Nd}$ & $0.94 \pm 0.15$ & 51 \\
\hline $\mathrm{Ni}$ & $1.01 \pm 0.07$ & 50 \\
\hline $\mathrm{Pb}$ & $0.99 \pm 0.04$ & 50 \\
\hline $\mathrm{Sb}$ & $1.3 \pm 0.3$ & 47 \\
\hline $\mathrm{Sr}$ & $1.02 \pm 0.08$ & 72 \\
\hline $\mathrm{Tl}$ & $2.1 \pm 2.2$ & 10 \\
\hline $\mathrm{Zn}$ & $1.06 \pm 0.09$ & 110 \\
\hline
\end{tabular}

\subsubsection{Data Rejection}

Inconsistencies in blanks for a few elements (primarily $\mathrm{Ag}, \mathrm{Cr}, \mathrm{Fe}$, and $\mathrm{Ni}$ ) ultimately caused the rejection of some of these analytical data. In the cases where the matrix blank for an individual set of samples was so uncharacteristically high that it caused the blank-corrected net air concentration to become negative, we rejected those values from the determination of ambient conditions during this study period.

Although TSP has been routinely reported since the 1960s throughout the world, it is actually a rather difficult determination to do well. Quality control procedures are not straightforward, since the actual water and VOC content of the filter material and the sampled particles can strongly influence the accuracy of the outcome. Simply performing carefully calibrated weighing of the filter before and after sampling is far from adequate quality control to ensure results of known quality. As a result of our experience with the Dynaweb ${ }^{\circledR}$ filter material used during 2001, we ultimately rejected all of those TSP data and changed to Whatman ${ }^{\circledR} 41$ filters to better control our TSP data acquisition. During 2002 we were able to use simultaneous $\mathrm{PM}_{10}$ data as an additional check on the accuracy of our reported TSP, and did eliminate a small number of TSP results due to the TSP weight being much greater than the 24-hour $\mathrm{PM}_{10}$ average at the same station.

\subsubsection{Inorganic Uncertainty Study}

EPA Methods 6010 and 6020 do not provide for determining and reporting analytical uncertainties for inorganic elemental measurements. We made an effort to provide some basis for estimating these uncertainties by commissioning a reproducibility study for spiked samples using our filter matrices. Five replicate spikes that span the actual sample concentration range observed during this entire study were prepared at seven different concentration levels for each element. 


\subsection{Origins and Uses of Nonradioactive Species in Ambient Air}

As described in Sections 3 and 4 above, NonRadNET measured three broad categories of nonradioactive species:

- 3 particulate matter size ranges

- 20 inorganic elements

- $160 \mathrm{VOCs}$

This section discusses some of the general origins and, where applicable, typical uses of these ambient airborne species. It also labels the various measured species according to regulatory hazard classes. The intended purpose of this section is to provide some practical insight into this large number of measured species, so that they are not just long lists of strange chemical names but, rather, can better be related to our everyday living, health, and the environment. In fact, such insight will be our purpose in subsequent sections as we compare the measured species with LANL and other airborne emission sources in the area, summarize the measured concentrations of these species, compare their measured concentrations with typical national values, and compare the measured concentrations with exposure standards.

\subsection{Particulate Matter}

Particulate matter is the term for the small particles of solid or semi-solid material found in the atmosphere. Particulates ranging in size from less than 0.1 micrometer to 50 micrometers are called TSP. Particles larger than that range tend to settle out of the air. Particulate matter 10 micrometers in diameter and smaller can be inhaled. This particulate matter is commonly called $\mathrm{PM}_{10}$.

Particles larger than 10 micrometers are usually due to fugitive dust from activities such as sand and dirt blown by winds from roadways, fields, and construction sites. This naturally occurring fugitive dust contains large amounts of silica (sand like) materials. The majority of anthropogenic (humanmade) particles are in the 0.1 to 10 micrometer diameter range. These particles are generally created during a burning process and include fly ash from power plants, carbon black from automobiles and diesel engines, and soot from fire places and wood stoves. $\mathrm{PM}_{10}$ particles are typically attributable to both anthropogenic and natural sources. The $\mathrm{PM}_{10}$ particles from these sources contain a large percentage of elemental and organic carbon, which play a major role in the formation of haze and contribute to adverse health effects.

Fine particles with diameters less than 2.5 micrometers are known as $\mathrm{PM}_{2.5}$. These fine particles are primarily from combustion processes as well as particles that are formed in the atmosphere from condensation, chemical reaction, or decay of gases and vapors. Generally, they pose a greater health risk because they can deposit deep in the lungs and contain chemicals that are particularly harmful to health. In addition to health impacts, these fine particles tend to stay in the atmosphere for longer periods of time and are the main contributors to regional haze and reduced visibility.

The NonRadNET program included sampling for TSP, $\mathrm{PM}_{10}$, and $\mathrm{PM}_{2.5}$. 


\subsection{Inorganic Elements}

NonRadNET measured 20 elements (as various inorganic compounds). These elements are shown in Table 5-1. EPA classifies 10 of these elements and their compounds as Hazardous Air Pollutants (HAPs) [EPA-HAP]. Those 10 inorganic HAPs include the pure elements and compounds of

- antimony

- $\operatorname{arsenic}$

- beryllium

- cadmium

- chromium

- cobalt

- lead

- manganese

- nickel

- selenium

All 20 of the monitored elements occur naturally in the earth's crust, and most can be easily detected anywhere in the world. Besides occurring naturally in the ground and air, they are also used in a wide variety of human-made products and processes. Manufacturing and using these products can enhance the presence of these elements in air. Mining the ores of these elements and natural weathering of ore-bearing rock also contribute to airborne emissions of these elements. Table 5-1 provides a summary of some of the human-made sources and uses of these elemental materials. In addition to the uses listed below, trace amounts of arsenic, chromium, manganese, nickel, and lead may be present in vehicle exhausts.

This information was extracted from web sites of the Agency for Toxic Substances and Disease Registry (ATSDR) [ATSDR-TPIS], EPA [EPA-HENHAP], and the WebElements Periodic Table [Winter]. See those web sites for more technical information on these elements, their natural and human-made emission sources, and health effects.

\subsection{Volatile Organic Compounds}

NonRadNET monitored the ambient air for approximately 160 VOCs. For complete alphabetical and CAS-ordered lists of these VOCs, see Appendix A. Because of the large number of VOCs involved, it is helpful to divide them into manageable groups by source and use. We have chosen to group the VOCs by the following source/use categories:

- Naturally occurring materials

- Mobile fuel and exhaust combustion products

- Tobacco combustion products

- Refrigerants

- Solvents

- Miscellaneous VOCs 
Table 5-1. Human-Made Sources/Uses of NonRadNET Inorganic Elements

\begin{tabular}{|l|c|l|}
\hline \multicolumn{1}{|c|}{ Name } & Symbol & \multicolumn{1}{c|}{ Human-Made Uses* } \\
\hline Antimony & $\mathrm{Sb}$ & Metal hardening processes, lead-acid batteries, fire retardant \\
\hline Arsenic & $\mathrm{As}$ & Pressure treated lumber (90\% of all use), copper/lead smelting, pesticides \\
\hline Barium & $\mathrm{Ba}$ & Oil/gas dril ling, paint, brick/ceramic/tile, rubber, medical procedures \\
\hline Beryllium & $\mathrm{Be}$ & Metal alloys (electrical, cars, golf clubs), nuclear weapons, mirrors, fuels \\
\hline Cadmium & $\mathrm{Cd}$ & Batteries, pigments, metal coatings, byproduct of zinc/lead/copper smelting \\
\hline Cerium & $\mathrm{Ce}$ & Metal alloys, gas lantern mantles, self-cleaning oven surfaces, diesel \\
\hline Chromium & $\mathrm{Cr}$ & Steel alloy, electroplating, dyes, leather/wood preservation, copy machine toner \\
\hline Cobalt & $\mathrm{Co}$ & Metal alloys (grinding tools, artificial joints), vitamin B12, colorant \\
\hline Copper & $\mathrm{Cu}$ & Coins, wiring, water pipe, wood preservative, leather, fabrics, colorant \\
\hline Iron & $\mathrm{Fe}$ & Most commonly used metal \\
\hline Lead & $\mathrm{Pb}$ & Mostly in lead-acid batteries and ammunition, no longer in gasoline/paint \\
\hline Manganese & $\mathrm{Mn}$ & Metal alloys, batteries, matches, fireworks, gasoline, diesel, pesticides \\
\hline Neodymium & $\mathrm{Nd}$ & Metal alloys, magnets, and as a colorant in glass and paint \\
\hline Nickel & $\mathrm{Ni}$ & Electroplating, batteries, coins, stainless steel, high-resistance wire, spark plugs \\
\hline Selenium & $\mathrm{Se}$ & Burning coal, dandruff shampoo, animal food additive, gun bluing \\
\hline Silver & $\mathrm{Ag}$ & Photographic film and processing, coins, jewelry, flatware, medicine/dentistry \\
\hline Strontium & $\mathrm{Sr}$ & Colorant in fireworks, color television tubes, zinc refining \\
\hline Thallium & $\mathrm{Tl}$ & Burning coal, cement factories, smelting, cigarettes, electronics, medical \\
\hline Vanadium & $\mathrm{V}$ & Burning coal/fuel oil, steel making \\
\hline Zinc & $\mathrm{Zn}$ & Metal corrosion inhibitor, coins, paint, rubber, sun block, deodorant, shampoo \\
\hline
\end{tabular}

Some VOCs will appear in more than one group. However, no attempt has been made to exhaustively determine all origins or uses of all species. Instead, the information is intended to provide a general perspective of the more common uses and sources of these materials.

Besides grouping the compounds by origin and uses, those that are classified as one or more of the following hazard categories are also identified:

- $\quad$ EPA 188 HAPs [EPA-HAP],

- 33 National Air Toxics Assessment (NATA) Pollutants (a subset of HAPs) [EPA-NATA],

- Photochemical Assessment Monitoring Station (PAMS) pollutants [EPA-PAMS]

\subsubsection{Naturally Occurring Components}

Of the approximately 160 VOCs monitored at LANL, 30 are known to exist naturally. These naturally occurring VOCs are identified and discussed at web sites of the ATSDR [ATSDR-TPIS], EPA [EPA-HENHAP], and California Air Resources Board [CARB]. Furthermore, a large fraction of the technical information in this entire Section 5.3 comes from these same three references. To be listed in this "naturally occurring" group, the VOC must be generated by one of the following (or closely related) processes:

- Living plant or animal biological activities 
- Biomass decomposition

- Ocean/geochemistry

- Forest fires

- Volcanoes

We decided that compounds existing naturally, only as a component of crude oil or natural gas, would not be considered here to be "naturally occurring," although, technically, they are. Table 5-2 lists those NonRadNET VOCs that are classed as "natural."

We do not intend to discuss every one of these naturally occurring VOCs in any detail. However, it is useful to group some of them into their common natural sources. For example some plants, foods, and fruits contain and may, at some point, emit

$\begin{array}{ll}\text { Benzaldehyde } & \text { beta-pinene } \\ \text { 4-methyl-2-pentanone } & \text { acetone } \\ \text { cyclohexane } & \text { chloroform } \\ \text { n-nonane } & \text { ethylene } \\ \text { limonene } & \text { acetaldehyde } \\ \text { ethanol } & \text { isoprene } \\ \text { alpha-pinene } & \text { isopropylbenzene }\end{array}$

Many of these VOCs are also biomass fermentation and decomposition products.

Forest fires and/or volcanoes emit

$\begin{array}{ll}1,3 \text { butadiene } & \text { acetone } \\ \text { mixed xylenes } & \text { benzene } \\ \text { toluene } & \text { methyl chloride } \\ \text { cyclohexane } & \text { methyl ethyl ketone } \\ \text { ethanol } & \text { naphthalene }\end{array}$

Marine organisms and ocean chemistry emit

ethylene dibromide

bromomethane

methyl chloride (about $99 \%$ natural)

bromoform (Marine algae is a major source.)

Ethanol (grain alcohol) is one of the most commonly detected natural VOCs in the air. In this study, it was detected at the highest average concentration $\left(23 \mu \mathrm{g} / \mathrm{m}^{3}\right)$ of any of the 160 VOCs. Other natural VOCs (acetaldehyde, acetone, and methanol) are closely associated with natural ethanol chemistry and also were detected by NonRadNET at average levels in the range of 8 to $12 \mu \mathrm{g} / \mathrm{m}^{3}$. The other naturally occurring VOCs above are typically detected at average levels of $1 \mu \mathrm{g} / \mathrm{m}^{3}$ or less. (See Section 7 for a detailed listing of average NonRadNET concentrations.)

Many of these naturally occurring VOCs are also included and discussed in the other classifications in the following subsections. 
Table 5-2. NonRadNET Naturally Occurring VOCs

\begin{tabular}{|c|c|c|c|c|}
\hline CAS \# & Name & HAPs* & $\mathbf{3 3}^{\#}$ & PAMS $^{+}$ \\
\hline $100-52-7$ & Benzaldehyde & & & \\
\hline $106-42-3$ & p-Xylene & $\mathrm{X}$ & & $\mathrm{X}$ \\
\hline $106-93-4$ & Ethylene Dibromide (1,2-Dibromoethane) & $\mathrm{X}$ & $\mathrm{X}$ & \\
\hline $106-99-0$ & 1,3-Butadiene & $\mathrm{X}$ & $\mathrm{X}$ & \\
\hline $108-10-1$ & 4-Methyl-2-pentanone (Methyl isobutyl ketone) & $\mathrm{X}$ & & \\
\hline $108-38-3$ & m-Xylene & $\mathrm{X}$ & & $\mathrm{X}$ \\
\hline $108-88-3$ & Toluene & $\mathrm{X}$ & & $\mathrm{X}$ \\
\hline $110-82-7$ & Cyclohexane & & & $\mathrm{X}$ \\
\hline $111-84-2$ & n-Nonane & & & $\mathrm{X}$ \\
\hline $123-72-8$ & Butyraldehyde & & & \\
\hline $127-91-3$ & beta-Pinene & & & \\
\hline $138-86-3$ & Limonene & & & \\
\hline $64-17-5$ & Ethanol (Ethyl Alcohol) & & & \\
\hline $67-56-1$ & Methanol (Methyl alcohol) & $\mathrm{X}$ & & \\
\hline $67-64-1$ & Acetone (2-Propanone) & & & $\mathrm{X}$ \\
\hline $67-66-3$ & Chloroform & $\mathrm{X}$ & $\mathrm{X}$ & \\
\hline $71-36-3$ & 1-Butanol & & & \\
\hline $71-43-2$ & Benzene & $\mathrm{X}$ & $\mathrm{X}$ & $\mathrm{X}$ \\
\hline $74-83-9$ & Bromomethane (Methyl Bromide) & $\mathrm{X}$ & & \\
\hline $74-85-1$ & Ethylene & & & $\mathrm{X}$ \\
\hline $74-87-3$ & Freon 40 Chloromethane (Methyl Chloride) & $\mathrm{X}$ & & \\
\hline $75-05-8$ & Acetonitrile & $\mathrm{X}$ & & \\
\hline $75-07-0$ & Acetaldehyde & $\mathrm{X}$ & $\mathrm{X}$ & $\mathrm{X}$ \\
\hline $75-25-2$ & Bromoform & $\mathrm{X}$ & & \\
\hline $78-79-5$ & Isoprene & & & $\mathrm{X}$ \\
\hline $78-93-3$ & 2-Butanone (Methyl Ethyl Ketone) & $\mathrm{X}$ & & \\
\hline $80-56-8$ & alpha-Pinene & & & \\
\hline $91-20-3$ & Naphthalene & $\mathrm{X}$ & $\mathrm{X}$ & \\
\hline $95-47-6$ & o-Xylene & $X$ & & $X$ \\
\hline $98-82-8$ & Isopropylbenzene (Cumene) & $\mathrm{X}$ & & $\mathrm{X}$ \\
\hline
\end{tabular}

\subsubsection{Mobile Fuel and Exhaust Components}

Gasoline and diesel fuels are, by far, the most used fuels in automobiles and trucks. Jet aircraft use kerosene and other jet fuels (JP-4, JP-8). Of the approximately 160 VOCs monitored at LANL, over 80 are either a component of these fuels, found in the exhaust of these fuels, or found in both the fuel and the exhaust. Table 5-3 provides a list of these VOCs and identifies whether they come from vehicle fuels, their exhaust, or both. Seventeen of these fuel/exhaust components are also naturally occurring. However, for some of these VOCs (given in the bulleted list below), the EPA [EPA2000] estimates that the majority, or a large fraction of the ambient airborne concentrations, are from vehicle emissions. 
- ethyl benzene

- styrene

- m, p, o xylene

- 1,3 butadiene

- toluene

- hexane

- methyl tert butyl ether

- benzene

- acetaldehyde

The last column in Table 5-3 gives the EPA estimated percentage of total airborne emissions for these large vehicle fuel emissions.

Table 5-3. NonRadNET Mobile Fuel and Exhaust Components

\begin{tabular}{|c|c|c|c|c|c|c|c|}
\hline CAS \# & Name & HAPs ${ }^{*}$ & $3^{\#}$ & PAMS $^{+}$ & Fuel & Exhaust & $\begin{array}{l}\text { \% Mobile } \\
\text { Emissions } \\
\end{array}$ \\
\hline $100-41-4$ & Ethyl Benzene & $X$ & & $\mathrm{X}$ & $\mathrm{X}$ & $\mathrm{X}$ & 84 \\
\hline $100-42-5$ & Styrene & $X$ & & $X$ & & $\mathrm{X}$ & 40 \\
\hline $103-65-1$ & n-Propylbenzene & & & $\mathrm{X}$ & $\mathrm{X}$ & $\mathrm{X}$ & \\
\hline $104-51-8$ & n-Butylbenzene & & & & $\mathrm{X}$ & & \\
\hline $105-05-5$ & 1,4-Diethylbenzene ( $\mathrm{p}$-Diethylbenzene) & & & $\mathrm{X}$ & $X$ & & \\
\hline $106-42-3$ & p-Xylene & $\mathrm{X}$ & & $\mathrm{X}$ & $\mathrm{X}$ & $\mathrm{X}$ & 79 \\
\hline $106-93-4$ & Ethylene Dibromide (1,2-Dibromoethane) & $\mathrm{X}$ & $\mathrm{X}$ & & $\mathrm{X}$ & & \\
\hline $106-97-8$ & Butane & & & $\mathrm{X}$ & $\mathrm{X}$ & & \\
\hline $106-99-0$ & 1,3-Butadiene & $\mathrm{X}$ & $\mathrm{X}$ & & & $\mathrm{X}$ & 60 \\
\hline $107-06-2$ & 1, 2-Dichloroethane (Ethylene Dichloride) & $\mathrm{X}$ & & & $\mathrm{X}$ & & \\
\hline $107-13-1$ & Acrylonitrile & $\mathrm{X}$ & $\mathrm{X}$ & & & $\mathrm{X}$ & \\
\hline $107-83-5$ & Isohexane (2-Methylpentane) & & & $\mathrm{X}$ & $\mathrm{X}$ & & \\
\hline $108-08-7$ & 2,4-Dimethylpentane & & & $\mathrm{X}$ & $\mathrm{X}$ & & \\
\hline $108-38-3$ & m-Xylene & $\mathrm{X}$ & & $\mathrm{X}$ & $\mathrm{X}$ & $\mathrm{X}$ & 79 \\
\hline $108-67-8$ & 1,3,5-Trimethylbenzene & & & $\mathrm{X}$ & $\mathrm{X}$ & & \\
\hline $108-87-2$ & Methylcyclohexane & & & $\mathrm{X}$ & $\mathrm{X}$ & & \\
\hline $108-88-3$ & Toluene & $\mathrm{X}$ & & $\mathrm{X}$ & $\mathrm{X}$ & $\mathrm{X}$ & 74 \\
\hline $109-66-0$ & Pentane & & & $\mathrm{X}$ & $\mathrm{X}$ & & \\
\hline $109-67-1$ & 1-Pentene & & & $\mathrm{X}$ & $\mathrm{X}$ & & \\
\hline $110-54-3$ & Hexane & $\mathrm{X}$ & & $\mathrm{X}$ & $\mathrm{X}$ & $\mathrm{X}$ & 44 \\
\hline $110-82-7$ & Cyclohexane & & & $\mathrm{X}$ & $\mathrm{X}$ & & \\
\hline $110-83-8$ & Cyclohexene & & & & $\mathrm{X}$ & & \\
\hline $111-65-9$ & n-Octane & & & $\mathrm{X}$ & $\mathrm{X}$ & & \\
\hline $111-84-2$ & n-Nonane & & & $\mathrm{X}$ & $\mathrm{X}$ & & \\
\hline $1120-21-4$ & n-Undecane & & & $\mathrm{X}$ & $\mathrm{X}$ & & \\
\hline $124-18-5$ & n-Decane & & & $\mathrm{X}$ & $\mathrm{X}$ & & \\
\hline $141-93-5$ & 1,3-Diethylbenzene (m-Diethylbenzene) & & & $\mathrm{X}$ & $\mathrm{X}$ & & \\
\hline $142-29-0$ & Cyclopentene & & & & $\mathrm{X}$ & & \\
\hline $142-82-5$ & Heptane & & & $\mathrm{X}$ & $\mathrm{X}$ & & \\
\hline
\end{tabular}

HAPs-EPA Hazardous Air Pollutant

\#33-NATA 33 Monitored Pollutants

${ }^{+}$PAMS—Photochemical Assessment Monitoring Station Pollutant 
Table 5-3 (cont.)

\begin{tabular}{|c|c|c|c|c|c|c|c|}
\hline CAS \# & Name & HAPs ${ }^{*}$ & $3^{\#}$ & $\mathbf{P A M S}^{+}$ & Fuel & Exhaust & $\begin{array}{l}\text { \% Mobile } \\
\text { Emissions }\end{array}$ \\
\hline $14686-13-6$ & trans-2-Heptene & & & & $\mathrm{X}$ & & \\
\hline 1634-04-4 & Methyl tert-Butyl Ether & $\mathrm{X}$ & & & $\mathrm{X}$ & $\mathrm{X}$ & 86 \\
\hline $287-92-3$ & Cyclopentane & & & $\mathrm{X}$ & $\mathrm{X}$ & & \\
\hline $31394-54-4$ & Isoheptane (2-Methylhexane) & & & $\mathrm{X}$ & $\mathrm{X}$ & & \\
\hline $3522-94-9$ & 2,2,5-Trimethylhexane & & & & $\mathrm{X}$ & & \\
\hline $4050-45-7$ & trans-2-Hexene & & & & $\mathrm{X}$ & & \\
\hline $463-82-1$ & Neopentane & & & & $\mathrm{X}$ & & \\
\hline 496-11-7 & Indan & & & & $\mathrm{X}$ & & \\
\hline $513-35-9$ & 2-Methyl-2-butene & & & & $\mathrm{X}$ & & \\
\hline $526-73-8$ & 1,2,3-Trimethylbenzene & & & $\mathrm{X}$ & $\mathrm{X}$ & & \\
\hline $538-93-2$ & Isobutylbenzene & & & & $\mathrm{X}$ & & \\
\hline $540-84-1$ & 2,2,4-Trimethylpentane (Isooctane) & $\mathrm{X}$ & & $\mathrm{X}$ & $\mathrm{X}$ & $\mathrm{X}$ & \\
\hline $563-45-1$ & 3-Methyl-1-butene & & & & $\mathrm{X}$ & & \\
\hline $564-02-3$ & 2,2,3-Trimethylpentane & & & & $\mathrm{X}$ & & \\
\hline $565-59-3$ & 2,3-Dimethylpentane & & & $\mathrm{X}$ & $\mathrm{X}$ & & \\
\hline $565-75-3$ & 2,3,4-Trimethylpentane & & & $\mathrm{X}$ & $\mathrm{X}$ & & \\
\hline $589-34-4$ & 3-Methylhexane & & & $\mathrm{X}$ & $\mathrm{X}$ & & \\
\hline $589-81-1$ & 3-Methylheptane & & & $\mathrm{X}$ & $\mathrm{X}$ & & \\
\hline $590-18-1$ & cis-2-Butene & & & $\mathrm{X}$ & $\mathrm{X}$ & & \\
\hline $592-27-8$ & 2-Methylheptane & & & $\mathrm{X}$ & $\mathrm{X}$ & & \\
\hline $592-41-6$ & 1-Hexene & & & & $\mathrm{X}$ & & \\
\hline 611-14-3 & 2-Ethyltoluene (o-Ethyltoluene) & & & $\mathrm{X}$ & $\mathrm{X}$ & & \\
\hline $620-14-4$ & 3-Ethyltoluene (m-Ethyltoluene) & & & $\mathrm{X}$ & $\mathrm{X}$ & & \\
\hline $622-96-8$ & 4-Ethyltoluene (p-Ethyltoluene) & & & $\mathrm{X}$ & $X$ & & \\
\hline $624-64-6$ & trans-2-Butene & & & $\mathrm{X}$ & $\mathrm{X}$ & & \\
\hline $625-27-4$ & 2-Methyl-2-pentene & & & & $\mathrm{X}$ & & \\
\hline $627-20-3$ & cis-2-Pentene & & & $\mathrm{X}$ & $\mathrm{X}$ & & \\
\hline $64-17-5$ & Ethanol (Ethyl alcohol) & & & & $\mathrm{X}$ & & \\
\hline 646-04-8 & trans-2-Pentene & & & $\mathrm{X}$ & $\mathrm{X}$ & & \\
\hline $67-56-1$ & Methanol (Methyl alcohol) & $\mathrm{X}$ & & & $\mathrm{X}$ & & \\
\hline $67-63-0$ & 2-Propanol (Isopropyl Alcohol) & & & & $\mathrm{X}$ & & \\
\hline $67-64-1$ & Acetone (2-Propanone) & & & $\mathrm{X}$ & & $\mathrm{X}$ & \\
\hline $71-43-2$ & Benzene & $\mathrm{X}$ & $\mathrm{X}$ & $\mathrm{X}$ & $\mathrm{X}$ & $\mathrm{X}$ & 76 \\
\hline $74-98-6$ & Propane & & & $\mathrm{X}$ & $\mathrm{X}$ & & \\
\hline $75-05-8$ & Acetonitrile & $\mathrm{X}$ & & & & $\mathrm{X}$ & \\
\hline $75-07-0$ & Acetaldehyde & $\mathrm{X}$ & $\mathrm{X}$ & $\mathrm{X}$ & & $\mathrm{X}$ & 70 \\
\hline $75-28-5$ & Isobutane & & & $\mathrm{X}$ & $\mathrm{X}$ & & \\
\hline $75-34-3$ & $\begin{array}{l}\text { 1,1-Dichloroethane (Ethylidene } \\
\text { Dichloride) }\end{array}$ & $\mathrm{X}$ & & & $\mathrm{X}$ & & \\
\hline $75-83-2$ & 2,2-Dimethylbutane (Neohexane) & & & $\mathrm{X}$ & $\mathrm{X}$ & & \\
\hline $760-21-4$ & 2-Ethyl-1-butene & & & & $\mathrm{X}$ & & \\
\hline $763-29-1$ & 2-Methyl-1-pentene & & & $\mathrm{X}$ & $\mathrm{X}$ & & \\
\hline 7642-09-3 & cis-3-Hexene & & & & $\mathrm{X}$ & & \\
\hline
\end{tabular}

"HAPs-EPA Hazardous Air Pollutant

"33-NATA 33 Monitored Pollutants

'PAMS—Photochemical Assessment Monitoring Station Pollutant 
Table 5-3 (cont.)

\begin{tabular}{|l|l|c|c|c|c|c|c|}
\hline \multicolumn{1}{|c|}{ CAS $\#$} & & HAPs $^{*}$ & $\mathbf{3 3}^{\#}$ & PAMS $^{+}$ & Fuel $^{\text {Exhaust }}$ & $\begin{array}{c}\text { \% Mobile } \\
\text { Emissions }\end{array}$ \\
\hline $7642-10-6$ & cis-3-Heptene & & & & $\mathrm{X}$ & & \\
\hline $7688-21-3$ & cis-2-Hexene & & & & $\mathrm{X}$ & & \\
\hline $78-78-4$ & 2-Methylbutane (Isopentane) & & & $\mathrm{X}$ & $\mathrm{X}$ & & \\
\hline $78-79-5$ & Isoprene & & & $\mathrm{X}$ & $\mathrm{X}$ & & \\
\hline $78-93-3$ & 2-Butanone (methyl Ethyl Ketone) & $\mathrm{X}$ & & & & $\mathrm{X}$ & \\
\hline $79-29-8$ & 2,3-Dimethylbutane & & & $\mathrm{X}$ & $\mathrm{X}$ & & \\
\hline $91-20-3$ & Naphthalene & $\mathrm{X}$ & $\mathrm{X}$ & & $\mathrm{X}$ & $\mathrm{X}$ & \\
\hline $95-47-6$ & o-Xylene & & & $\mathrm{X}$ & $\mathrm{X}$ & & \\
\hline $95-63-6$ & 1,2,4-Trimethylbenzene & & & $\mathrm{X}$ & $\mathrm{X}$ & & \\
\hline $96-14-0$ & 3-Methylpentane & & & $\mathrm{X}$ & $\mathrm{X}$ & & \\
\hline $96-37-7$ & Methylcyclopentane & $\mathrm{X}$ & & $\mathrm{X}$ & $\mathrm{X}$ & $\mathrm{X}$ & \\
\hline $98-82-8$ & Isopropylbenzene (Cumene) & & \\
\hline
\end{tabular}

*HAPs-EPA Hazardous Air Pollutant

\#33-NATA 33 Monitored Pollutants

${ }^{+}$PAMS - Photochemical Assessment Monitoring Station Pollutant

\subsubsection{Tobacco Smoke Products}

Because of its wide prevalence and obvious health effects, we evaluated which of the monitored VOCs are contained in tobacco smoke. Table 5-4 shows these components. All of these tobaccosmoke products, except butyraldehyde, vinyl chloride, and isoprene are also contained in vehicle exhaust. Also, all of these tobacco smoke components occur naturally, except ethyl benzene, styrene, acrylonitrile, and vinyl chloride. According to the ATSDR, even though mobile sources contribute about $76 \%$ of the ambient airborne benzene concentration, about half of the national population airborne exposure to benzene comes from tobacco smoke [ATSDR-PHSB].

Table 5-4. NonRadNET VOCs in Tobacco Smoke

\begin{tabular}{|l|l|c|c|c|}
\hline \multicolumn{1}{|c|}{ CAS } & Name & HAPs $^{*}$ & $\mathbf{3 3}^{\#}$ & PAMS $^{+}$ \\
\hline $100-41-4$ & Ethyl Benzene & $\mathrm{X}$ & & $\mathrm{X}$ \\
\hline $100-42-5$ & Styrene & $\mathrm{X}$ & & $\mathrm{X}$ \\
\hline $106-99-0$ & 1,3 -Butadiene & $\mathrm{X}$ & $\mathrm{X}$ & \\
\hline $107-13-1$ & Acrylonitrile & $\mathrm{X}$ & $\mathrm{X}$ & \\
\hline $108-88-3$ & Toluene & $\mathrm{X}$ & & $\mathrm{X}$ \\
\hline $123-72-8$ & Butyraldehyde & & & \\
\hline $67-64-1$ & Acetone (2-Propanone) & & & $\mathrm{X}$ \\
\hline $71-43-2$ & Benzene & $\mathrm{X}$ & $\mathrm{X}$ & $\mathrm{X}$ \\
\hline $75-01-4$ & Vinyl Chloride & $\mathrm{X}$ & $\mathrm{X}$ & \\
\hline $75-05-8$ & Acetonitrile & $\mathrm{X}$ & $\mathrm{X}$ & $\mathrm{X}$ \\
\hline $75-07-0$ & Acetaldehyde & & & $\mathrm{X}$ \\
\hline $78-79-5$ & Isoprene & $\mathrm{X}$ & & \\
\hline $78-93-3$ & 2-Butanone (Methyl Ethyl Ketone) & $\mathrm{X}$ & $\mathrm{X}$ & \\
\hline $91-20-3$ & Naphthalene & $\mathrm{X}$ & & $\mathrm{X}$ \\
\hline $98-82-8$ & Isopropylbenzene (Cumene) & &
\end{tabular}




\subsubsection{Refrigerants}

The NonRadNET VOCs in Table 5-5 are or have, until recently, been used as refrigerants. Note that bromomethane and methyl chloride also occur naturally.

Table 5-5. NonRadNET Refrigerants

\begin{tabular}{|c|c|c|c|c|}
\hline CAS & Name & HAPs ${ }^{*}$ & 33 $^{\#}$ & PAMS $^{+}$ \\
\hline $106-97-8$ & Butane & & & $\mathrm{X}$ \\
\hline $124-48-1$ & Dibromochloromethane & & & \\
\hline $156-59-2$ & cis-1,2 Dichloroethene & & & \\
\hline $156-60-5$ & trans-1,2-Dichloroethene & & & \\
\hline $56-23-5$ & Carbon Tetrachloride & $\mathrm{X}$ & $\mathrm{X}$ & \\
\hline $71-55-6$ & 1,1,1-Trichloroethane (Methyl Chloroform) & $\mathrm{X}$ & & \\
\hline $74-83-9$ & Bromomethane (Methyl Bromide) & $\mathrm{X}$ & & \\
\hline $74-87-3$ & Freon 40 Chloromethane (Methyl Chloride) & $\mathrm{X}$ & & \\
\hline $75-00-3$ & Chloroethane (Ethyl Chloride) Freon 160 & $\mathrm{X}$ & & \\
\hline $75-01-4$ & Vinyl Chloride & $\mathrm{X}$ & $\mathrm{X}$ & \\
\hline $75-28-5$ & Isobutane & & & $\mathrm{X}$ \\
\hline $75-43-4$ & Freon 21 (Dichlorofluoromethane) & & & \\
\hline $75-45-6$ & Freon 22 (Chlorodifluoromethane) & & & \\
\hline $75-69-4$ & Freon 11 (Trichlorofluoromethane) & & & \\
\hline $75-71-8$ & Freon 12 (Dichlorodifluoromethane) & & & \\
\hline $76-13-1$ & Freon 113 (1,1,2-Trichloro-1,2,2-trifluoroethane) & & & \\
\hline $76-14-2$ & Freon 114 (1,2-Dichlorotetrafluoroethane) & & & \\
\hline $79-01-6$ & Trichloroethene (Trichloroethylene) & $\mathrm{X}$ & & \\
\hline $811-97-2$ & Halocarbon 134A & & & \\
\hline
\end{tabular}

\subsubsection{Solvents}

Many of the components of fuels and some refrigerants are also solvents. The NonRadNET VOCs in Table 5-6 are NonRadNET solvents not found in the fuels and refrigerants tables above. Note that benzaldehyde, methyl isobutyl ketone, butyraldehyde, chloroform, and 1-butanol also occur naturally.

\subsubsection{Miscellaneous VOCs}

Some of the NonRadNET VOCs do not fit into any category above. Those VOCs are in Table 5-7. Note that, after significant research, we were unable to find any source or use information on several of these miscellaneous VOCs.

For more technical information on VOCs, their natural and human-made emission sources, and health effects, see the chemical profiles at the web sites of the ATSDR [ATSDR-TPIS], EPA [EPAHENHAP], and California Air Resources Board [CARB]. 
Table 5-6. NonRadNET Solvents

\begin{tabular}{|c|c|c|c|c|}
\hline CAS & Name & HAPs" & $\mathbf{3 3}^{\#}$ & PAMS $^{+}$ \\
\hline $100-52-7$ & Benzaldehyde & & & \\
\hline $106-43-4$ & 4-Chlorotoluene & & & \\
\hline $108-10-1$ & 4-Methyl-2-pentanone (Methyl isobutyl ketone) & $\mathrm{X}$ & & \\
\hline $108-41-8$ & 3-Chlorotoluene & & & \\
\hline $108-90-7$ & Chlorobenzene & $\mathrm{X}$ & & \\
\hline $120-82-1$ & 1,2,4-Trichlorobenzene & $\mathrm{X}$ & & \\
\hline $123-72-8$ & Butyraldehyde & & & \\
\hline $123-91-1$ & 1,4-Dioxane (1,4-Diethyloxide) & $\mathrm{X}$ & & \\
\hline $127-18-4$ & Tetrachloroethene/ethylene (Perchloroethylenehylene) & $\mathrm{X}$ & $\mathrm{X}$ & \\
\hline $60-29-7$ & Diethyl ether & & & \\
\hline $67-66-3$ & Chloroform & $\mathrm{X}$ & $\mathrm{X}$ & \\
\hline $71-36-3$ & 1-Butanol & & & \\
\hline $75-09-2$ & Methylene Chloride (Dichloromethane) & $\mathrm{X}$ & $\mathrm{X}$ & \\
\hline $75-27-4$ & Bromodichloromethane & & & \\
\hline $78-87-5$ & 1,2-Dichloropropane (Propylene Dichloride) & $\mathrm{X}$ & $\mathrm{X}$ & \\
\hline $79-00-5$ & 1,1,2-Trichloroethane & $\mathrm{X}$ & & \\
\hline $79-34-5$ & 1,1,2,2-Tetrachloroethane & $\mathrm{X}$ & $\mathrm{X}$ & \\
\hline $87-68-3$ & Hexachlorobutadiene & $\mathrm{X}$ & & \\
\hline $95-50-1$ & 1,2-Dichlorobenzene & & & \\
\hline
\end{tabular}


Table 5-7. Miscellaneous NonRadNET VOCs

\begin{tabular}{|c|c|c|c|c|c|}
\hline CAS \# & Name & HAPs" & $\mathbf{3 3}^{\#}$ & PAMS $^{+}$ & Uses \\
\hline $100-44-7$ & $\begin{array}{l}\text { Chlorotoluene (Benzyl } \\
\text { Chloride) }\end{array}$ & $\mathrm{X}$ & & & $\begin{array}{l}\text { Perfumes, dyes, flavorings, chemical } \\
\text { synthesis }\end{array}$ \\
\hline $10061-01-5$ & cis-1,3-Dichloropropene & & & & Soil fumigant \\
\hline $10061-02-6$ & trans-1,3-Dichloropropene & & & & Soil fumigant for nematodes \\
\hline $106-46-7$ & 1,4-Dichlorobenzene & $\mathrm{X}$ & & & $\begin{array}{l}\text { Insecticide/fumigant, dye, moths, } \\
\text { deodorant }\end{array}$ \\
\hline $106-98-9$ & 1-Butene & & & $\mathrm{X}$ & Organic manufacture \\
\hline $107-39-1$ & 2,4,4-Trimethyl-1-pentene & & & & \\
\hline $107-40-4$ & 2,4,4-Trimethyl-2-pentene & & & & \\
\hline $108-05-4$ & Vinyl Acetate & $\mathrm{X}$ & & & Plastics, chewing gum, hair spray \\
\hline $111-66-0$ & 1-Octene & & & & \\
\hline $111-71-7$ & Heptanal & & & & Perfumes, flavorings, drugs \\
\hline $115-07-1$ & Propylene & & & $\mathrm{X}$ & Plastic and organic manufacturing \\
\hline $124-11-8$ & 1-Nonene & & & & \\
\hline $126-99-8$ & $\begin{array}{l}\text { 2-Chloro-1,3-butadiene } \\
\text { (Chloroprene) }\end{array}$ & $\mathrm{X}$ & & & $\begin{array}{l}\text { Rubber (neoprene) manufacture, food } \\
\text { package adhesives }\end{array}$ \\
\hline $141-32-2$ & Butyl Acrylate & & & & Manufacture of polymers and resins \\
\hline $14686-14-7$ & trans-3-Heptene & & & & \\
\hline $2198-23-4$ & 4-Nonene & & & & \\
\hline $541-73-1$ & 1,3-Dichlorobenzene & & & & Fumigant and insecticide \\
\hline $591-49-1$ & 1-Methylcyclohexene & & & & \\
\hline $592-13-2$ & 2,5-Dimethylhexane & & & & \\
\hline $592-76-7$ & 1-Heptene & & & & \\
\hline $593-60-2$ & Vinyl bromide & $\mathrm{X}$ & & & Mostly a flame retardant \\
\hline $66-25-1$ & Hexanal & & & & Flame-retarding treatment for acrylics \\
\hline $691-37-2$ & 4-Methyl-1-pentene & & & & \\
\hline $691-38-3$ & cis/trans-4-Methyl-2-pentene & & & & \\
\hline $693-89-0$ & 1-Methylcyclopentene & & & & \\
\hline $71-23-8$ & 1-Propanol & & & & $\begin{array}{l}\text { Flame retardant for plastics and } \\
\text { synthetic fibers }\end{array}$ \\
\hline $74-86-2$ & Acetylene & & & $\mathrm{X}$ & Welding gas \\
\hline $74-97-5$ & Bromochloromethane & & & & $\begin{array}{l}\text { Chemical intermediate, fire } \\
\text { extinguishing }\end{array}$ \\
\hline $75-35-4$ & $\begin{array}{l}\text { 1,1-Dichloroethene (Vinylidene } \\
\text { Chloride) }\end{array}$ & $\mathrm{X}$ & & & $\begin{array}{l}\text { Used in synthetic fiber manufacture, } \\
\text { organic synthesis, and in making } \\
\text { plastic food wraps }\end{array}$ \\
\hline $7642-04-8$ & cis-2-Octene & & & & \\
\hline $821-95-4$ & 1-Undecene & & & & \\
\hline $872-05-9$ & 1-Decene & & & & \\
\hline $922-62-3$ & cis-3-Methyl-2-pentene & & & & \\
\hline $95-13-6$ & Indene & & & & Plastic resin manufacturing \\
\hline $95-49-8$ & 2-Chlorotoluene & & & & \\
\hline $98-06-6$ & tert-Butylbenzene & & & & \\
\hline $99-87-6$ & 4-Isopropyltoluene (p-Cymeme) & & & & \\
\hline
\end{tabular}

${ }^{*}$ HAPs - EPA Hazardous Air Pollutant; ${ }^{*} 33$-NATA 33 Monitored Pollutants; ${ }^{+}$PAMS—Photochemical Assessment Monitoring Station Pollutant 


\subsection{Comparison with LANL and Other Emission Sources}

This section provides an overview of the particulate matter, inorganic elements, and NonRadNET VOCs emitted by various sources in the Los Alamos area, particularly the Laboratory. No attempt has been made to fully inventory all possible sources of these materials. However, the Laboratory is required to document its use and emissions of many of the monitored species. Thus, very good emissions information, much better than for other local sources, is available for LANL.

Los Alamos has both rural and metropolitan characteristics. While the town is remote from large commercial, industrialized areas and small by national standards, traffic into and out of the town each day is relatively significant. Additionally, there are a number of commercial refueling stations, businesses of various types, large numbers of residences, and, of course, the Laboratory.

Our focus in this section is on emissions at the Laboratory related to this study, but we also consider non-Laboratory sources of such emissions. It is instructive to note that LANL is one of over 200 "major stationary sources" in New Mexico, as defined by EPA [EPA-TVPIS]. Furthermore, New Mexico has one of the lowest annual regulated airborne emissions rates of any state in the entire country [EPA-TRI].

The primary resources for determining Laboratory emissions of the 188 EPA HAPs during 2001 and 2002 were the Emissions Inventory Reports for those years [LANL2003a, LANL2003b]. For those chemicals that are not classified as HAPs, we used the 2001 and 2002 Toxic Chemicals Release Inventory Reports (also known as the Emergency Planning and Community Right-to-Know Act [EPCRA] Reports) [LANL2001, LANL2002b]. As a cross check and for those chemicals that did not fall within the criteria of the above references, we used the Laboratory Automated Chemical Inventory System (ACIS) database, which typically has about 40,000 entries of purchased chemicals each year.

\subsection{Particulate Emissions}

As stated in Section 5, significant contributors to airborne particulate matter in the air around Los Alamos include Laboratory operations, private and commercial vehicle traffic, residential fireplaces, natural wind-blown dust, plant pollens and other normal plant particulate emissions, forest fires, and, likely, other sources. The LANL Emissions Inventory Reports [LANL2003a, LANL2003b] state that LANL emitted 5.5 tons of total particulate matter in 2001 and 15.42 tons in 2002. Smaller quantities of $\mathrm{PM}_{10}$ and $\mathrm{PM}_{2.5}$ were emitted. In 2001 most of these Laboratory particulate emissions came from the Technical Area (TA) 3 steam power plant with secondary amounts from air curtain destructors used to burn wood and brush thinned from the nearby forests for fire mitigation. In 2002 the air curtain destructors contributed most of the airborne particulate emissions with secondary amounts from the TA-3 steam plant. In each case, there were also other smaller Laboratory particulate sources.

By comparison, $\mathrm{PM}_{10}$ from commuter traffic in Los Alamos County is in the range of approximately 21 tons each year. (See Appendix B for the details of this estimate.) Residential fireplaces in the area also contribute substantially to airborne particles, in the range of 29 tons/yr (Appendix B). Additionally, an unquantified, but very likely, large amount of natural wind-blown dust is emitted into the air. Regional forest fires are another obviously significant, although unquantified, source of 
airborne particles. All of these particulate sources and, no doubt, many others contribute to the airborne particulate load in the Los Alamos area. Because of the relatively small Laboratory particulate emissions, compared to all others, it would not be likely that LANL particulate emissions could easily be distinguished from other regional particulate emissions, except, perhaps, if a sampler were located very close to and downwind of a large Laboratory particulate source, such as the air curtain destructors.

\subsection{Inorganic Elements}

All of the 20 inorganic elements NonRadNET measured are present naturally in wind-blown dust. Some also occur in vehicle emissions and other combustion processes, especially coal burning, which is not a large source in the immediate area. In 2001 and 2002 [LANL2003a, LANL2003b], the Laboratory reported emissions of HAPs inorganic elements that were included in the NonRadNET program as shown in Table 6-1. The more significant chemicals (by weight) are shaded in the table. Note that these emissions are conservative estimates of actual emissions. In many cases, for conservative HAPs reporting, it was assumed that the entire inventories of these HAPs materials purchased each year were emitted in the year purchased.

Table 6-1. NonRadNET HAPs Inorganic Elements Used at LANL

\begin{tabular}{|l|c|c|c|}
\hline \multicolumn{1}{|c|}{ Element } & Symbol & 2001 Usage (tons) & 2002 Usage (tons) \\
\hline Antimony & $\mathrm{Sb}$ & 0.0 & 0.0015 \\
\hline Arsenic & $\mathrm{As}$ & 0.002 & 0.003 \\
\hline Beryllium & $\mathrm{Be}$ & $9.6 \mathrm{E}-6$ & 0.0003 \\
\hline Cadmium & $\mathrm{Cd}$ & 0.003 & 0.0007 \\
\hline Chromium & $\mathrm{Cr}$ & 0.056 & 0.021 \\
\hline Cobalt & $\mathrm{Co}$ & 0.001 & 0.003 \\
\hline Manganese & $\mathrm{Mn}$ & 0.275 & 0.844 \\
\hline Nickel & $\mathrm{Ni}$ & 0.002 & 0.038 \\
\hline Lead & $\mathrm{Pb}$ & 0.006 & 0.01 \\
\hline Selenium & $\mathrm{Se}$ & 0.0 & 0.0004 \\
\hline
\end{tabular}

The following inorganic elements are not classed as HAPs and, thus, were not reported in the emissions reports. However, if used, they were reported in the LANL ACIS databases or the EPCRA Reports for 2001 and 2002 [LANL2001, LANL2002b] in the quantities stated in Table 6-2. The more significant uses of these chemicals (by weight) are shaded in the table.

Table 6-2. Other NonRadNET Inorganic Elemental Chemicals Used at LANL

\begin{tabular}{|l|c|c|c|}
\hline \multicolumn{1}{|c|}{ Element } & Symbol & 2001 EPCRA (tons) & 2002 EPCRA (tons) \\
\hline Barium & $\mathrm{Ba}$ & 1.1 & 0.002 \\
\hline Cerium & $\mathrm{Ce}$ & 0.002 & 0.003 \\
\hline Copper & $\mathrm{Cu}$ & 0.27 & 0.08 \\
\hline Iron & $\mathrm{Fe}$ & 0.012 & 0.006 \\
\hline Neodymium & $\mathrm{Nd}$ & 0.002 & 0.0 \\
\hline Silver & $\mathrm{Ag}$ & 0.016 & 0.023 \\
\hline Strontium & $\mathrm{Sr}$ & 0.001 & 0.0 \\
\hline Thallium & $\mathrm{Tl}$ & 0.0015 & 0.0 \\
\hline Vanadium & $\mathrm{V}$ & 0.0005 & $<0.0005$ \\
\hline Zinc & $\mathrm{Zn}$ & 0.62 & 0.93 \\
\hline
\end{tabular}




\section{$6.3 \mathrm{VOCs}$}

Reporting of HAPs VOC emissions at the Laboratory is also done conservatively. That is, conservative emission factors are used to estimate emissions from larger operations and facilities such as the steam plants and air curtain destructors. Emissions from laboratories and similar smaller-scale operations are typically conservatively estimated by assuming the entire quantity of chemicals purchased during the year is emitted. LANL emitted approximately 19 tons of total VOCs in 2001 [LANL2003a] and 15 tons in 2002 [LANL2003b].

Of the 46 NonRadNET HAPs VOCs, 41 are specifically used at LANL [LANL2003a, LANL2003b]. Table 6-3 lists those LANL HAPs VOCs and their conservatively estimated emissions, in tons, for 2001 and 2002. The more significant emissions (by weight) are shaded in the table.

Table 6-3. NonRadNET HAPs VOC Chemicals Used at LANL

\begin{tabular}{|l|l|l|l|}
\hline \multicolumn{1}{|c|}{ CAS \# } & \multicolumn{1}{|c|}{ Name } & \multicolumn{1}{|c|}{$\begin{array}{c}\mathbf{2 0 0 1} \\
\text { (tons) }\end{array}$} & \multicolumn{1}{|c|}{$\begin{array}{c}\mathbf{2 0 0 2} \\
\text { (tons) }\end{array}$} \\
\hline $100-41-4$ & Ethyl Benzene & 0.02 & 0.018 \\
\hline $100-42-5$ & Styrene & 0.007 & 0.101 \\
\hline $100-44-7$ & Chlorotoluene (Benzyl Chloride) & 0 & 0 \\
\hline $106-42-3$ & p-Xylene* & 0 & 0.001 \\
\hline $106-46-7$ & $1,4-$ Dichlorobenzene & 0 & 0.0005 \\
\hline $106-93-4$ & Ethylene Dibromide (1,2-Dibromoethane) & 0 & 0.0005 \\
\hline $106-99-0$ & 1,3 -Butadiene & 0 & 0.0001 \\
\hline $107-06-2$ & 1,2 -Dichloroethane (Ethylene Dichloride) & 0.017 & 0.077 \\
\hline $107-13-1$ & Acrylonitrile & 0 & 0.0005 \\
\hline $108-10-1$ & 4-Methyl-2-pentanone (Methyl isobutyl ketone) & 0.003 & 0 \\
\hline $108-38-3$ & m-Xylene* & 0.001 & 0.0002 \\
\hline $108-88-3$ & Toluene & 0.34 & 0.281 \\
\hline $108-90-7$ & Chlorobenzene & 0.025 & 0.018 \\
\hline $110-54-3$ & Hexane & 0.398 & 1.03 \\
\hline $120-82-1$ & $1,2,4-$ Trichlorobenzene & 0 & 0.0002 \\
\hline $123-91-1$ & $1,4-$ Dioxane (1,4-Diethyloxide) & 0.087 & 0.092 \\
\hline $127-18-4$ & Tetrachloroethene (Perchloroethylene, Tetrachloroethylene) & 0 & 0.016 \\
\hline $1634-04-4$ & Methyl tert-Butyl Ether & 0.004 & 0 \\
\hline $540-84-1$ & $2,2,4-$ Trimethylpentane (Isooctane) & 0.234 & 0.188 \\
\hline $56-23-5$ & Carbon Tetrachloride & 0.012 & 0.008 \\
\hline $67-56-1$ & Methanol (Methyl alcohol) & 0.91 & 0.854 \\
\hline $67-66-3$ & Chloroform & 0.094 & 0.204 \\
\hline $71-43-2$ & Benzene & 0.012 & 0.234 \\
\hline $71-55-6$ & $1,1,1-$ Trichloroethane (Methyl Chloroform) & 0.031 & 0.003 \\
\hline $74-83-9$ & Bromomethane (Methyl Bromide) & 0 & 0.0008 \\
\hline $74-85-1$ & Ethylene & 0.009 & 0.009 \\
\hline $74-87-3$ & Freon 40 Chloromethane (Methyl Chloride) & 0.116 & 0.015 \\
\hline $75-01-4$ & Vinyl Chloride & 0 & 0.001 \\
\hline $75-05-8$ & Acetonitrile & 0.66 & 0.954 \\
\hline & & & \\
\hline
\end{tabular}


Table 6-3 (cont.)

\begin{tabular}{|l|l|l|l|}
\hline \multicolumn{1}{|c|}{ CAS } & \multicolumn{1}{|c|}{ Name } & $\begin{array}{c}\text { 2001 } \\
\text { (tons) }\end{array}$ & \multicolumn{1}{|c|}{$\begin{array}{c}\mathbf{2 0 0 2} \\
\text { (tons) }\end{array}$} \\
\hline $75-07-0$ & Acetaldehyde & 0 & 0.047 \\
\hline $75-09-2$ & Methylene Chloride (Dichloromethane) & 0.436 & 1.45 \\
\hline $75-25-2$ & Bromoform & 0 & 0 \\
\hline $75-34-3$ & 1,1-Dichloroethane (Ethylidene Dichloride) & 0 & 0.000001 \\
\hline $75-35-4$ & 1,1-Dichloroethene (Vinylidene Chloride) & 0 & 0.0000006 \\
\hline $78-87-5$ & 1,2-Dichloropropane (Propylene Dichloride) & 0 & 0.002 \\
\hline $78-93-3$ & 2-Butanone (Methyl Ethyl Ketone) & 0.297 & 0.166 \\
\hline $79-00-5$ & 1,1,2-Trichloroethane & 0.002 & 0.0006 \\
\hline $79-01-6$ & Trichloroethene (Trichloroethylene) & 0.51 & 0.025 \\
\hline $91-20-3$ & Naphthalene & 0 & 0.0006 \\
\hline $95-47-6$ & o-Xylene* & 0.004 & 0.006 \\
\hline $95-63-6$ & $1,2,4-$-Trimethylbenzene & 0.013 & 0.013 \\
\hline
\end{tabular}

*Besides specific m,p, and o xylene, LANL also reported emissions of "mixed" xylenes (CAS \# 1330-20-7) of 0.069 and 0.064 tons for 2001 and 2002, respectively.

For non-HAPs LANL emissions monitored by NonRadNET, the 2001/2002 EPCRA Reports [LANL2001, LANL2002b] and the 2001/2002 ACIS Database were used to estimate emissions.

Table 6-4 gives the quantities, in tons, of these NonRadNET VOCs purchased at LANL during 2001 and 2002. They could be used as a conservative estimate of the emissions of these materials. The more significant uses (by weight) are shaded in the table.

Table 6-4. Other NonRadNET VOC Chemicals Used at LANL

\begin{tabular}{|l|l|c|c|}
\hline \multicolumn{1}{|c|}{ CAS } & \multicolumn{1}{|c|}{ Name } & $\begin{array}{c}\mathbf{2 0 0 1} \\
\text { (tons) }\end{array}$ & $\begin{array}{c}\mathbf{2 0 0 2} \\
\text { (tons) }\end{array}$ \\
\hline $107-39-1$ & 2,4,4-Trimethyl-1-pentene & 0.32 & 0 \\
\hline $115-07-1$ & Propylene & 2.4 & 1.05 \\
\hline $60-29-7$ & Diethyl ether & 0.28 & 0.13 \\
\hline $64-17-5$ & Ethanol (Ethyl alcohol) & 1.2 & 2.05 \\
\hline $67-63-0$ & 2-Propanol (Isopropyl Alcohol) & 0.41 & 0.53 \\
\hline $67-64-1$ & Acetone (2-Propanone) & 1.26 & 1.37 \\
\hline $74-85-1$ & Ethylene & 0.05 & 0 \\
\hline $74-86-2$ & Acetylene & 0.65 & 0.89 \\
\hline $74-98-6$ & Propane & 36.3 & 19.8 \\
\hline $75-45-6$ & Freon 22 (Chlorodifluoromethane) & 2.54 & 1.25 \\
\hline $75-69-4$ & Freon 11 (Trichlorofluoromethane) & 0.06 & 0 \\
\hline $76-13-1$ & Freon 113 (1,1,2-Trichloro-1,2,2-trifluoroethane) & 0.03 & 0 \\
\hline $811-97-2$ & Halocarbon 134A & 0.14 & 0.04 \\
\hline $95-63-6$ & 1,2,4-Trimethylbenzene & 0.01 & 0 \\
\hline
\end{tabular}

It is important to observe that acetylene and propane are not normally emitted unburned. So listing their entire inventories as "emitted" is not reasonable. Instead, a very small fraction of these unburned material inventories would be emitted. 
Other sources of VOCs, besides LANL, include evaporative emissions from commercial fueling stations, non-Laboratory vehicles, normal building construction materials, natural sources, private and commercial chemical use, and other sources. To put the LANL VOC emissions into perspective, the annual VOC emissions from commuter traffic in Los Alamos County are roughly 400 tons per year, greatly overshadowing total LANL VOC emissions. Emissions of VOCs from fireplaces in Los Alamos County are approximately 41 tons per year. (See Appendix B for the details of these two estimates.)

Thus, except for "large" emissions of VOCs foreign to vehicle emissions and other combustion sources, LANL contributions to airborne VOC emissions are not likely to be discernable in ambient air. Such nonvehicle and noncombustion emissions at LANL could include those VOCS in Table 65. These LANL VOCs were detected in at least $50 \%$ of the NonRadNET measurements. The more significant chemicals (by weight) are shaded in the table. See Section 7 for a summary of these measurements.

Table 6-5. Frequently Detected* LANL VOC Chemical Usage Not Found in Vehicle Emissions

\begin{tabular}{|l|l|c|c|}
\hline \multicolumn{1}{|c|}{ CAS } & \multicolumn{1}{|c|}{ Name } & $\begin{array}{c}\mathbf{2 0 0 1 - 2 0 0 2} \\
\text { Usage (tons) }\end{array}$ & $\begin{array}{c}\text { \% Detection } \\
\text { Frequency }\end{array}$ \\
\hline $107-39-1$ & $2,4,4-$ Trimethyl-1-pentene & 0.32 & 61 \\
\hline $115-07-1$ & Propylene & 3.4 & 100 \\
\hline $56-23-5$ & Carbon Tetrachloride & 0.018 & 100 \\
\hline $67-66-3$ & Chloroform & 0.29 & 76 \\
\hline $71-55-6$ & 1,1,1-Trichloroethane (Methyl Chloroform) & 0.033 & 99 \\
\hline $74-85-1$ & Ethylene & 0.05 & 100 \\
\hline $74-83-9$ & Bromomethane (Methyl Bromide) & 8 E-4 & 62 \\
\hline $74-86-2$ & Acetylene & 1.54 & 100 \\
\hline $74-87-3$ & Freon 40 Chloromethane (Methyl Chloride) & 0.14 & 100 \\
\hline $75-09-2$ & Methylene Chloride (Dichloromethane) & 1.9 & 99 \\
\hline $75-45-6$ & Freon 22 (Chlorodifluoromethane) & 3.8 & 100 \\
\hline $75-69-4$ & Freon 11 (Trichlorofluoromethane) & 0.06 & 100 \\
\hline $76-13-1$ & Freon 113 (1,1,2-Trichloro-1,2,2-trifluoroethane) & 0.03 & 100 \\
\hline $811-97-2$ & Halocarbon 134A & 0.18 & 99 \\
\hline
\end{tabular}

$*>50 \%$ detects

Each of the VOCs in Table 6-5 above is discussed in the following paragraphs, with the intent of trying to determine if sufficient evidence exists to conclude that the NonRadNET results for the VOC are attributable to LANL.

To our knowledge the compound, 2,4,4-trimethyl-1-pentene, is not commonly used in New Mexico outside of the Laboratory. This compound is not classified as a HAP. Although during the two years of interest, LANL purchased and used much less than a ton of this material, we are not aware of any other local sources of this compound. Oddly, it was detected much more frequently in samples taken at the White Rock location than at the other two locations nearer the center of the 
Laboratory. However, the average concentration at the Diamond Drive location was higher than the other two locations. Section 8 of this paper compares NonRadNET results to national values, but we were unable to find a national value with which to compare this chemical.

Propylene, which is not a HAP, is a very common component of many plastics (e.g., polypropylene). The Laboratory used several tons of propylene during the two years of interest. The average concentration at the Diamond Drive location was two to three times the averages at the other two locations. A comparable national value in Section 8 is higher than the average at Diamond Drive.

Carbon tetrachloride is a HAP. It was historically used as a refrigerant, an aerosol propellant, solvent, grain fumigant, and extensively in dry cleaning. It is primarily used in industrial processes now. The Laboratory used very little, about 36 pounds, during 2001-2002. The average values at all three NonRadNET locations were similar and split the two national values (below one, above the other) given in Section 8 .

Chloroform is a HAP. It is used to make some refrigerants but also occurs naturally as a plant volatile. LANL used substantially less than a ton of chloroform during 2001-2002. The three NonRadNET locations measured essentially the same average concentration. That value was significantly less than the national values in Section 8 .

1,1,1-Trichloroethane is a HAP. It is used as a solvent/degreaser and is used in home cleaners, glues, aerosols, and similar consumer products. It is a substitute for carbon tetrachloride. The Laboratory used about 66 pounds of the material in 2001-2002. The highest average for the three NonRadNET stations was the same as one national value and about 20 times less than a second national value in Section 8.

Ethylene is not a HAP, occurs naturally in plants, and is used as a ripener. LANL used about 100 pounds in 2001-2002. The highest NonRadNET average was at the Diamond Drive location and was just less than half of the national value in Section 8. The other two stations were substantially lower.

Bromomethane is a HAP, occurs naturally in marine organisms, and is used as a fumigant. LANL used less than 10 pounds in 2001-2002. The highest NonRadNET average was at the White Rock location and was less than the national value in Section 8. The other two stations were substantially lower.

Acetylene is not a HAP. It is primarily used as welding gas. Although LANL used more than a ton of it during 2001-2002, it was mostly burned with only a small fraction escaping unburned. The average concentrations at Diamond Drive and at the medical center were about five times the White Rock average. The average value measured was less than half of the national value in Section 8.

Chloromethane (Freon 40), although classed as a HAP, is about 99\% natural. Therefore, the small LANL emissions of this compound are not likely to be detectable above the natural levels. The comparable national value for Freon 40 in Section 8 is higher than the averages measured by NonRadNET. 
Methylene chloride, a HAP, occurs naturally. It is the active ingredient in many paint strippers. It is also used as an aerosol propellant for paint, a fumigant, and a degreener for fruit. LANL used almost 4000 pounds in 2001-2002. However, the largest NonRadNET average was significantly less than the national values in Section 8.

Freon 22 is a non-HAP refrigerant. LANL used about 7600 pounds of it during 2001-2002. It is present in consumer and commercial refrigeration systems. The average value at the medical center was about 3.5 times the average at the other two stations. We do not know if the medical center uses Freon 22 in large quantities, and we do not have any national values with which to compare.

Freon 11, Freon 113, and Halocarbon 134A are all non-HAP refrigerants. LANL used very little of these materials in 2001-2002. The averages are relatively consistent between NonRadNET sites. We do not have any national values with which to compare them. 


\subsection{Summary of Ambient Air Measurements}

This section summarizes the quantitative results of NonRadNET. It includes summary tables of averages and ranges for the entire program. Tables 7-1 through 7-5 summarize the NonRadNET ambient air concentrations for particulate matter, inorganic elements, and VOCs.

\subsection{Particulate Matter}

Summary results for the three measured particle types: TSP, $\mathrm{PM}_{10}$, and $\mathrm{PM}_{2.5}$ are given in Table 7-1.

Table 7-1. Average Concentrations of NonRadNET Particulate Matter

\begin{tabular}{|c|c|c|c|c|}
\hline Particle & Measurements* & $\begin{array}{c}\text { Range } \\
\left(\mathbf{\mu g} / \mathbf{m}^{\mathbf{3}}\right)\end{array}$ & $\begin{array}{c}\text { Mean Conc. } \\
\left(\boldsymbol{\mu g} / \mathbf{m}^{\mathbf{3}}\right)\end{array}$ & Std Dev \\
\hline $\mathrm{TSP}$ & $77 / 120$ & $9.7-299.6$ & 52.1 & 43.6 \\
\hline $\mathrm{PM}_{10}$ & $29,711 / 31,158$ & $0-983.6$ & 18.8 & 21.6 \\
\hline $\mathrm{PM}_{2.5}$ & $62,612 / 66,650$ & $0-92.8$ & 7.9 & 4.9 \\
\hline
\end{tabular}

The TSP measurements were made for 24 hours once every 12 days as described in subsections 3.3 and 4.1 above. Therefore, the TSP range is expressed as 24-hour averages. The TSP mean concentration is the program-wide (three stations) and program-term (5 quarters) average of those data. The TSP results for the first quarter of data (fourth quarter of 2001) were all rejected as probably invalid. See the 2001 Environmental Surveillance Report for discussion on this issue [LANL2002].

The $\mathrm{PM}_{10}$ and $\mathrm{PM}_{2.5}$ measurements were made continuously. The ranges in Table 7-1 are for 30minute averages. The mean concentrations for $\mathrm{PM}_{10}$ and $\mathrm{PM}_{2.5}$ are the program-wide (three stations) and program-term (5 quarters) averages of those data.

\subsection{Inorganic Elements}

Summary results for the 20 inorganic elemental data are given in Table 7-2. Note that these results are given in nanograms per cubic meter $\left(\mathrm{ng} / \mathrm{m}^{3}\right)$ and not in $\mu \mathrm{g} / \mathrm{m}^{3}$. Other concentration units in this paper are normally in $\mu \mathrm{g} / \mathrm{m}^{3}$. HAPs are shown in bold, and average concentrations equal to or exceeding $20 \mathrm{ng} / \mathrm{m}^{3}$ are shaded.

In decreasing concentration order, iron, copper, manganese, and barium had the highest average concentrations. The average iron concentration was 16 times higher than the next highest average, copper.

A common interpretive technique for inorganic elements is to calculate elemental ratios to the element measured that has the minimum uncertainty and is not likely to have any source besides resuspended local soil materials. Commonly selected elements used for this comparison purpose include silicon $(\mathrm{Si})$, aluminum $(\mathrm{Al})$, iron $(\mathrm{Fe})$, manganese $(\mathrm{Mn})$, and rare earth elements such as cerium $(\mathrm{Ce})$. These elemental ratios are then compared to corresponding ones taken from chemical analysis of local soils or to average terrestrial crustal abundance data. See the 2001 and 2002 
Environmental Surveillance Reports [LANL2002, LANL2003] for an analysis of elemental ratios. The 2002 Environmental Surveillance Report [LANL2003] concludes that there is some evidence for enhancement to the soil background levels for copper, iron, manganese, antimony, and zinc. Possible explanations for these enhancements are given in the 2002 Report.

Table 7-2. Average Concentrations of NonRadNET Inorganic Elements

\begin{tabular}{|c|c|c|c|c|c|}
\hline Element & Symbol & Measurements* & $\begin{array}{c}\text { Range } \\
\left(\mathbf{n g} / \mathbf{m}^{\mathbf{3}}\right)\end{array}$ & $\begin{array}{c}\text { Mean Conc. } \\
\left(\mathbf{n g} / \mathbf{m}^{\mathbf{3}}\right)\end{array}$ & Std Dev \\
\hline Antimony & $\mathbf{S b}$ & $\mathbf{1 5 8}$ & $\mathbf{0 . 1}-\mathbf{1 . 4}$ & $\mathbf{0 . 4 6}$ & $\mathbf{0 . 2 5}$ \\
\hline Arsenic & $\mathbf{A s}$ & $\mathbf{1 0 7}$ & $\mathbf{- 0 . 0 1 - 2 . 1 5}$ & $\mathbf{0 . 4 2}$ & $\mathbf{0 . 3 0}$ \\
\hline Barium & $\mathrm{Ba}$ & 238 & $2.9-110$ & 21 & 15 \\
\hline Beryllium & $\mathbf{B e}$ & $\mathbf{1 1 7}$ & $\mathbf{0 . 0 0 0 8}-\mathbf{0 . 5 1}$ & $\mathbf{0 . 0 6}$ & $\mathbf{0 . 0 6}$ \\
\hline Cadmium & $\mathbf{C d}$ & $\mathbf{1 5 3}$ & $\mathbf{0 . 0 0 4 - 0 . 3 8}$ & $\mathbf{0 . 0 8}$ & $\mathbf{0 . 0 5}$ \\
\hline Cerium & $\mathrm{Ce}$ & 108 & $0.20-6.2$ & 2.0 & 1.3 \\
\hline Chromium & $\mathbf{C r}$ & $\mathbf{1 6 1}$ & $\mathbf{0 . 1 0}-\mathbf{1 0}$ & $\mathbf{1 . 9}$ & $\mathbf{1 . 6}$ \\
\hline Cobalt & $\mathbf{C o}$ & $\mathbf{1 6 2}$ & $\mathbf{0 . 0 2}-\mathbf{1 . 8}$ & $\mathbf{0 . 3 3}$ & $\mathbf{0 . 2 8}$ \\
\hline Copper & $\mathrm{Cu}$ & 152 & $11-235$ & 47 & 28 \\
\hline Iron & $\mathrm{Fe}$ & 63 & $68-2190$ & 760 & 520 \\
\hline Lead & $\mathbf{P b}$ & $\mathbf{1 5 4}$ & $\mathbf{0 . 6 1}-\mathbf{1 6}$ & $\mathbf{2 . 7}$ & $\mathbf{2 . 2}$ \\
\hline Manganese & $\mathbf{M n}$ & $\mathbf{1 4 2}$ & $\mathbf{2 . 1}-\mathbf{1 2 2}$ & $\mathbf{2 1}$ & $\mathbf{1 8}$ \\
\hline Neodymium & $\mathrm{Nd}$ & 105 & $0.08-2.3$ & 0.76 & 0.51 \\
\hline Nickel & $\mathbf{N i}$ & $\mathbf{1 5 5}$ & $\mathbf{0 . 1 4}-\mathbf{4 . 2}$ & $\mathbf{1 . 1}$ & $\mathbf{0 . 8}$ \\
\hline Selenium & $\mathbf{S e}$ & $\mathbf{9 0}$ & $\mathbf{0 . 1 0}-\mathbf{0 . 8 4}$ & $\mathbf{0 . 3 6}$ & $\mathbf{0 . 1 8}$ \\
\hline Silver & $\mathrm{Ag}$ & 160 & $0.009-1.14$ & 0.10 & 0.12 \\
\hline Strontium & $\mathrm{Sr}$ & 144 & $0.93-41$ & 8.1 & 6.5 \\
\hline Thallium & $\mathrm{Tl}$ & 113 & $0.004-0.11$ & 0.02 & 0.02 \\
\hline Vanadium & $\mathrm{V}$ & 112 & $0.30-12$ & 2.0 & 1.6 \\
\hline Zinc & $\mathrm{Zn}$ & 219 & $5.2-53$ & 19 & 10 \\
\hline *Number of measurements from all analytical methods. & & & \\
HAPs are shown in bold. \\
Concentrations over $20 \mathrm{ng} / \mathrm{m}^{3}$ are shaded. & & & & \\
\hline
\end{tabular}

\subsection{Volatile Organic Compounds}

This subsection summarizes the measurements of the 160 VOCs for 129 combined samples at the three sampling locations. Because so many VOCs were included in our analyses, we have divided the summary results into several groups, based on detection frequency, in an attempt to avoid overwhelming readers with so much data at once.

Table 7-3 provides a summary of those VOCs that were detected above the detection limit in at least $50 \%$ of all samples. Referring back to Section 5, note that $72 \%$ (62 out of 86 ) of these frequently detected VOCs are components of vehicle fuels or their exhausts. Thirty-eight percent (33) of these 86 VOCs are used at LANL, and 14 of those 33 VOCs used at LANL are not fuel related. (See Section 6.) Twenty-one of the 86 VOCs in Table 7-3 also occur naturally. Of those, benzaldehyde, butyraldehyde, and alpha-pinene are primarily natural and are not used at LANL in any significant quantity. Entries shown in bold are on the EPA list of 188 HAPs. 
Ethyl alcohol (ethanol, "grain alcohol"), not a HAP, had the highest average concentration (23 $\mu \mathrm{g} / \mathrm{m}^{3}$ ) of any of the 160 measured VOCs. As discussed in Section 5, it has multiple natural and human-made sources and uses: biological decay, fires, volcanoes, vehicle fuels, consumer and industrial solvent use, and other commercial uses. Section 6 shows that LANL used one to two tons of ethyl alcohol each year during 2001-2002, a relatively small quantity.

Other VOC materials used at LANL in near-ton or larger quantities during 2001-2002 included methyl alcohol, acetone, hexane, toluene, propylene, propane, acetonitrile, and Freon 22. Of these LANL larger-use VOCs, only methyl alcohol, acetone, toluene, and propane were detected in greater than $2 \mu \mathrm{g} / \mathrm{m}^{3}$ quantities. Although not used in significant quantities at LANL, acetaldehyde (primarily natural), butane (refinery/fuel gas), ethane (refinery gas), isobutane (common aerosol propellant), 2-methylbutane, pentane (refinery gas), and Freon 12 (refrigerant) were detected at average levels over $2 \mu \mathrm{g} / \mathrm{m}^{3}$. All 12 VOCs in Table $7-3$ averaging over $2 \mu \mathrm{g} / \mathrm{m}^{3}$ are shaded.

All other detected VOCs averaged less than $2 \mu \mathrm{g} / \mathrm{m}^{3}$. If further analysis of the origins, hazard categories, or emission sources of these frequently detected VOCs is of interest, see Sections 5 and 6. Sections 8 and 9 compare these average results with national values and with exposure limits.

Table 7-4 provides a summary of those VOCS that were detected between $10 \%$ and $50 \%$ of the time in samples. Again, using Section 5 for reference, a significant fraction, 30\% (8 of 27), of these less frequently detected VOCs are fuel related. Five (19\%) of these 27 less frequently detected VOCs are used at LANL, four of which are not fuel related. (See Section 6.)

Six of the 27 VOCs in Table 7-4 also occur naturally. Limonene and beta-pinene are almost exclusively natural and are not used in any significant quantity at LANL.

Table 7-5 provides a summary of those VOCS that were detected less than $10 \%$ of the time in samples. As in the previous discussions, a significant fraction, 27\% (13 out of 48), of these infrequently detected VOCs, is fuel related. Eleven (23\%) of these 48 infrequently detected VOCs are used at LANL, six of which are not fuel related. (See Section 6.) Two of the 48 VOCs in Table 7-5 also occur naturally.

Note that in Tables 7-3 through 7-5 only the "detects" were used in the average and standard deviation calculations. Thus, those calculations for the less frequently detected VOCS are biased, very likely on the high side. Furthermore, some ranges that contain "less-than" results begin with a value other than a "less-than" result. This condition results when the lowest detected result was actually lower than the "less-than" for other samples in the set. 
Table 7-3. Average Concentrations of VOCs Detected in $>\mathbf{5 0} \%$ of NonRadNET Samples

\begin{tabular}{|c|c|c|c|c|c|c|}
\hline CAS \# & Name & LANL & Detect \% & Range $\left(\mu \mathrm{g} / \mathrm{m}^{3}\right)$ & $\begin{array}{c}\text { Mean Conc. } \\
\left(\mu \mathrm{g} / \mathrm{m}^{3}\right)\end{array}$ & Std Dev \\
\hline $100-42-5$ & Styrene & $\mathbf{X}$ & $63.6 \%$ & $0.016-0.23$ & $\mathbf{0 . 0 7}$ & 0.04 \\
\hline $103-65-1$ & n-Propylbenzene & & $56.6 \%$ & $0.042-0.26$ & 0.09 & 0.04 \\
\hline 106-42-3 & p-Xylene (including 108-38-3 m-Xylene) & $\mathbf{X}$ & $100.0 \%$ & $0.083-4.3$ & 1.1 & 0.8 \\
\hline $106-97-8$ & Butane & & $100.0 \%$ & $0.20-312$ & 12 & 37 \\
\hline $107-39-1$ & 2,4,4-Trimethyl-1-pentene & $\mathrm{X}$ & $61.2 \%$ & $0.015-0.19$ & 0.07 & 0.03 \\
\hline $107-83-5$ & Isohexane (2-Methylpentane) & & $99.2 \%$ & $<0.08-24$ & 1.3 & 2.6 \\
\hline $108-08-7$ & 2,4-Dimethylpentane & & $94.6 \%$ & $0.02-2.6$ & 0.2 & 0.27 \\
\hline $108-67-8$ & 1,3,5-Trimethylbenzene & & $82.2 \%$ & $0.022-0.40$ & 0.11 & 0.06 \\
\hline $108-87-2$ & Methylcyclohexane & & $89.9 \%$ & $0.021-1.56$ & 0.16 & 0.21 \\
\hline $110-82-7$ & Cyclohexane & & $96.1 \%$ & $0.032-3.5$ & 0.26 & 0.4 \\
\hline $111-65-9$ & n-Octane & & $93.8 \%$ & $0.05-0.56$ & 0.15 & 0.09 \\
\hline $111-84-2$ & n-Nonane & & $93.8 \%$ & $0.023-2.4$ & 0.12 & 0.22 \\
\hline $1120-21-4$ & n-Undecane & & $68.2 \%$ & $0.016-0.27$ & 0.07 & 0.04 \\
\hline $115-07-1$ & Propylene & $\mathrm{X}$ & $100.0 \%$ & $0.05-1.7$ & 0.48 & 0.32 \\
\hline $123-72-8$ & Butyraldehyde & & $89.1 \%$ & $<0.08-12.6$ & 1.2 & 1.6 \\
\hline $124-18-5$ & n-Decane & & $89.1 \%$ & $0.015-0.19$ & 0.07 & 0.03 \\
\hline $142-82-5$ & Heptane & & $94.6 \%$ & $0.028-2.4$ & 0.25 & 0.28 \\
\hline $287-92-3$ & Cyclopentane & & $84.5 \%$ & $0.023-4.2$ & 0.22 & 0.49 \\
\hline 31394-54-4 & Isoheptane (2-Methylhexane) & & $96.9 \%$ & $0.028-7.2$ & 0.5 & 0.82 \\
\hline $4050-45-7$ & trans-2-Hexene & & $57.4 \%$ & $0.01-0.97$ & 0.09 & 0.15 \\
\hline
\end{tabular}


Table 7-3 (cont.)

\begin{tabular}{|c|c|c|c|c|c|c|}
\hline CAS \# & Name & LANL & Detect \% & Range $\left(\mu \mathrm{g} / \mathbf{m}^{3}\right)$ & $\begin{array}{c}\text { Mean Conc. } \\
\left(\mu \mathrm{g} / \mathrm{m}^{3}\right)\end{array}$ & Std Dev \\
\hline $463-82-1$ & Neopentane & & $54.3 \%$ & $0.005-1.4$ & 0.1 & 0.21 \\
\hline $513-35-9$ & 2-Methyl-2-butene & & $92.2 \%$ & $<0.015-14.3$ & 0.58 & 1.77 \\
\hline $526-73-8$ & 1,2,3-Trimethylbenzene & & $62.8 \%$ & $0.018-0.32$ & 0.08 & 0.05 \\
\hline 540-84-1 & 2,2,4-Trimethylpentane (Isooctane) & $\mathbf{X}$ & $99.2 \%$ & $0.032-4.3$ & 0.42 & $\mathbf{0 . 5 7}$ \\
\hline 56-23-5 & Carbon Tetrachloride & $\mathbf{X}$ & $100.0 \%$ & $0.17-1.0$ & 0.73 & 0.1 \\
\hline $564-02-3$ & 2,2,3-Trimethylpentane & & $69.8 \%$ & $0.01-0.31$ & 0.05 & 0.04 \\
\hline $565-59-3$ & 2,3-Dimethylpentane & & $93.0 \%$ & $0.032-3.8$ & 0.35 & 0.44 \\
\hline $565-75-3$ & 2,3,4-Trimethylpentane & & $72.9 \%$ & $<0.02-1.0$ & 0.34 & 0.14 \\
\hline $589-34-4$ & 3-Methylhexane & & $95.3 \%$ & $<0.08-4.2$ & 0.49 & 0.49 \\
\hline $589-81-1$ & 3-Methylheptane & & $58.9 \%$ & $0.02-0.41$ & 0.09 & 0.07 \\
\hline $590-18-1$ & cis-2-Butene & & $76.0 \%$ & $<0.01-6.7$ & 0.26 & 0.74 \\
\hline $592-13-2$ & 2,5-Dimethylhexane & & $66.7 \%$ & $0.01-0.34$ & 0.06 & 0.04 \\
\hline $592-27-8$ & 2-Methylheptane & & $78.3 \%$ & $0.06-2.0$ & 0.2 & 0.21 \\
\hline $592-41-6$ & 1-Hexene & & $65.9 \%$ & $0.027-0.81$ & 0.1 & 0.11 \\
\hline $592-76-7$ & 1-Heptene & & $74.4 \%$ & $0.02-1.7$ & 0.2 & 0.22 \\
\hline $611-14-3$ & 2-Ethyltoluene (o-Ethyltoluene) & & $71.3 \%$ & $0.023-0.34$ & 0.09 & 0.05 \\
\hline $620-14-4$ & 3-Ethyltoluene (m-Ethyltoluene) & & $96.1 \%$ & $0.04-0.95$ & 0.23 & 0.14 \\
\hline $622-96-8$ & 4-Ethyltoluene ( $\mathrm{p}$-Ethyltoluene) & & $78.3 \%$ & $0.03-0.42$ & 0.12 & 0.06 \\
\hline $624-64-6$ & trans-2-Butene & & $79.8 \%$ & $0.02-6.7$ & 0.26 & 0.71 \\
\hline $625-27-4$ & 2-Methyl-2-pentene & & $68.2 \%$ & $0.01-1.18$ & 0.1 & 0.17 \\
\hline $627-20-3$ & cis-2-Pentene & & $74.4 \%$ & $0.016-5.53$ & 0.29 & 0.78 \\
\hline $64-17-5$ & Ethanol (Ethyl alcohol) & $\mathrm{X}$ & $100.0 \%$ & $1.96-89.8$ & 23 & 16 \\
\hline $646-04-8$ & trans-2-Pentene & & $92.2 \%$ & $0.02-10.9$ & 0.5 & 1.4 \\
\hline $66-25-1$ & Hexanal & & $75.2 \%$ & $0.15-12.1$ & 1 & 1.4 \\
\hline $67-56-1$ & Methanol (Methyl alcohol) & $\mathbf{X}$ & $100.0 \%$ & $0.83-69.6$ & 10.8 & 7.6 \\
\hline $67-63-0$ & 2-Propanol (Isopropyl Alcohol) & $\mathrm{X}$ & $74.4 \%$ & $<0.03-2.3$ & 0.42 & 0.3 \\
\hline $67-64-1$ & Acetone (2-Propanone) & $\mathrm{X}$ & $100.0 \%$ & $1.65-64.6$ & 12 & 10 \\
\hline $67-66-3$ & Chloroform & $\mathbf{X}$ & $76.0 \%$ & $0.024-0.49$ & 0.04 & 0.04 \\
\hline $71-43-2$ & Benzene & $\mathbf{X}$ & $100.0 \%$ & $0.13-10.3$ & 1.3 & 1.2 \\
\hline
\end{tabular}

HAPs are shown in bold

Concentrations over $2 \mu \mathrm{g} / \mathrm{m}^{3}$ are shaded. 
Table 7-3 (cont.)

\begin{tabular}{|c|c|c|c|c|c|c|}
\hline CAS \# & Name & LANL & Detect \% & Range $\left(\mu \mathrm{g} / \mathrm{m}^{3}\right)$ & $\begin{array}{c}\text { Mean Conc. } \\
\left(\mu \mathrm{g} / \mathrm{m}^{3}\right)\end{array}$ & Std Dev \\
\hline 71-55-6 & 1,1,1-Trichloroethane (Methyl Chloroform) & $\mathbf{X}$ & $99.2 \%$ & $<0.07-0.80$ & 0.21 & 0.08 \\
\hline 74-83-9 & Bromomethane (Methyl Bromide) & $\mathbf{X}$ & $62.0 \%$ & $0.017-0.24$ & 0.04 & $\mathbf{0 . 0 3}$ \\
\hline $74-84-0$ & Ethane & & $100.0 \%$ & $1.4-26.2$ & 5.4 & 4.2 \\
\hline $74-85-1$ & Ethylene & $\mathrm{X}$ & $100.0 \%$ & $0.24-4.2$ & 1.3 & 0.7 \\
\hline $74-86-2$ & Acetylene & $\mathrm{X}$ & $100.0 \%$ & $0.20-4.9$ & 1.1 & 0.7 \\
\hline 74-87-3 & Freon 40 Chloromethane (Methyl Chloride) & $\mathbf{X}$ & $\mathbf{1 0 0 . 0 \%}$ & $0.31-1.7$ & 1.1 & 0.3 \\
\hline $74-98-6$ & Propane & $\mathrm{X}$ & $100.0 \%$ & $0.51-27.3$ & 3.4 & 3.8 \\
\hline 75-05-8 & Acetonitrile & $\mathbf{X}$ & $60.5 \%$ & $<0.05-1.1$ & 0.37 & 0.2 \\
\hline 75-07-0 & Acetaldehyde & $\mathbf{X}$ & $100.0 \%$ & $0.26-40.4$ & 8.1 & 6.1 \\
\hline 75-09-2 & Methylene Chloride (Dichloromethane) & $\mathbf{X}$ & $99.2 \%$ & $<0.06-2.3$ & 0.25 & 0.27 \\
\hline $75-28-5$ & Isobutane & & $100.0 \%$ & $0.082-107$ & 3.7 & 12 \\
\hline $75-45-6$ & Freon 22 (Chlorodifluoromethane) & $\mathrm{X}$ & $100.0 \%$ & $0.41-34.7$ & 1.4 & 3.5 \\
\hline $75-69-4$ & Freon 11 (Trichlorofluoromethane) & $\mathrm{X}$ & $100.0 \%$ & $0.44-1.98$ & 1.65 & 0.17 \\
\hline $75-71-8$ & Freon 12 (Dichlorodifluoromethane) & & $100.0 \%$ & $0.79-3.8$ & 2.96 & 0.33 \\
\hline $75-83-2$ & 2,2-Dimethylbutane (Neohexane) & & $83.7 \%$ & $0.023-4.2$ & 0.22 & 0.48 \\
\hline $76-13-1$ & Freon 113 (1,1,2-Trichloro-1,2,2-trifluoroethane) & $\mathrm{X}$ & $100.0 \%$ & $0.11-1.13$ & 0.66 & 0.14 \\
\hline $76-14-2$ & Freon 114 (1,2-Dichlorotetrafluoroethane) & & $99.2 \%$ & $<0.04-0.18$ & 0.1 & 0.02 \\
\hline $763-29-1$ & 2-Methyl-1-pentene & & $54.3 \%$ & $0.0084-0.82$ & 0.08 & 0.13 \\
\hline $78-78-4$ & 2-Methylbutane (Isopentane) & & $100.0 \%$ & $0.22-210$ & 9 & 24 \\
\hline $78-79-5$ & Isoprene & & $83.7 \%$ & $0.011-1.0$ & 0.2 & 0.23 \\
\hline 78-93-3 & 2-Butanone (Methyl Ethyl Ketone) & $\mathbf{X}$ & $90.7 \%$ & $<0.11-8.2$ & 1.1 & 1.2 \\
\hline $79-29-8$ & 2,3-Dimethylbutane & & $98.4 \%$ & $0.02-6.8$ & 0.33 & 0.74 \\
\hline $80-56-8$ & alpha-Pinene & & $89.9 \%$ & $0.027-9.7$ & 1 & 1.7 \\
\hline $811-97-2$ & Halocarbon 134A & $X$ & $99.2 \%$ & $<0.02-1.08$ & 0.24 & 0.16 \\
\hline $95-47-6$ & o-Xylene & $\mathbf{X}$ & $99.2 \%$ & $0.064-1.7$ & $\mathbf{0 . 4 3}$ & 0.29 \\
\hline $95-63-6$ & 1,2,4-Trimethylbenzene & $\mathrm{X}$ & $99.2 \%$ & $0.041-1.37$ & 0.31 & 0.21 \\
\hline 96-14-0 & 3-Methylpentane & & $99.2 \%$ & $<0.04-14$ & 0.7 & 1.5 \\
\hline $96-37-7$ & Methylcyclopentane & & $99.2 \%$ & $<0.02-8.2$ & 0.4 & 0.9 \\
\hline
\end{tabular}

HAPs are shown in bold.

Concentrations over $2 \mu \mathrm{g} / \mathrm{m}^{3}$ are shaded. 
Table 7-4. Average Concentrations of VOCs Detected in $10 \%$ to $50 \%$ of NonRadNET Samples

\begin{tabular}{|c|c|c|c|c|c|c|}
\hline CAS & Name & LANL & Detect \% & Range $\left(\mu \mathrm{g} / \mathrm{m}^{3}\right)$ & $\begin{array}{c}\text { Mean Conc. } \\
\left(\mu \mathrm{g} / \mathrm{m}^{3}\right)\end{array}$ & Std Dev \\
\hline 108-05-4 & Vinyl Acetate & & $31.0 \%$ & $0.63-4.5$ & 1.7 & 0.9 \\
\hline 108-90-7 & Chlorobenzene & $\mathbf{X}$ & $26.4 \%$ & $0.022-0.088$ & 0.04 & 0.01 \\
\hline $111-66-0$ & 1-Octene & & $31.0 \%$ & $0.021-0.27$ & 0.08 & 0.06 \\
\hline 120-82-1 & 1,2,4-Trichlorobenzene & $\mathbf{X}$ & $17.1 \%$ & $0.023-1.18$ & 0.22 & 0.32 \\
\hline $124-11-8$ & 1-Nonene & & $14.0 \%$ & $0.041-0.18$ & 0.08 & 0.03 \\
\hline 127-18-4 & $\begin{array}{l}\text { Tetrachloroethene (Perchloroethylene, } \\
\text { Tetrachloroethylene) }\end{array}$ & $\mathbf{X}$ & $28.7 \%$ & $0.018-0.56$ & 0.13 & 0.1 \\
\hline $127-91-3$ & beta-Pinene & & $47.3 \%$ & $0.017-0.60$ & 0.15 & 0.12 \\
\hline $138-86-3$ & Limonene & & $33.3 \%$ & $0.027-0.61$ & 0.12 & 0.1 \\
\hline $142-29-0$ & Cyclopentene & & $43.4 \%$ & $0.010-1.07$ & 0.09 & 0.17 \\
\hline $3522-94-9$ & 2,2,5-Trimethylhexane & & $45.0 \%$ & $0.016-0.15$ & 0.04 & 0.02 \\
\hline 496-11-7 & Indan & & $34.1 \%$ & $0.018-0.13$ & 0.04 & 0.02 \\
\hline $563-45-1$ & 3-Methyl-1-butene & & $34.1 \%$ & $<0.02-2.6$ & 0.27 & 0.53 \\
\hline $691-38-3$ & cis/trans-4-Methyl-2-pentene & & $31.8 \%$ & $0.01-0.81$ & 0.11 & 0.16 \\
\hline $693-89-0$ & 1-Methylcyclopentene & & $31.8 \%$ & $0.024-0.84$ & 0.11 & 0.15 \\
\hline $71-36-3$ & 1-Butanol (n-Butyl Alcohol) & & $14.0 \%$ & $0.08-4.6$ & 0.8 & 1 \\
\hline 75-00-3 & Chloroethane (Ethyl Chloride) Freon 160 & & $27.9 \%$ & $<0.02-0.28$ & 0.12 & 0.05 \\
\hline $75-43-4$ & Freon 21 (Dichlorofluoromethane) & & $10.1 \%$ & $0.020-0.055$ & 0.03 & 0.01 \\
\hline $7642-09-3$ & cis-3-Hexene & & $38.0 \%$ & $0.010-0.76$ & 0.09 & 0.12 \\
\hline $7688-21-3$ & cis-2-Hexene & & $28.7 \%$ & $0.014-0.49$ & 0.07 & 0.1 \\
\hline $821-95-4$ & 1-Undecene & & $14.7 \%$ & $<0.05-0.95$ & 0.27 & 0.21 \\
\hline 87-68-3 & Hexachlorobutadiene & & $10.9 \%$ & $<0.026-1.6$ & $\mathbf{0 . 3 5}$ & 0.42 \\
\hline 91-20-3 & Naphthalene & $\mathbf{X}$ & $14.0 \%$ & 0.081-0.17 & 0.11 & $\mathbf{0 . 0 2}$ \\
\hline $922-62-3$ & cis-3-Methyl-2-pentene & & $27.9 \%$ & $0.01-0.63$ & 0.1 & 0.12 \\
\hline $99-87-6$ & 4-Isopropyltoluene (p-Cymeme) & & $28.7 \%$ & $0.031-0.18$ & 0.08 & 0.02 \\
\hline
\end{tabular}


Table 7-5. Average Concentrations of VOCs Detected in $<\mathbf{1 0 \%}$ of NonRadNET Samples

\begin{tabular}{|c|c|c|c|c|c|c|}
\hline CAS & Name & LANL & \% Detected & Range $\left(\mu \mathrm{g} / \mathrm{m}^{3}\right)$ & $\begin{array}{c}\text { Mean Conc. } \\
\left(\mu \mathrm{g} / \mathbf{m}^{3}\right) \\
\end{array}$ & Std Dev \\
\hline $10061-01-5$ & cis-1,3-Dichloropropene & & $0.0 \%$ & $<0.036-<0.19$ & & \\
\hline $104-51-8$ & n-Butylbenzene & & $7.8 \%$ & $0.02-0.17$ & 0.05 & 0.04 \\
\hline $105-05-5$ & 1,4-Diethylbenzene (p-Diethylbenzene) & & $4.7 \%$ & $0.01-0.089$ & 0.04 & 0.03 \\
\hline $106-43-4$ & 4-Chlorotoluene & & $0.0 \%$ & $<0.24-<1.8$ & & \\
\hline 107-13-1 & Acrylonitrile & $\mathbf{X}$ & $0.0 \%$ & $<0.05-<0.14$ & & \\
\hline $107-40-4$ & 2,4,4-Trimethyl-2-pentene & & $0.8 \%$ & $<0.04-<0.33$ & & \\
\hline $108-41-8$ & $\begin{array}{l}\text { 3-Chlorotoluene (measured as 2- and 3- } \\
\text { Chlorotoluene) }\end{array}$ & & $0.0 \%$ & $<0.34-<3.2$ & & \\
\hline $110-83-8$ & Cyclohexene & & $3.1 \%$ & $0.023-0.08$ & 0.04 & 0.02 \\
\hline $141-93-5$ & 1,3-Diethylbenzene (m-Diethylbenzene) & & $7.0 \%$ & $0.012-0.077$ & 0.03 & 0.02 \\
\hline $14686-13-6$ & trans-2-Heptene & & $4.7 \%$ & $0.026-0.14$ & 0.07 & 0.05 \\
\hline 14686-14-7 & trans-3-Heptene & & $7.0 \%$ & $0.036-0.43$ & 0.15 & 0.14 \\
\hline $156-59-2$ & cis-1,2 Dichloroethene & & $0.0 \%$ & $<0.066-<0.17$ & & \\
\hline $156-60-5$ & trans-1,2-Dichloroethene & & $0.0 \%$ & $<0.038-<0.15$ & & \\
\hline 1634-04-4 & Methyl tert-Butyl Ether & & $7.8 \%$ & $0.012-0.16$ & 0.05 & 0.04 \\
\hline $2198-23-4$ & 4-Nonene & & $0.0 \%$ & $<0.11-<0.32$ & & \\
\hline $538-93-2$ & Isobutylbenzene & & $0.8 \%$ & $<0.27-<1.9$ & & \\
\hline $541-73-1$ & 1,3-Dichlorobenzene & & $6.2 \%$ & $0.022-0.30$ & 0.14 & 0.1 \\
\hline $591-49-1$ & 1-Methylcyclohexene & & $0.0 \%$ & $<0.07-<0.28$ & & \\
\hline 593-60-2 & Vinyl bromide & & $0.0 \%$ & $<0.037-<0.41$ & & \\
\hline
\end{tabular}


Table 7-5 (cont.)

\begin{tabular}{|c|c|c|c|c|c|c|}
\hline CAS & Name & LANL & $\%$ Detected & Range $\left(\mu \mathrm{g} / \mathbf{m}^{3}\right)$ & $\begin{array}{l}\text { Mean Conc. } \\
\left(\mu \mathrm{g} / \mathrm{m}^{3}\right)\end{array}$ & Std Dev \\
\hline $60-29-7$ & Diethyl ether & $\mathrm{X}$ & $0.0 \%$ & $<0.05-<0.38$ & & \\
\hline $691-37-2$ & 4-Methyl-1-pentene & & $6.2 \%$ & $<0.017-0.52$ & 0.17 & 0.18 \\
\hline $71-23-8$ & 1-Propanol & & $5.4 \%$ & $<0.18-2.7$ & 1.5 & 0.8 \\
\hline $74-97-5$ & Bromochloromethane & & $0.0 \%$ & $<0.02-<0.11$ & & \\
\hline 75-01-4 & Vinyl Chloride & $\mathbf{X}$ & $1.6 \%$ & $<0.02-0.083$ & 0.08 & \\
\hline $75-25-2$ & Bromoform & & $0.0 \%$ & $<0.032-<0.89$ & & \\
\hline $75-27-4$ & Bromodichloromethane & & $0.0 \%$ & $<0.06-<0.39$ & & \\
\hline 75-34-3 & 1,1-Dichloroethane (Ethylidene Dichloride) & $\mathbf{X}$ & $0.0 \%$ & $<0.035-<0.08$ & & \\
\hline 75-35-4 & 1,1-Dichloroethene (Vinylidene Chloride) & $\mathbf{X}$ & $0.8 \%$ & $<0.02-<0.09 *$ & & \\
\hline $760-21-4$ & 2-Ethyl-1-butene & & $8.5 \%$ & $0.038-0.17$ & 0.09 & 0.03 \\
\hline $7642-04-8$ & cis-2-Octene & & $1.6 \%$ & $<0.083-<0.3$ & & \\
\hline $7642-10-6$ & cis-3-Heptene & & $6.2 \%$ & $0.076-0.62$ & 0.19 & 0.19 \\
\hline 78-87-5 & 1,2-Dichloropropane (Propylene Dichloride) & $\mathbf{X}$ & $\mathbf{0 . 0 \%}$ & $<0.057-<0.11$ & & \\
\hline $79-00-5$ & 1,1,2-Trichloroethane & $\mathbf{X}$ & $0.8 \%$ & $<0.07-<0.12$ & & \\
\hline 79-01-6 & Trichloroethene (Trichloroethylene) & $\mathbf{X}$ & $8.5 \%$ & $0.02-0.23$ & 0.08 & 0.07 \\
\hline $79-34-5$ & 1,1,2,2-Tetrachloroethane & & $5.4 \%$ & $0.036-0.15$ & 0.08 & 0.04 \\
\hline $872-05-9$ & 1-Decene & & $0.8 \%$ & $<0.19-<1.9$ & & \\
\hline $95-13-6$ & Indene & & $3.9 \%$ & $0.015-0.047$ & 0.02 & 0.01 \\
\hline $95-49-8$ & $\begin{array}{l}\text { 2-Chlorotoluene (measured as 2- and 3- } \\
\text { Chlorotoluene) }\end{array}$ & & $0.0 \%$ & $<0.34-<3.2$ & & \\
\hline $95-50-1$ & 1,2-Dichlorobenzene & & $6.2 \%$ & $0.027-0.35$ & 0.17 & 0.12 \\
\hline $98-82-8$ & Isopropylbenzene (Cumene) & & $9.3 \%$ & $0.02-0.07$ & 0.04 & 0.01 \\
\hline $98-06-6$ & tert-Butylbenzene & & $0.0 \%$ & $<0.29-<2.2$ & & \\
\hline
\end{tabular}




\subsection{Comparison with National Values}

To gain a perspective of the significance of our measurements, it is instructive to compare our measurements with available typical national values. This section provides that information in three subsections for particles, inorganic elements, and VOCs. Much of the information on typical concentrations came from the ATSDR [ATSDR-TPIS], EPA [EPA-HENHAP], the California Air Resources Board [CARB], and the 1999/2000 Urban Air Toxics Monitoring Program Report (UATMP) [EPA2001]. Other references for such information are provided in the individual sections below.

\subsection{Particulate Matter}

The EPA "Air Trends" web site for particles [EPA-ATPM] and a closely related site [EPAATPMMD] provide a wealth of information about airborne particulate matter. Those web sites provide a number of comparisons for particulate matter that can provide a point of reference for our particulate measurements. For example, the annual average $\mathrm{PM}_{10}$ at 770 sites around the US has declined from about $28 \mu \mathrm{g} / \mathrm{m}^{3}$ in 1992 to about $23 \mu \mathrm{g} / \mathrm{m}^{3}$ in 2001 . As of 2001 about $90 \%$ of those 770 stations had annual averages less than about $34 \mu \mathrm{g} / \mathrm{m}^{3}$, and about $10 \%$ had annual averages less than $15 \mu \mathrm{g} / \mathrm{m}^{3}$. The long-term average $\mathrm{PM}_{10}$ we measured was $18.8 \mu \mathrm{g} / \mathrm{m}^{3}$. Thus, the Los Alamos area is lower than the national average.

The EPA data show that $\mathrm{PM}_{2.5}$ measurements average about $11 \mu \mathrm{g} / \mathrm{m}^{3}$ in the rural Eastern US and about $4 \mu \mathrm{g} / \mathrm{m}^{3}$ in the rural Western US. Urban $\mathrm{PM}_{2.5}$ is substantially higher. For example, the San Joaquin Valley (Sacramento, CA) averages a $\mathrm{PM}_{2.5}$ of about $32 \mu \mathrm{g} / \mathrm{m}^{3}$. Phoenix and Dallas have annual averages of about $13 \mu \mathrm{g} / \mathrm{m}^{3}$, while El Paso has an average over $22 \mu \mathrm{g} / \mathrm{m}^{3}$. Our $\mathrm{PM}_{2.5}$ measurements at LANL averaged $7.9 \mu \mathrm{g} / \mathrm{m}^{3}$, low for a metropolitan area and a little higher than for the typical rural Western US.

Thus, we conclude that, since Los Alamos is a rural area with some urban characteristics, our particulate measurements are consistent with what we would expect, based on national averages.

\subsection{Inorganic Elements}

Table 8-1 compares our inorganic elemental measurements to some national values. HAPs are shown in bold. Again, note that these inorganic results are in $\mathbf{n g} / \mathbf{m}^{\mathbf{3}}$. Generally, our inorganic elemental results appear to be typical to low, sometimes very low (antimony, arsenic, cadmium, chromium, lead, nickel, and selenium). Los Alamos appears to be a little higher than the typical average for barium, beryllium, iron, and vanadium. However, these four elements are low compared to urban areas. 
Table 8-1. LANL Inorganic Measurements Compared to Typical National Values

\begin{tabular}{|c|c|c|c|}
\hline Symbol & Name & Typical National Value $\left(\mathrm{ng} / \mathrm{m}^{3}\right)$ & LANL Avg (ng/m $\left.{ }^{3}\right)$ \\
\hline Sb & Antimony & 1-170 (1-500 range) & 0.46 \\
\hline As & Arsenic & 20-30 urban (0.4-30 range) & 0.42 \\
\hline $\mathrm{Ba}$ & Barium & 9 (1.5-950 range) & 21 \\
\hline $\mathbf{B e}$ & Beryllium & 0.03 typically, 0.2 urban $(<5)$ & 0.06 \\
\hline $\mathbf{C d}$ & Cadmium & $<1-40$, urban higher & 0.08 \\
\hline $\mathrm{Ce}$ & Cerium & No data found & 2.0 \\
\hline $\mathbf{C r}$ & Chromium & 10-30 & 1.9 \\
\hline Co & Cobalt & $<1-2,0.4$ typically & $\mathbf{0 . 3 3}$ \\
\hline $\mathrm{Cu}$ & Copper & $1-200$ (in some cases, 3-7000) & 47 \\
\hline $\mathrm{Fe}$ & Iron & $50-90$ rural, urban 1300 & 760 \\
\hline $\mathbf{P b}$ & Lead & $<50$ typically, (100-300 range) & 2.7 \\
\hline Mn & Manganese & 20 (5-33 range) & 21 \\
\hline $\mathrm{Nd}$ & Neodymium & No data found & 0.76 \\
\hline $\mathbf{N i}$ & Nickel & $7-12$ (1-3 remote areas, 5-35 urban) & 1.1 \\
\hline Se & Selenium & $<10(0.1-10$ range $)$ & 0.36 \\
\hline $\mathrm{Ag}$ & Silver & $<1$ & 0.10 \\
\hline $\mathrm{Sr}$ & Strontium & No data found & 8.1 \\
\hline $\mathrm{Tl}$ & Thallium & $<1$ & 0.02 \\
\hline $\mathrm{V}$ & Vanadium & $0.1-1,64$ where hi- $\mathrm{V}$ fuels used & 2.0 \\
\hline $\mathrm{Zn}$ & Zinc & $10-100$ rural, $100-500$ urban & 19 \\
\hline
\end{tabular}

HAPs are shown in bold.

\subsection{Volatile Organic Compounds}

Tables 8-2, 8-3, and 8-4 compare our VOC measurements to some national values. Table 8-2 provides information for those VOCs that we frequently detected, that is, in greater than $50 \%$ of the samples. Table 8-3 is for those VOCs we detected in $10 \%$ to $50 \%$ of the samples. Table 8-4 is for those VOCs that we detected in less than $10 \%$ of the samples. In Table 8-4, "ND" means "none detected." In all three tables, HAPs are shown in bold.

As shown in these tables, the NonRadNET average concentrations are generally lower to much lower than the comparable national values. It is notable that benzene, toluene, and the xylenes, the primary components of gasoline, are well below typical national values. Those few NonRadNET averages that seem to be higher than national values are

- benzaldehyde

- butyraldehyde

- acetone

- acetaldehyde (HAP)

All four of these VOCs have a naturally occurring component. Acetone and acetaldehyde are also found in fuel exhausts. Benzaldehyde and butyraldehyde are solvents. Benzaldehyde, acetone, and acetaldehyde appear to be roughly three times the few comparable national values 
we were able to find. Butyraldehyde is just slightly higher than the comparable national value. Neither benzaldehyde nor butyraldehyde is used at the Laboratory. Acetone is used at the Laboratory in just over one-ton quantities each year. Less than 100 pounds of acetaldehyde was used at the Laboratory in 2002. None was used in 2001. 
Table 8-2. Comparison of National Values With VOCs Detected In $>\mathbf{5 0 \%}$ of NonRadNET Samples

\begin{tabular}{|c|c|c|c|c|c|c|}
\hline \multirow{2}{*}{ CAS \# } & \multirow{2}{*}{ Name } & \multirow{2}{*}{$\begin{array}{l}\text { LANL } \\
\left(\mu \mathrm{g} / \mathrm{m}^{3}\right)\end{array}$} & \multicolumn{4}{|c|}{ Typical Airborne Levels $\left(\mu \mathrm{g} / \mathrm{m}^{3}\right)$} \\
\hline & & & General & Urban & Rural & UATMP \\
\hline $100-41-4$ & Ethyl Benzene & 0.35 & & 1.7 & 0.6 & 1 \\
\hline $100-42-5$ & Styrene & 0.07 & 0.8 & $0.3-3.8$ & $0.3-0.34$ & 0.8 \\
\hline $100-52-7$ & Benzaldehyde & 1.1 & & & & 0.4 \\
\hline $103-65-1$ & n-Propylbenzene & 0.09 & & & & 3.9 \\
\hline $106-42-3$ & p-Xylene (including 108-38-3 m-Xylene) & 1.1 & 8.7 & $3-380$ & & 2.7 \\
\hline $106-97-8$ & Butane & 12 & & & & 26 \\
\hline $106-98-9$ & 1-Butene & 0.4 & & & & 4.6 \\
\hline $106-99-0$ & 1,3-Butadiene & 0.1 & 0.7 & & & 0.3 \\
\hline $107-39-1$ & 2,4,4-Trimethyl-1-pentene & 0.07 & no data & no data & no data & no data \\
\hline $107-83-5$ & Isohexane (2-Methylpentane) & 1.3 & & & & 12.3 \\
\hline $108-08-7$ & 2,4-Dimethylpentane & 0.2 & & & & 5.2 \\
\hline $108-67-8$ & 1,3,5-Trimethylbenzene & 0.11 & & & & 6.5 \\
\hline $108-87-2$ & Methylcyclohexane & 0.16 & & & & 6.2 \\
\hline $108-88-3$ & Toluene & 2.5 & 10 & 11 & 1.3 & 5.6 \\
\hline $109-66-0$ & Pentane & 3.1 & & & & 35 \\
\hline 109-67-1 & 1-Pentene & 0.29 & & & & 1.8 \\
\hline $110-54-3$ & Hexane & 0.81 & 13 & & & 50 \\
\hline $110-82-7$ & Cyclohexane & 0.26 & & & & 27 \\
\hline $111-65-9$ & n-Octane & 0.15 & & & & 0.5 \\
\hline $111-84-2$ & n-Nonane & 0.12 & & & & 6 \\
\hline $1120-21-4$ & n-Undecane & 0.07 & & & & 19.5 \\
\hline $115-07-1$ & Propylene & 0.48 & & & & 1.7 \\
\hline $123-72-8$ & Butyraldehyde & 1.2 & & & & 0.8 \\
\hline $124-18-5$ & n-Decane & 0.07 & & & & 8.3 \\
\hline $142-82-5$ & Heptane & 0.25 & & & & 5.6 \\
\hline $287-92-3$ & Cyclopentane & 0.22 & & & & 2 \\
\hline $31394-54-4$ & Isoheptane (2-Methylhexane) & 0.5 & & & & 5.4 \\
\hline $4050-45-7$ & trans-2-Hexene & 0.09 & & & & 1.2 \\
\hline
\end{tabular}


Table 8-2 (cont.)

\begin{tabular}{|c|c|c|c|c|c|c|}
\hline \multirow{2}{*}{ CAS \# } & \multirow{2}{*}{ Name } & \multirow{2}{*}{$\begin{array}{c}\text { LANL } \\
\left(\mu \mathrm{g} / \mathrm{m}^{3}\right)\end{array}$} & \multicolumn{4}{|c|}{ Typical Airborne Levels $\left(\mu \mathrm{g} / \mathrm{m}^{3}\right)$} \\
\hline & & & General & Urban & Rural & UATMP \\
\hline $463-82-1$ & Neopentane & 0.1 & no data & no data & no data & no data \\
\hline $513-35-9$ & 2-Methyl-2-butene & 0.58 & & & & 3.4 \\
\hline $526-73-8$ & 1,2,3-Trimethylbenzene & 0.08 & & & & 7.3 \\
\hline $540-84-1$ & 2,2,4-Trimethylpentane (Isooctane) & 0.42 & & 22.5 & & 10 \\
\hline $56-23-5$ & Carbon Tetrachloride & 0.73 & 1.2 & & 1 & 0.4 \\
\hline $564-02-3$ & 2,2,3-Trimethylpentane & 0.05 & & & & 3.9 \\
\hline $565-59-3$ & 2,3-Dimethylpentane & 0.35 & & & & 7 \\
\hline $565-75-3$ & 2,3,4-Trimethylpentane & 0.34 & & & & 5.4 \\
\hline $589-34-4$ & 3-Methylhexane & 0.49 & & & & 9.3 \\
\hline $589-81-1$ & 3-Methylheptane & 0.09 & & & & 3.2 \\
\hline $590-18-1$ & cis-2-Butene & 0.26 & & & & 1.9 \\
\hline $592-13-2$ & 2,5-Dimethylhexane & 0.06 & no data & no data & no data & no data \\
\hline $592-27-8$ & 2-Methylheptane & 0.2 & & & & 3.2 \\
\hline $592-41-6$ & 1-Hexene & 0.1 & & & & 2.3 \\
\hline $592-76-7$ & 1-Heptene & 0.2 & & & & 1.8 \\
\hline $611-14-3$ & 2-Ethyltoluene (o-Ethyltoluene) & 0.09 & & & & 5.8 \\
\hline $620-14-4$ & 3-Ethyltoluene (m-Ethyltoluene) & 0.23 & & & & 10.9 \\
\hline $622-96-8$ & 4-Ethyltoluene (p-Ethyltoluene) & 0.12 & & & & 5.9 \\
\hline $624-64-6$ & trans-2-Butene & 0.26 & & & & 1.5 \\
\hline $625-27-4$ & 2-Methyl-2-pentene & 0.1 & no data & no data & no data & no data \\
\hline $627-20-3$ & cis-2-Pentene & 0.29 & & & & 2 \\
\hline $64-17-5$ & Ethanol (Ethyl alcohol) & 23 & no data & no data & no data & no data \\
\hline $646-04-8$ & trans-2-Pentene & 0.5 & & & & 2.4 \\
\hline $66-25-1$ & Hexanal & 1 & no data & no data & no data & no data \\
\hline $67-56-1$ & Methanol (Methyl alcohol) & 10.8 & 23.1 & & & \\
\hline $67-63-0$ & 2-Propanol (Isopropyl Alcohol) & 0.42 & no data & no data & no data & no data \\
\hline $67-64-1$ & Acetone (2-Propanone) & 12 & & & & 4.4 \\
\hline $67-66-3$ & Chloroform & 0.04 & 0.2 & 2.7 & & 0.1 \\
\hline $71-43-2$ & Benzene & 1.3 & 2 & 50 & $0.3-54$ & 2 \\
\hline
\end{tabular}


Table 8-2 (cont.)

\begin{tabular}{|c|c|c|c|c|c|c|}
\hline \multirow{2}{*}{ CAS \# } & \multirow{2}{*}{ Name } & \multirow{2}{*}{$\begin{array}{c}\text { LANL } \\
\left(\mu g / m^{3}\right)\end{array}$} & \multicolumn{4}{|c|}{ Typical Airborne Levels $\left(\mu \mathrm{g} / \mathrm{m}^{3}\right)$} \\
\hline & & & General & Urban & Rural & UATMP \\
\hline $71-55-6$ & 1,1,1-Trichloroethane (Methyl Chloroform) & 0.21 & 5.6 & & & 0.2 \\
\hline $74-83-9$ & Bromomethane (Methyl Bromide) & 0.04 & $<0.1$ & 9 & & 0.3 \\
\hline 74-84-0 & Ethane & 5.4 & & & & 13 \\
\hline $74-85-1$ & Ethylene & 1.3 & & & & 6.5 \\
\hline $74-86-2$ & Acetylene & 1.1 & & & & 2.5 \\
\hline $74-87-3$ & Freon 40 Chloromethane (Methyl Chloride) & 1.1 & 1.6 & & & 1.4 \\
\hline $74-98-6$ & Propane & 3.4 & & & & 20 \\
\hline $75-05-8$ & Acetonitrile & 0.37 & & 0.05 & & 0.8 \\
\hline $75-07-0$ & Acetaldehyde & 8.1 & 2.5 & & $<1$ & 2.6 \\
\hline $75-09-2$ & Methylene Chloride (Dichloromethane) & 0.25 & 5.6 & & & 10 \\
\hline $75-28-5$ & Isobutane & 3.7 & & & & 9.6 \\
\hline $75-45-6$ & Freon 22 (Chlorodifluoromethane) & 1.4 & no data & no data & no data & no data \\
\hline $75-69-4$ & Freon 11 (Trichlorofluoromethane) & 1.65 & & & & 1.9 \\
\hline $75-71-8$ & Freon 12 (Dichlorodifluoromethane) & 2.96 & & & & 3.4 \\
\hline $75-83-2$ & 2,2-Dimethylbutane (Neohexane) & 0.22 & & & & 3.4 \\
\hline $76-13-1$ & Freon 113 (1,1,2-Trichloro-1,2,2-trifluoroethane) & 0.66 & & & & 0.6 \\
\hline $76-14-2$ & Freon 114 (1,2-Dichlorotetrafluoroethane) & 0.1 & no data & no data & no data & no data \\
\hline $763-29-1$ & 2-Methyl-1-pentene & 0.08 & & & & 1.3 \\
\hline $78-78-4$ & 2-Methylbutane (Isopentane) & 9 & & & & 48 \\
\hline $78-79-5$ & Isoprene & 0.2 & & & & 2.3 \\
\hline $78-93-3$ & 2-Butanone (Methyl Ethyl Ketone) & 1.1 & 1.4 & & & 6 \\
\hline $79-29-8$ & 2,3-Dimethylbutane & 0.33 & & & & 5.2 \\
\hline $80-56-8$ & alpha-Pinene & 1 & & & & $5-26$ \\
\hline $811-97-2$ & Halocarbon 134A & 0.24 & no data & no data & no data & no data \\
\hline $95-47-6$ & o-Xylene & 0.43 & 2.6 & $3-380$ & & 1.2 \\
\hline $95-63-6$ & 1,2,4-Trimethylbenzene & 0.31 & & & & 16.7 \\
\hline 96-14-0 & 3-Methylpentane & 0.7 & & & & 9 \\
\hline $96-37-7$ & Methylcyclopentane & 0.4 & & & & 5.6 \\
\hline
\end{tabular}


Table 8-3. Comparison of National Values With VOCs Detected in $10 \%$ to $50 \%$ of NonRadNET Samples

\begin{tabular}{|c|c|c|c|c|c|c|}
\hline \multirow{2}{*}{ CAS } & \multirow{2}{*}{ Name } & \multirow{2}{*}{$\begin{array}{l}\text { LANL } \\
\left(\mu \mathrm{g} / \mathrm{m}^{3}\right)\end{array}$} & \multicolumn{4}{|c|}{ Typical Airborne Levels $\left(\mu \mathrm{g} / \mathrm{m}^{3}\right)$} \\
\hline & & & General & Urban & Rural & UATMP \\
\hline $106-46-7$ & 1,4-Dichlorobenzene (p-Dichlorobenzene) & 0.1 & 1 & & & 0.4 \\
\hline $108-05-4$ & Vinyl Acetate & 1.7 & no data & no data & no data & no data \\
\hline $108-10-1$ & 4-Methyl-2-pentanone (Methyl isobutyl ketone) & 0.27 & & & & 0.8 \\
\hline $108-90-7$ & Chlorobenzene & 0.04 & 0.14 & & & 0.1 \\
\hline $111-66-0$ & 1-Octene & 0.08 & & & & 1.2 \\
\hline 111-71-7 & Heptanal & 0.95 & no data & no data & no data & no data \\
\hline $120-82-1$ & 1,2,4-Trichlorobenzene & 0.22 & & 1.3 & 0.8 & 0.2 \\
\hline $124-11-8$ & 1-Nonene & 0.08 & & & & 2.2 \\
\hline $127-18-4$ & $\begin{array}{l}\text { Tetrachloroethene (Perchloroethylene, } \\
\text { Tetrachloroethylene) }\end{array}$ & 0.13 & 4 & 5.4 & 1 & 0.4 \\
\hline $127-91-3$ & beta-Pinene & 0.15 & & & & 12.3 \\
\hline $138-86-3$ & Limonene & 0.12 & no data & no data & no data & no data \\
\hline $142-29-0$ & Cyclopentene & 0.09 & & & & 1.5 \\
\hline $3522-94-9$ & 2,2,5-Trimethylhexane & 0.04 & no data & no data & no data & no data \\
\hline 496-11-7 & Indan & 0.04 & no data & no data & no data & no data \\
\hline $563-45-1$ & 3-Methyl-1-butene & 0.27 & 1.2 & & & 0.4 \\
\hline $691-38-3$ & cis/trans-4-Methyl-2-pentene & 0.11 & no data & no data & no data & no data \\
\hline 693-89-0 & 1-Methylcyclopentene & 0.11 & no data & no data & no data & no data \\
\hline $71-36-3$ & 1-Butanol (n-Butyl Alcohol) & 0.8 & no data & no data & no data & no data \\
\hline $75-00-3$ & Chloroethane (Ethyl Chloride) Freon 160 & 0.12 & 55 & & & 0.1 \\
\hline $75-43-4$ & Freon 21 (Dichlorofluoromethane) & 0.03 & & & & 2.9 \\
\hline $7642-09-3$ & cis-3-Hexene & 0.09 & no data & no data & no data & no data \\
\hline $7688-21-3$ & cis-2-Hexene & 0.07 & & & & 1.7 \\
\hline $821-95-4$ & 1-Undecene & 0.27 & & & & 4.2 \\
\hline $87-68-3$ & Hexachlorobutadiene & 0.35 & 0.3 & & & 0.3 \\
\hline $91-20-3$ & Naphthalene & 0.11 & 1 & $0.5-1$ & & \\
\hline $922-62-3$ & cis-3-Methyl-2-pentene & 0.1 & no data & no data & no data & no data \\
\hline $99-87-6$ & 4-Isopropyltoluene (p-Cymeme) & 0.08 & no data & no data & no data & no data \\
\hline
\end{tabular}


Table 8-4. Comparison of National Values With VOCs Detected in $<10 \%$ of NonRadNET Samples

\begin{tabular}{|c|c|c|c|c|c|c|}
\hline \multirow{2}{*}{ CAS } & \multirow{2}{*}{ Name } & \multirow{2}{*}{$\begin{array}{c}\text { LANL } \\
\left(\mu g / \mathbf{m}^{3}\right)\end{array}$} & \multicolumn{4}{|c|}{ Typical Airborne Levels $\left(\mu \mathrm{g} / \mathrm{m}^{3}\right)$} \\
\hline & & & General & Urban & Rural & UATMP \\
\hline $100-44-7$ & Chlorotoluene (Benzyl Chloride) & ND* & no data & no data & no data & no data \\
\hline $10061-01-5$ & cis-1,3-Dichloropropene & ND & & & & ND \\
\hline $10061-02-6$ & trans-1,3-Dichloropropene & ND & & & & ND \\
\hline $104-51-8$ & n-Butylbenzene & 0.05 & no data & no data & no data & no data \\
\hline $105-05-5$ & 1,4-Diethylbenzene (p-Diethylbenzene ${ }^{\circ}$ & 0.04 & & & & 6.3 \\
\hline $106-43-4$ & 4-Chlorotoluene & ND & no data & no data & no data & no data \\
\hline $106-93-4$ & Ethylene Dibromide (1,2-Dibromoethane) & 0.08 & 1.8 & & & \\
\hline $107-06-2$ & 1, 2-Dichloroethane (Ethylene Dichloride) & 0.03 & & $0.4-6$ & & 0.1 \\
\hline $107-13-1$ & Acrylonitrile & ND & & 0.7 & & 0.4 \\
\hline $107-40-4$ & 2,4,4-Trimethyl-2-pentene & ND & no data & no data & no data & no data \\
\hline $108-41-8$ & 3-Chlorotoluene (measured as 2- and 3-Chlorotoluene) & ND & no data & no data & no data & no data \\
\hline $110-83-8$ & Cyclohexene & 0.04 & no data & no data & no data & no data \\
\hline $123-91-1$ & 1,4-Dioxane (1,4-Diethyloxide) & ND & 0.4 & & & \\
\hline $124-48-1$ & Dibromochloromethane & ND & & & & 0.2 \\
\hline $126-99-8$ & 2-Chloro-1,3-butadiene (Chloroprene) & ND & & 0.3 & & 0.2 \\
\hline $141-32-2$ & Butyl Acrylate & ND & no data & no data & no data & no data \\
\hline $141-93-5$ & 1,3-Diethylbenzene (m-Diethylbenzene) & 0.03 & & & & 8.9 \\
\hline $14686-13-6$ & trans-2-Heptene & 0.07 & no data & no data & no data & no data \\
\hline $14686-14-7$ & trans-3-Heptene & 0.15 & no data & no data & no data & no data \\
\hline $156-59-2$ & cis-1,2 Dichloroethene & ND & & & & 0.1 \\
\hline $156-60-5$ & trans-1,2-Dichloroethene & ND & no data & no data & no data & no data \\
\hline 1634-04-4 & Methyl tert-Butyl Ether & 0.05 & 1 & 6 & & 1 \\
\hline $2198-23-4$ & 4-Nonene & $\mathrm{ND}$ & no data & no data & no data & no data \\
\hline $538-93-2$ & Isobutylbenzene & ND & no data & no data & no data & no data \\
\hline $541-73-1$ & 1,3-Dichlorobenzene & 0.14 & 1.2 & & & 0.4 \\
\hline $591-49-1$ & 1-Methylcyclohexene & ND & no data & no data & no data & no data \\
\hline $593-60-2$ & Vinyl bromide & ND & no data & no data & no data & no data \\
\hline $60-29-7$ & Diethyl ether & $\mathrm{ND}$ & no data & no data & no data & no data \\
\hline $691-37-2$ & 4-Methyl-1-pentene & 0.17 & & & & ND \\
\hline
\end{tabular}

HAPS shown in bold 
Table 8-4 (cont.)

\begin{tabular}{|c|c|c|c|c|c|c|}
\hline \multirow{2}{*}{ CAS \# } & \multirow{2}{*}{ Name } & \multirow{2}{*}{$\begin{array}{c}\text { LANL } \\
\left(\mu \mathrm{g} / \mathrm{m}^{3}\right)\end{array}$} & \multicolumn{4}{|c|}{ Typical Airborne Levels $\left(\mu \mathrm{g} / \mathrm{m}^{3}\right)$} \\
\hline & & & General & Urban & Rural & UATMP \\
\hline $71-23-8$ & 1-Propanol & 1.5 & no data & no data & no data & no data \\
\hline $74-97-5$ & Bromochloromethane & ND & & & & 25.2 \\
\hline $75-01-4$ & Vinyl Chloride & 0.08 & 1 & & & 0.07 \\
\hline $75-25-2$ & Bromoform & ND & & 2.3 & & 0.4 \\
\hline $75-27-4$ & Bromodichloromethane & ND & & & & 0.2 \\
\hline $75-34-3$ & 1,1-Dichloroethane (Ethylidene Dichloride) & ND & 0.2 & $0.4-6$ & & 0.14 \\
\hline $75-35-4$ & 1,1-Dichloroethene (Vinylidene Chloride) & ND & $<0.4$ & & & 0.15 \\
\hline $760-21-4$ & 2-Ethyl-1-butene & 0.09 & & & & ND \\
\hline $7642-04-8$ & cis-2-Octene & ND & no data & no data & no data & no data \\
\hline $7642-10-6$ & cis-3-Heptene & 0.19 & no data & no data & no data & no data \\
\hline $78-87-5$ & 1,2-Dichloropropane (Propylene Dichloride) & ND & & 0.75 & & 0.17 \\
\hline $79-00-5$ & 1,1,2-Trichloroethane & ND & $0.06-0.3$ & 0.3 & & 0.16 \\
\hline $79-01-6$ & Trichloroethene (Trichloroethylene) & 0.08 & $0.01-4$ & & & 2 \\
\hline $79-34-5$ & 1,1,2,2-Tetrachloroethane & 0.08 & 0.03 & $1-60$ & $0.4-1$ & 0.2 \\
\hline $872-05-9$ & 1-Decene & ND & & & & 2.4 \\
\hline $95-13-6$ & Indene & 0.02 & no data & no data & no data & no data \\
\hline $95-49-8$ & 2-Chlorotoluene (measured as 2- and 3-Chlorotoluene) & ND & no data & no data & no data & no data \\
\hline $95-50-1$ & 1,2-Dichlorobenzene & 0.17 & & & & 0.2 \\
\hline $98-06-6$ & tert-Butylbenzene & ND & no data & no data & no data & no data \\
\hline 98-82-8 & Isopropylbenzene (Cumene) & 0.04 & 1.3 & & & 2 \\
\hline
\end{tabular}

$* \mathrm{ND}=$ None Detected

HAPS shown in bold 


\subsection{Comparision with Exposure Standards}

Unlike radioactive materials, nonradioactive airborne environmental pollutants traditionally have been regulated at the source; that is, emission rates are regulated instead of ambient air concentrations. Consequently, ambient airborne limits for most nonradioactive pollutants do not exist. Therefore, in the absence of ambient airborne standards, we have chosen to compare our measurements with limits for occupational airborne exposure, which do exist for many of these pollutants. We recognize that occupational limits do not apply directly to public exposures; however, we believe the comparison is still instructive. Wherever an Occupational Safety and Health Administration (OSHA) 29CFR1910.1000 [OSHA1910] 8-hour time weighted average (TWA) exists, we have used it. In some cases OSHA has vacated (eliminated) a limit, but we have chosen to use it in the absence of other limits. If there was no known OSHA limit, we used American Conference of Governmental Industrial Hygienists (ACGIH) recommendations listed in some Material Safety Data Sheets (MSDSs). If neither OSHA nor ACGIH listed a value, we used American Industrial Hygiene Association (AIHA) or other standards (such as those of Du Pont) given in some of the MSDS. Finally, in the absence of any known US standard or recommendation, we used any limits specified in foreign standards from 16 countries [IPCS].

\subsection{Particulate Matter}

The EPA has established National Ambient Air Quality Standards [EPA] for $\mathrm{PM}_{10}$ and $\mathrm{PM}_{2.5}$. Additionally, the New Mexico Administrative Code has an ambient air quality standard for TSP. These standards are shown in Table 9-1. Although EPA and New Mexico 24-hour limits exist $\left(150 \mu \mathrm{g} / \mathrm{m}^{3}\right)$, the values in the table are the lower annual average limits, since the LANL mean is a long-term average. These EPA and New Mexico particulate limits are among the few ambient environmental (nonoccupational) limits that exist. The table shows that, even though northern New Mexico could be classed as "dry and dusty," the NonRadNET particulate measurements are below the EPA and New Mexico particulate standards.

Table 9-1. Comparison of NonRadNET Particulate Measurements to EPA and New Mexico Ambient Air Quality Standards

\begin{tabular}{|c|c|c|c|}
\hline $\begin{array}{l}\text { Particle } \\
\text { Type }\end{array}$ & $\begin{array}{c}\text { LANL } \\
\text { Mean } \\
\left(\mu g / m^{3}\right)\end{array}$ & $\begin{array}{l}\text { New } \\
\text { Mexico } \\
\text { Standard* } \\
\left(\mu \mathrm{g} / \mathrm{m}^{3}\right)\end{array}$ & $\begin{array}{l}\text { EPA } \\
\text { Standard } \\
\left(\boldsymbol{\mu g} / \mathrm{m}^{3}\right)\end{array}$ \\
\hline TSP & 52.1 & 60 & None \\
\hline $\mathrm{PM}_{10}$ & 21.6 & None & 50 \\
\hline $\mathrm{PM}_{2.5}$ & 7.9 & None & 15 \\
\hline
\end{tabular}

\subsection{Inorganic Elements}

This section discusses the 20 inorganic elements with reference to OSHA occupational limits and the one EPA ambient air quality standard for lead. Table 9.2 shows the average and maximum values for each of the 20 NonRadNET elements. Recall that we have been expressing these 
measurements in $\mathbf{n g} / \mathrm{m}^{3}$. The table shows that the measured concentrations are generally many orders of magnitude below the OSHA 8-hour TWA occupational limits. EPA has an ambient air quality standard for lead, and the measured values are very low by comparison, about $1 \%$ of the limit for the highest lead value measured during the entire NonRadNET program. The ratio of the OSHA occupational lead value to the EPA ambient air quality standard is 33. If we were to create artificial "environmental" limits by reducing all of the OSHA values by a factor of 33, or even by a factor of 100 , the measured concentrations for the remaining elements still would be a very small fraction of these artificial "environmental" limits.

Table 9-2. Comparison of NonRadNET Elemental Measurements to Limits

\begin{tabular}{|c|c|c|c|c|c|}
\hline Symbol & Name & $\begin{array}{l}\text { LANL } \\
\text { Mean } \\
\left(\mathbf{n g} / \mathbf{m}^{3}\right)\end{array}$ & $\begin{array}{l}\text { LANL } \\
\text { Max } \\
\left(\mathbf{n g} / \mathbf{m}^{3}\right)\end{array}$ & $\begin{array}{l}\text { OSHA* } \\
\left(\mathbf{n g} / \mathbf{m}^{3}\right)\end{array}$ & $\begin{array}{c}\mathbf{E P A}^{\#} \\
\left(\mathbf{n g} / \mathbf{m}^{3}\right)\end{array}$ \\
\hline $\mathrm{Sb}$ & Antimony & 0.46 & 1.4 & 500,000 & None \\
\hline As & Arsenic & 0.42 & 2.15 & 10,000 & None \\
\hline $\mathrm{Ba}$ & Barium & 21 & 110 & 500,000 & None \\
\hline $\mathrm{Be}$ & Beryllium & 0.06 & 0.51 & 2,000 & None \\
\hline $\mathrm{Cd}$ & Cadmium & 0.08 & 0.38 & 5,000 & None \\
\hline $\mathrm{Ce}$ & Cerium & 2.0 & 6.2 & None & None \\
\hline $\mathrm{Cr}$ & Chromium & 1.9 & 10 & 500,000 & None \\
\hline Co & Cobalt & 0.33 & 1.8 & 100,000 & None \\
\hline $\mathrm{Cu}$ & Copper & 47 & 235 & $1,000,000$ & None \\
\hline $\mathrm{Fe}$ & Iron & 760 & 2190 & $10,000,000$ & None \\
\hline $\mathrm{Pb}$ & Lead & 2.7 & 16 & 50,000 & 1,500 \\
\hline $\mathrm{Mn}$ & Manganese & 21 & 122 & $1,000,000$ & None \\
\hline $\mathrm{Nd}$ & Neodymium & 0.76 & 2.3 & None & None \\
\hline $\mathrm{Ni}$ & Nickel & 1.1 & 4.2 & $1,000,000$ & None \\
\hline $\mathrm{Se}$ & Selenium & 0.36 & 0.84 & 200,000 & None \\
\hline $\mathrm{Ag}$ & Silver & 0.10 & 1.14 & 10,000 & None \\
\hline $\mathrm{Sr}$ & Strontium & 8.1 & 41 & None & None \\
\hline $\mathrm{Tl}$ & Thallium & 0.02 & 0.11 & 100,000 & None \\
\hline $\mathrm{V}$ & Vanadium & 2.0 & 12 & 500,000 & None \\
\hline $\mathrm{Zn}$ & Zinc & 19 & 53 & $5,000,000$ & None \\
\hline
\end{tabular}




\subsection{Volatile Organic Compounds}

This section discusses the 160 VOCs with reference to their OSHA (or other) occupational limits, wherever such exist. If OSHA has no current or historical limit, we have used ACGIH, AIHA, and foreign standards. Again, we fully recognize that occupational limits do not apply to ambient environmental exposures. However, in the absence of any such ambient exposure standards, we believe a comparison with occupational standards can be useful.

Using the previous format of dividing the VOCs by their detection frequencies, Tables 9-3 through 9-5 compare the average and maximum measurements with the occupational limits. The most obvious conclusion from scanning through these tables is that the measured values are very small when compared to the occupational limits. In fact, hexachlorobutadiene (CAS \# 87-68-3) in Table 9-4 comes the closest of any of these measurements to its limit. If we divide our maximum measurement for hexachlorobutadiene into its occupational limit (which is foreign; there is no US limit), our maximum is 0.007 of the limit, less than $1 \%$. All of the others are smaller. For those VOCS in Table 9-3 (detected $>50 \%$ of the time), benzaldehyde (CAS \# 10052-7) comes closest to its limit (which OSHA has dropped from the regulations) at 0.0005 of the old limit. 
Table 9-3. Occupational TWAs for NonRadNET VOCs Detected With $>\mathbf{5 0 \%}$ Frequency

\begin{tabular}{|c|c|c|c|c|}
\hline CAS \# & Name & $\begin{array}{c}\text { LANL } \\
\text { Mean } \\
\left(\mu g / \mathbf{m}^{3}\right)\end{array}$ & $\begin{array}{c}\text { LANL } \\
\operatorname{Max} \\
\left(\mu \mathrm{g} / \mathbf{m}^{3}\right)\end{array}$ & $\begin{array}{l}\text { TWA* } \\
\left(\mu \mathrm{g} / \mathbf{m}^{3}\right)\end{array}$ \\
\hline $100-41-4$ & Ethyl Benzene & 0.35 & 1.38 & 442,000 \\
\hline $100-42-5$ & Styrene & 0.07 & 0.23 & 433,000 \\
\hline $100-52-7$ & Benzaldehyde & 1.1 & 4.58 & 8,820 \\
\hline $103-65-1$ & n-Propylbenzene & 0.09 & 0.26 & None \\
\hline $106-42-3$ & p-Xylene (including 108-38-3 m-Xylene) & 1.1 & 4.3 & 442,000 \\
\hline $106-97-8$ & Butane & 12 & 312 & $1,940,000$ \\
\hline $106-98-9$ & 1-Butene & 0.4 & 5.4 & None \\
\hline $106-99-0$ & 1,3-Butadiene & 0.1 & 0.36 & 2,250 \\
\hline $107-39-1$ & 2,4,4-Trimethyl-1-pentene & 0.07 & 0.19 & None \\
\hline $107-83-5$ & Isohexane (2-Methylpentane) & 1.3 & 24 & $1,790,000$ \\
\hline $108-08-7$ & 2,4-Dimethylpentane & 0.2 & 2.6 & None \\
\hline $108-67-8$ & 1,3,5-Trimethylbenzene & 0.11 & 0.40 & 125,000 \\
\hline $108-87-2$ & Methylcyclohexane & 0.16 & 1.56 & $2,000,000$ \\
\hline $108-88-3$ & Toluene & 2.5 & 13 & 766,000 \\
\hline $109-66-0$ & Pentane & 3.1 & 69 & $2,950,000$ \\
\hline $109-67-1$ & 1-Pentene & 0.29 & 4.9 & None \\
\hline $110-54-3$ & Hexane & 0.81 & 13.5 & 180,000 \\
\hline $110-82-7$ & Cyclohexane & 0.26 & 3.5 & $1,050,000$ \\
\hline $111-65-9$ & n-Octane & 0.15 & 0.56 & $2,350,000$ \\
\hline $111-84-2$ & n-Nonane & 0.12 & 2.4 & $1,066,000$ \\
\hline $1120-21-4$ & n-Undecane & 0.07 & 0.27 & None \\
\hline $115-07-1$ & Propylene & 0.48 & 1.7 & $17,500,000$ \\
\hline $123-72-8$ & Butyraldehyde & 1.2 & 12.6 & 64,000 \\
\hline $124-18-5$ & n-Decane & 0.07 & 0.19 & 350,000 \\
\hline $142-82-5$ & Heptane & 0.25 & 2.4 & $1,668,000$ \\
\hline $287-92-3$ & Cyclopentane & 0.22 & 4.2 & $1,746,000$ \\
\hline $31394-54-4$ & Isoheptane (2-Methylhexane) & 0.5 & 7.2 & None \\
\hline $4050-45-7$ & trans-2-Hexene & 0.09 & 0.97 & None \\
\hline
\end{tabular}

HAPs are shown in bold. 
Table 9-3 (cont.)

\begin{tabular}{|c|c|c|c|c|}
\hline CAS \# & Name & $\begin{array}{c}\text { LANL } \\
\text { Mean } \\
\left(\mu g / \mathbf{m}^{3}\right)\end{array}$ & $\begin{array}{c}\text { LANL } \\
\operatorname{Max} \\
\left(\mu \mathrm{g} / \mathbf{m}^{3}\right)\end{array}$ & $\begin{array}{l}\text { TWA* } \\
\left(\mu \mathrm{g} / \mathbf{m}^{3}\right)\end{array}$ \\
\hline $463-82-1$ & Neopentane & 0.1 & 1.4 & $1,800,000$ \\
\hline $526-73-8$ & 1,2,3-Trimethylbenzene & 0.08 & 0.32 & 125,000 \\
\hline $540-84-1$ & 2,2,4-Trimethylpentane (Isooctane) & 0.42 & 4.3 & $1,425,000$ \\
\hline $56-23-5$ & Carbon Tetrachloride & 0.73 & 1.0 & 154,000 \\
\hline $564-02-3$ & 2,2,3-Trimethylpentane & 0.05 & 0.31 & None \\
\hline $565-59-3$ & 2,3-Dimethylpentane & 0.35 & 3.8 & None \\
\hline $565-75-3$ & 2,3,4-Trimethylpentane & 0.34 & 1.0 & None \\
\hline $589-34-4$ & 3-Methylhexane & 0.49 & 4.2 & None \\
\hline $589-81-1$ & 3-Methylheptane & 0.09 & 0.41 & None \\
\hline $590-18-1$ & cis-2-Butene & 0.26 & 6.7 & None \\
\hline $592-13-2$ & 2,5-Dimethylhexane & 0.06 & 0.34 & None \\
\hline $592-27-8$ & 2-Methylheptane & 0.2 & 2.0 & None \\
\hline $592-41-6$ & 1-Hexene & 0.1 & 0.81 & 175,000 \\
\hline $592-76-7$ & 1-Heptene & 0.2 & 1.7 & None \\
\hline $611-14-3$ & 2-Ethyltoluene (o-Ethyltoluene) & 0.09 & 0.34 & None \\
\hline $620-14-4$ & 3-Ethyltoluene (m-Ethyltoluene) & 0.23 & 0.95 & None \\
\hline $622-96-8$ & 4-Ethyltoluene (p-Ethyltoluene) & 0.12 & 0.42 & None \\
\hline $624-64-6$ & trans-2-Butene & 0.26 & 6.7 & None \\
\hline $625-27-4$ & 2-Methyl-2-pentene & 0.1 & 1.18 & None \\
\hline $627-20-3$ & cis-2-Pentene & 0.29 & 5.53 & None \\
\hline $64-17-5$ & Ethanol (Ethyl alcohol) & 23 & 89.8 & $1,900,000$ \\
\hline $646-04-8$ & trans-2-Pentene & 0.5 & 10.9 & None \\
\hline $66-25-1$ & Hexanal & 1 & 12.1 & None \\
\hline $67-56-1$ & Methanol (Methyl alcohol) & 10.8 & 69.6 & 260,000 \\
\hline $67-63-0$ & 2-Propanol (Isopropyl Alcohol) & 0.42 & 2.3 & 980,000 \\
\hline $67-64-1$ & Acetone (2-Propanone) & 12 & 64.6 & $2,400,000$ \\
\hline $67-66-3$ & Chloroform & 0.04 & 0.49 & 240,000 \\
\hline $71-43-2$ & Benzene & 1.3 & 10.3 & 33,000 \\
\hline $71-55-6$ & 1,1,1-Trichloroethane (Methyl Chloroform) & 0.21 & 0.80 & $1,900,000$ \\
\hline
\end{tabular}

HAPs are shown in bold. 
Table 9-3 (cont.)

\begin{tabular}{|c|c|c|c|c|}
\hline CAS \# & Name & $\begin{array}{c}\text { LANL } \\
\text { Mean } \\
\left(\mu g / m^{3}\right)\end{array}$ & $\begin{array}{c}\text { LANL } \\
\text { Max } \\
\left(\mu g / \mathbf{m}^{3}\right)\end{array}$ & $\begin{array}{l}\text { TWA* } \\
\left(\mu g / \mathbf{m}^{3}\right)\end{array}$ \\
\hline $74-83-9$ & Bromomethane (Methyl Bromide) & 0.04 & 0.24 & 80,000 \\
\hline $74-84-0$ & Ethane & 5.4 & 26.2 & $12,500,000$ \\
\hline $74-87-3$ & Freon 40 Chloromethane (Methyl Chloride) & 1.1 & 1.7 & 420,000 \\
\hline $74-98-6$ & Propane & 3.4 & 27.3 & $1,800,000$ \\
\hline $75-05-8$ & Acetonitrile & 0.37 & 1.1 & 70,000 \\
\hline $75-07-0$ & Acetaldehyde & 8.1 & 40.4 & 360,000 \\
\hline $75-09-2$ & Methylene Chloride (Dichloromethane) & 0.25 & 2.3 & 88,000 \\
\hline $75-28-5$ & Isobutane & 3.7 & 107 & $1,936,000$ \\
\hline $75-45-6$ & Freon 22 (Chlorodifluoromethane) & 1.4 & 34.7 & $3,600,000$ \\
\hline $75-69-4$ & Freon 11 (Trichlorofluoromethane) & 1.65 & 1.98 & $5,600,000$ \\
\hline $75-71-8$ & Freon 12 (Dichlorodifluoromethane) & 2.96 & 3.8 & $4,950,000$ \\
\hline $75-83-2$ & 2,2-Dimethylbutane (Neohexane) & 0.22 & 4.2 & $1,790,000$ \\
\hline $76-13-1$ & Freon 113 (1,1,2-Trichloro-1,2,2-trifluoroethane) & 0.66 & 1.13 & $7,600,000$ \\
\hline $76-14-2$ & Freon 114 (1,2-Dichlorotetrafluoroethane) & 0.1 & 0.18 & $7,000,000$ \\
\hline $763-29-1$ & 2-Methyl-1-pentene & 0.08 & 0.82 & None \\
\hline $78-78-4$ & 2-Methylbutane (Isopentane) & 9 & 210 & $1,800,000$ \\
\hline $78-79-5$ & Isoprene & 0.2 & 1.0 & 100,000 \\
\hline $78-93-3$ & 2-Butanone (Methyl Ethyl Ketone) & 1.1 & 8.2 & 590,000 \\
\hline $79-29-8$ & 2,3-Dimethylbutane & 0.33 & 6.8 & $1,790,000$ \\
\hline $80-56-8$ & alpha-Pinene & 1 & 9.7 & None \\
\hline $811-97-2$ & Halocarbon 134A & 0.24 & 1.08 & $4,240,000$ \\
\hline $95-47-6$ & o-Xylene & 0.43 & 1.7 & 435,000 \\
\hline $95-63-6$ & 1,2,4-Trimethylbenzene & 0.31 & 1.37 & 125,000 \\
\hline $96-14-0$ & 3-Methylpentane & 0.7 & 14 & $1,790,000$ \\
\hline $96-37-7$ & Methylcyclopentane & 0.4 & 8.2 & None \\
\hline
\end{tabular}

*8-hour time weighted average (TWA)

HAPs are in bold 
Table 9-4. Occupational TWAs for NonRadNET VOCs Detected With $10 \%$ to $50 \%$ Frequency

\begin{tabular}{|c|c|c|c|c|}
\hline CAS & Name & $\begin{array}{c}\text { LANL } \\
\text { Mean } \\
\left(\mu \mathrm{g} / \mathrm{m}^{3}\right)\end{array}$ & $\begin{array}{c}\text { LANL } \\
\text { Max } \\
\left(\mu g / \mathbf{m}^{3}\right)\end{array}$ & $\begin{array}{c}\mathrm{TWA} * \\
\left(\mu \mathrm{g} / \mathbf{m}^{3}\right)\end{array}$ \\
\hline $106-46-7$ & 1,4-Dichlorobenzene (p-Dichlorobenzene) & 0.1 & 0.40 & 458,000 \\
\hline $108-05-4$ & Vinyl Acetate & 1.7 & 4.5 & 35,800 \\
\hline $108-10-1$ & 4-Methyl-2-pentanone (Methyl isobutyl ketone) & 0.27 & 2.4 & 417,000 \\
\hline $108-90-7$ & Chlorobenzene & 0.04 & 0.088 & 350,000 \\
\hline $111-66-0$ & 1-Octene & 0.08 & 0.27 & None \\
\hline $111-71-7$ & Heptanal & 0.95 & 5.7 & None \\
\hline $120-82-1$ & 1,2,4-Trichlorobenzene & 0.22 & 1.18 & 37,000 \\
\hline $124-11-8$ & 1-Nonene & 0.08 & 0.18 & None \\
\hline $127-18-4$ & Tetrachloroethene (Perchloroethylene, Tetrachloroethylene) & 0.13 & 0.56 & 690,000 \\
\hline $127-91-3$ & beta-Pinene & 0.15 & 0.60 & None \\
\hline $138-86-3$ & Limonene & 0.12 & 0.61 & None \\
\hline $142-29-0$ & Cyclopentene & 0.09 & 1.07 & None \\
\hline $3522-94-9$ & 2,2,5-Trimethylhexane & 0.04 & 0.15 & None \\
\hline $496-11-7$ & Indan & 0.04 & 0.13 & None \\
\hline $563-45-1$ & 3-Methyl-1-butene & 0.27 & 2.6 & None \\
\hline $691-38-3$ & cis/trans-4-Methyl-2-pentene & 0.11 & 0.81 & None \\
\hline $693-89-0$ & 1-Methylcyclopentene & 0.11 & 0.84 & None \\
\hline $71-36-3$ & 1-Butanol (n-Butyl Alcohol) & 0.8 & 4.6 & 300,000 \\
\hline $75-00-3$ & Chloroethane (Ethyl Chloride) Freon 160 & 0.12 & 0.28 & $2,600,000$ \\
\hline $75-43-4$ & Freon 21 (Dichlorofluoromethane) & 0.03 & 0.055 & $4,200,000$ \\
\hline $7642-09-3$ & cis-3-Hexene & 0.09 & 0.76 & None \\
\hline $7688-21-3$ & cis-2-Hexene & 0.07 & 0.49 & None \\
\hline $821-95-4$ & 1-Undecene & 0.27 & 0.95 & None \\
\hline $87-68-3$ & Hexachlorobutadiene & 0.35 & 1.6 & 240 \\
\hline $91-20-3$ & Naphthalene & 0.11 & 0.17 & 50,000 \\
\hline $922-62-3$ & cis-3-Methyl-2-pentene & 0.1 & 0.63 & None \\
\hline $99-87-6$ & 4-Isopropyltoluene (p-Cymeme) & 0.08 & 0.18 & 140,000 \\
\hline
\end{tabular}


Table 9-5. Occupational TWAs for NonRadNET VOCs Detected With $<10 \%$ Frequency

\begin{tabular}{|c|c|c|c|c|}
\hline CAS & Name & $\begin{array}{c}\text { LANL } \\
\text { Mean } \\
\left(\mu g / \mathbf{m}^{3}\right)\end{array}$ & $\begin{array}{c}\text { LANL } \\
\text { Max } \\
\left(\mu g / \mathbf{m}^{3}\right)\end{array}$ & $\begin{array}{l}\text { TWA* } \\
\left(\mu \mathrm{g} / \mathbf{m}^{3}\right)\end{array}$ \\
\hline $100-44-7$ & Chlorotoluene (Benzyl Chloride) & ND & $<0.31$ & 5,260 \\
\hline $10061-01-5$ & cis-1,3-Dichloropropene & ND & $<0.19$ & 4,610 \\
\hline $10061-02-6$ & trans-1,3-Dichloropropene & ND & $<0.18$ & 4,610 \\
\hline $104-51-8$ & n-Butylbenzene & 0.05 & 0.17 & None \\
\hline $105-05-5$ & 1,4-Diethylbenzene (p-Diethylbenzene) & 0.04 & 0.089 & None \\
\hline $106-43-4$ & 4-Chlorotoluene & ND & $<1.8$ & None \\
\hline $106-93-4$ & Ethylene Dibromide (1,2-Dibromoethane) & 0.08 & 0.13 & 156,000 \\
\hline $107-06-2$ & 1, 2-Dichloroethane (Ethylene Dichloride) & 0.03 & 0.10 & 206,000 \\
\hline $107-13-1$ & Acrylonitrile & ND & $<0.14$ & 4,400 \\
\hline $107-40-4$ & 2,4,4-Trimethyl-2-pentene & ND & $<0.33$ & None \\
\hline $108-41-8$ & 3-Chlorotoluene (measured as 2- and 3-Chlorotoluene) & ND & $<3.2$ & None \\
\hline $110-83-8$ & Cyclohexene & 0.04 & 0.08 & $1,015,000$ \\
\hline $123-91-1$ & 1,4-Dioxane (1,4-Diethyloxide) & ND & $<0.59$ & 360,000 \\
\hline $124-48-1$ & Dibromochloromethane & ND & $<0.56$ & None \\
\hline $126-99-8$ & 2-Chloro-1,3-butadiene (Chloroprene) & ND & $<0.14$ & 90,000 \\
\hline $141-32-2$ & Butyl Acrylate & ND & $<1.23$ & 11,000 \\
\hline $141-93-5$ & 1,3-Diethylbenzene (m-Diethylbenzene) & 0.03 & 0.077 & None \\
\hline $14686-13-6$ & trans-2-Heptene & 0.07 & 0.14 & None \\
\hline 14686-14-7 & trans-3-Heptene & 0.15 & 0.43 & None \\
\hline $156-59-2$ & cis-1,2 Dichloroethene & ND & $<0.17$ & 806,000 \\
\hline $156-60-5$ & trans-1,2-Dichloroethene & ND & $<0.15$ & 806,000 \\
\hline $1634-04-4$ & Methyl tert-Butyl Ether & 0.05 & 0.16 & 146,000 \\
\hline $2198-23-4$ & 4-Nonene & ND & $<0.32$ & None \\
\hline $538-93-2$ & Isobutylbenzene & ND & $<1.9$ & 558,000 \\
\hline $541-73-1$ & 1,3-Dichlorobenzene & 0.14 & 0.30 & None \\
\hline $591-49-1$ & 1-Methylcyclohexene & ND & $<0.28$ & None \\
\hline 593-60-2 & Vinyl bromide & ND & $<0.41$ & 2,000 \\
\hline
\end{tabular}


Table 9-5 (cont.)

\begin{tabular}{|c|c|c|c|c|}
\hline CAS & Name & $\begin{array}{c}\text { LANL } \\
\text { Mean } \\
\left(\mu g / \mathbf{m}^{3}\right)\end{array}$ & $\begin{array}{c}\text { LANL } \\
\operatorname{Max} \\
\left(\mu \mathrm{g} / \mathrm{m}^{3}\right)\end{array}$ & $\begin{array}{c}\text { TWA }^{*} \\
\left(\mu \mathrm{g} / \mathrm{m}^{3}\right)\end{array}$ \\
\hline $691-37-2$ & 4-Methyl-1-pentene & 0.17 & 0.52 & None \\
\hline $71-23-8$ & 1-Propanol & 1.5 & 2.7 & 500,000 \\
\hline $74-97-5$ & Bromochloromethane & ND & $<0.11$ & $1,050,000$ \\
\hline $75-01-4$ & Vinyl Chloride & 0.08 & 0.083 & 2,600 \\
\hline $75-25-2$ & Bromoform & ND & $<0.89$ & 5,000 \\
\hline $75-27-4$ & Bromodichloromethane & ND & $<0.39$ & None \\
\hline $75-34-3$ & 1,1-Dichloroethane (Ethylidene Dichloride) & ND & $<0.08$ & 400,000 \\
\hline $75-35-4$ & 1,1-Dichloroethene (Vinylidene Chloride) & ND & $<0.09$ & 4,000 \\
\hline $760-21-4$ & 2-Ethyl-1-butene & 0.09 & 0.17 & None \\
\hline $7642-04-8$ & cis-2-Octene & ND & $<0.3$ & None \\
\hline $7642-10-6$ & cis-3-Heptene & 0.19 & 0.62 & None \\
\hline $78-87-5$ & 1,2-Dichloropropane (Propylene Dichloride) & ND & $<0.11$ & 350,000 \\
\hline $79-00-5$ & 1,1,2-Trichloroethane & ND & $<0.12$ & 45,000 \\
\hline $79-01-6$ & Trichloroethene (Trichloroethylene) & 0.08 & 0.23 & 546,000 \\
\hline $79-34-5$ & 1,1,2,2-Tetrachloroethane & 0.08 & 0.15 & 35,000 \\
\hline $872-05-9$ & 1-Decene & ND & $<1.9$ & None \\
\hline $95-13-6$ & Indene & 0.02 & 0.047 & 48,000 \\
\hline $95-49-8$ & 2-Chlorotoluene (measured as 2- and 3-Chlorotoluene) & ND & $<3.2$ & 250,000 \\
\hline $95-50-1$ & 1,2-Dichlorobenzene & 0.17 & 0.35 & 300,000 \\
\hline $98-06-6$ & tert-Butylbenzene & ND & $<2.2$ & None \\
\hline $98-82-8$ & Isopropylbenzene (Cumene) & 0.04 & 0.07 & 245,000 \\
\hline
\end{tabular}

*8-hour time weighted average (TWA)

HAPs are in bold 


\subsection{Conclusion}

The purpose of this paper was to organize and describe the NonRadNET data collected over 2001-2002 for future use as baseline data, either for monitoring during a fire, some other abnormal event, or routine use. To achieve that purpose, in this paper we

- documented the NonRadNET program procedures, methods, and quality management,

- described the usual origins and uses of the species measured,

- compared the species measured to LANL and other area emissions,

- presented the data,

- compared the data to typical environmental values, and

- evaluated the data against exposure standards.

The airborne particle (TSP, $\mathrm{PM}_{10}$, and $\mathrm{PM}_{2.5}$ ) concentrations measured were well within normal ranges. Furthermore, when compared to vehicle, natural, and other particulate emission sources, LANL does not significantly affect the particulate concentration in the ambient atmosphere, except perhaps in the immediate vicinity of air curtain destructors used to dispose of large quantities of waste wood generated by the Cerro Grande fire recovery effort.

Of the 20 inorganic elements measured, most were very low compared to national values. Our measurements for barium, beryllium, iron, and vanadium may be slightly higher than typical national values.

For the 160 VOCs measured, we generally observed that the results were low to much lower than typical national concentrations. However, we observed that the concentrations for benzaldehyde, butyraldehyde, acetone, and acetaldehyde appear to be higher than the few national values we found for comparison with them. We did conservatively conclude that LANL may contribute measurably to the airborne concentrations of 2, 4, 4-trimethyl-1-pentene and Freon 22 (chlorodifluoromethane).

Based on our measurements, the ambient air concentrations around LANL tend to be significantly lower than in major urban areas, roughly typical of rural areas, and are many orders of magnitude below regulatory standards considered safe for occupational exposure (since environmental exposure standards do not exist for most of these species).

\section{Acknowledgments}

The authors wish to acknowledge Gary Hall with URS for his extensive efforts to successfully install, operate, and maintain the air sampling equipment. The consistent, high-quality field work by Alice Baumann and Jake Martinez of the University of California-Los Alamos National Laboratory was essential for the sample collection activities. We also wish to acknowledge Angelique Luedeker of Northern Arizona University for her tireless efforts in analytical data quality review. Her attention to detail and thorough quality assurance review of all laboratory data were instrumental to the quality of the data generated from this program. 


\section{References}

[ATSDR-PHSB] Agency for Toxic Substances and Disease Registry, "Public Health Statement for Benzene" [Online], www.atsdr.cdc.gov/toxprofiles/phs3.html (September 1997).

[ATSDR-TPIS] Agency for Toxic Substances and Disease Registry, "Toxicological Profile Information Sheet" [Online], www.atsdr.cdc.gov/ToxProfiles.

[CARB] California Air Resources Board, "Compound Summaries" [Online]. www.arb.ca.gov/toxics/tac/toctbl.htm.

[EPA] Environmental Protection Agency, "National Primary and Secondary Ambient Air Quality Standards," Code of Federal Regulations, Title 40 Parts 50.6 and 50.7.

[EPA1999] Environmental Protection Agency, “Ambient Air Quality Surveillance," Code of Federal Regulations, Title 40 Part 58 (July 1, 1999).

[EPA2000] Environmental Protection Agency, "Draft Technical Support Document: Control of Emissions of Hazardous Air Pollutants from Motor Vehicles and Motor Vehicle Fuels," EPA420-D-00003, www.epa.gov/otaq/regs/toxics/d00003.pdf (July 2000).

[EPA2001] Environmental Protection Agency, "1999/2000r Toxics Monitoring Program (UATMP)," EPA 454/R-02-009, http://www.epa.gov/ttn/amtic/files/ambient/airtox/9900uat.pdf (March 2001).

[EPA-ATPM] Environmental Protection Agency, Air Trends (Particulate Matter) web site, http://www.epa.gov/airtrends/pm.html.

[EPA-ATPMMD] Environmental Protection Agency, Air Trends (More Details on Particulate Matter) web site, http://www.epa.gov/airtrends/pm2.html.

[EPA-HAP] Environmental Protection Agency, "Original List of Hazardous Air Pollutants" [Online], www.epa.gov/ttn/atw/188polls.html.

[EPA-HENHAP] Environmental Protection Agency, "Health Effects Notebook for Hazardous Air Pollutants" [Online], www.epa.gov/ttn/atw/hapindex.html.

[EPA-NATA] Environmental Protection Agency, "National-Scale Air Toxics Assessment Overview: The 33 Pollutants" [Online], www.epa.gov/ttn/atw/nata/34poll.html.

[EPA-PAMS] Environmental Protection Agency, "PAMS General Information, Target Parameters" [Online], www.epa.gov/oar/oaqps/pams/general.html\#parameters.

[EPA-PM] Environmental Protection Agency, "Particulate Matter (Pm)" [Online], www.epa.gov/ebtpages/airairpolparticulatematterpm.html.

[EPA-TRI] Environmental Protection Agency, "2000 Toxics Release Inventory (TRI) State Fact Sheets" [Online], www.epa.gov/triinter/tridata/tri00/state/index.htm.

[EPA-TVPIS] Environmental Protection Agency, “Title V Permit Issuance Statistics" [Online], www.epa.gov/air/oaqps/permits/maps/permtblsm.html. 
[Gladney2001] E. S. Gladney and A. Luedeker, "Final Report, LANL ESH-17 Assessment of the Radiochemistry Facilities at Wastren, Inc., Grand Junction, CO, September 10 - 12, 2001," ESH-17:01542, letter to Ron Chessmore, Wastren Analytical Laboratory (December 19, 2001).

[Gladney2003] E. S. Gladney and T. L. Morgan, "LANL MAQ Assessment of the Inorganic and Radiochemistry Facilities at the DOE Grand Junction Office Analytical Laboratory, CO, October 2002," MAQ:03-168, letter to Ron Chessmore, Stoller - Grand Junction Analytical Laboratory (July 2003).

[IPCS] International Programme on Chemical Safety, "INCHEM Chemical Information (CIS)" [Online], www.inchem.org/pages/ilodb.html.

[LANL2000] Los Alamos National Laboratory, "Evaluation of AIRNET Sampler Sites Against Siting Criteria," RRES-MAQ-207, R1 (February 22, 2000).

[LANL2001] Los Alamos National Laboratory, "2001 Toxic Chemicals Release Inventory Report for the Emergency Planning and Community Right-to-Know Act of 1986, Title III, Section 313,” LA-14071-PR (September 2003).

[LANL2002] Los Alamos National Laboratory, "Environmental Surveillance at Los Alamos during 2001,” LA-13979-ENV (September 2002).

[LANL2002a] Los Alamos National Laboratory, "Quality Assurance Project Plan for the NonRadiological Air Sampling Network (NonRadNET)”, RRES MAQ-NonRadNET, R0 (September 19, 2002).

[LANL2002b] Los Alamos National Laboratory, "2002 Toxic Chemicals Release Inventory Report for the Emergency Planning and Community Right-to-Know Act of 1986, Title III, Section 313," LA-14096PR (November 2003).

[LANL2003] Los Alamo National Laboratory, "Environmental Surveillance at Los Alamos during 2002," Draft (2003).

[LANL2003a] Los Alamos National Laboratory, "Emissions Inventory Report Summary: Reporting Requirements for the New Mexico Administrative Code, Title 20, Chapter 2, Part 73 (20.2.73 NMAC) for Calendar Year 2001,” LA-13990-SR (January 2003).

[LANL2003b] Los Alamos National Laboratory, "Emissions Inventory Report Summary: Reporting Requirements for the New Mexico Administrative Code, Title 20, Chapter 2, Part 73 (20.2.73 NMAC) for Calendar Year 2002,” LA-14089-SR (November 2003).

[Morgan] T. Morgan, P. Beaulieu and T. Stirrup, "Final Report, LANL ESH-17 Assessment of STLAustin Quality Program, December 11-12, 2001," ESH-17:02-093, Letter to Linda Voigt, STL-Austin (March 6, 2002).

[OSHA1910] Occupational Safety and Health Administration, "Occupational Safety and Health Standards,” Air Contaminants, Code of Federal Regulations, Title 29 Part 1910.1000.

[Winter] Dr Mark J. Winter, "Web Elements Periodic Table” [Online], http://www.webelements.com. 


\section{APPENDIX A \\ Comprehensive NonRadNET VOC Data}

This appendix contains a listing of the 160 volatile organic compounds (VOCs) monitored as part of NonRadNET. Two comprehensive lists of the monitored VOCs, one ordered by Chemical Abstract Service (CAS) number and one ordered alphabetically, are provided.

NonRadNET Volatile Organic Compounds Ordered By CAS Number

$\begin{aligned} \text { CAS \# } & \\ 100-41-4 & \text { Ethyl Benzene } \\ 100-42-5 & \text { Styrene } \\ 100-44-7 & \text { Chlorotoluene (Benzyl Chloride) } \\ 100-52-7 & \text { Benzaldehyde } \\ 10061-01-5 & \text { cis-1,3-Dichloropropene } \\ 10061-02-6 & \text { trans-1,3-Dichloropropene } \\ 103-65-1 & \text { n-Propylbenzene } \\ 104-51-8 & \text { n-Butylbenzene } \\ 105-05-5 & \text { 1,4-Diethylbenzene (p-Diethylbenzene) } \\ 106-42-3 & \text { p-Xylene } \\ 106-43-4 & \text { 4-Chlorotoluene } \\ 106-46-7 & \text { 1,4-Dichlorobenzene } \\ 106-93-4 & \text { Ethylene Dibromide (1,2-Dibromoethane) } \\ 106-97-8 & \text { Butane } \\ 106-98-9 & \text { 1-Butene } \\ 106-99-0 & \text { 1,3-Butadiene } \\ 107-06-2 & \text { 1,2-Dichloroethane (Ethylene Dichloride) } \\ 107-13-1 & \text { Acrylonitrile } \\ 107-39-1 & \text { 2,4,4-Trimethyl-1-pentene } \\ 107-40-4 & \text { 2,4,4-Trimethyl-2-pentene } \\ 107-83-5 & \text { Isohexane (2-Methylpentane) } \\ 108-05-4 & \text { Vinyl Acetate } \\ 108-08-7 & \text { 2,4-Dimethylpentane } \\ 108-10-1 & \text { 4-Methyl-2-pentanone (Methyl isobutyl ketone) } \\ 108-38-3 & \text { m-Xylene } \\ 108-41-8 & \text { 3-Chlorotoluene } \\ 108-67-8 & \text { 1,3,5-Trimethylbenzene } \\ 108-87-2 & \text { Methylcyclohexane } \\ 108-88-3 & \text { Toluene } \\ 108-90-7 & \text { Chlorobenzene } \\ 109-66-0 & \text { Pentane } \\ 109-67-1 & \text { 1-Pentene } \\ 110-54-3 & \text { Hexane } \\ 110-82-7 & \text { Cyclohexane } \\ 110-83-8 & \text { Cyclohexene } \\ 111-65-9 & \text { n-Octane } \\ 111-66-0 & \text { 1-Octene } \\ & \end{aligned}$




\begin{tabular}{|c|c|}
\hline CAS \# & Name \\
\hline $111-71-7$ & Heptanal \\
\hline $111-84-2$ & n-Nonane \\
\hline $1120-21-4$ & n-Undecane \\
\hline $115-07-1$ & Propylene \\
\hline $120-82-1$ & 1,2,4-Trichlorobenzene \\
\hline $123-72-8$ & Butyraldehyde \\
\hline $123-91-1$ & 1,4-Dioxane (1,4-Diethyloxide) \\
\hline $124-11-8$ & 1-Nonene \\
\hline $124-18-5$ & n-Decane \\
\hline $124-48-1$ & Dibromochloromethane \\
\hline $126-99-8$ & 2-Chloro-1,3-butadiene (Chloroprene) \\
\hline $127-18-4$ & Tetrachloroethene (Perchloroethylene, Tetrachloroethylene) \\
\hline $127-91-3$ & beta-Pinene \\
\hline $1330-20-7$ & mixed Xylenes \\
\hline $138-86-3$ & Limonene \\
\hline $141-32-2$ & Butyl Acrylate \\
\hline $141-93-5$ & 1,3-Diethylbenzene (m-Diethylbenzene) \\
\hline $142-29-0$ & Cyclopentene \\
\hline $142-82-5$ & Heptane \\
\hline $14686-13-6$ & trans-2-Heptene \\
\hline $14686-14-7$ & trans-3-Heptene \\
\hline $156-59-2$ & cis-1,2 Dichloroethene \\
\hline $156-60-5$ & trans-1,2-Dichloroethene \\
\hline 1634-04-4 & Methyl tert-Butyl Ether \\
\hline $2198-23-4$ & 4-Nonene \\
\hline $287-92-3$ & Cyclopentane \\
\hline $31394-54-4$ & Isoheptane (2-Methylhexane) \\
\hline $3522-94-9$ & $2,2,5$-Trimethylhexane \\
\hline $4050-45-7$ & trans-2-Hexene \\
\hline $463-82-1$ & Neopentane \\
\hline $496-11-7$ & Indan \\
\hline $513-35-9$ & 2-Methyl-2-butene \\
\hline $526-73-8$ & 1,2,3-Trimethylbenzene \\
\hline $538-93-2$ & Isobutylbenzene \\
\hline $540-84-1$ & 2,2,4-Trimethylpentane (Isooctane) \\
\hline $541-73-1$ & 1,3-Dichlorobenzene \\
\hline $56-23-5$ & Carbon Tetrachloride \\
\hline $563-45-1$ & 3-Methyl-1-butene \\
\hline $564-02-3$ & 2,2,3-Trimethylpentane \\
\hline $565-59-3$ & 2,3-Dimethylpentane \\
\hline $565-75-3$ & 2,3,4-Trimethylpentane \\
\hline $589-34-4$ & 3-Methylhexane \\
\hline $589-81-1$ & 3-Methylheptane \\
\hline $590-18-1$ & cis-2-Butene \\
\hline $591-49-1$ & 1-Methylcyclohexene \\
\hline
\end{tabular}




\begin{tabular}{|c|c|}
\hline CAS \# & Name \\
\hline $592-13-2$ & 2,5-Dimethylhexane \\
\hline $592-27-8$ & 2-Methylheptane \\
\hline $592-41-6$ & 1-Hexene \\
\hline $592-76-7$ & 1-Heptene \\
\hline $593-60-2$ & Vinyl bromide \\
\hline $60-29-7$ & Diethyl ether \\
\hline $611-14-3$ & 2-Ethyltoluene (o-Ethyltoluene) \\
\hline $620-14-4$ & 3-Ethyltoluene (m-Ethyltoluene) \\
\hline $622-96-8$ & 4-Ethyltoluene ( $\mathrm{p}$-Ethyltoluene) \\
\hline $624-64-6$ & trans-2-Butene \\
\hline $625-27-4$ & 2-Methyl-2-pentene \\
\hline $627-20-3$ & cis-2-Pentene \\
\hline $64-17-5$ & Ethanol (Ethyl alcohol) \\
\hline $646-04-8$ & trans-2-Pentene \\
\hline $66-25-1$ & Hexanal \\
\hline $67-56-1$ & Methanol (Methyl alcohol) \\
\hline $67-63-0$ & 2-Propanol (Isopropyl Alcohol) \\
\hline $67-64-1$ & Acetone (2-Propanone) \\
\hline $67-66-3$ & Chloroform \\
\hline $691-37-2$ & 4-Methyl-1-pentene \\
\hline $691-38-3$ & cis/trans-4-Methyl-2-pentene \\
\hline $693-89-0$ & 1-Methylcyclopentene \\
\hline $71-23-8$ & 1-Propanol \\
\hline $71-36-3$ & 1-Butanol (n-Butyl Alcohol) \\
\hline $71-43-2$ & Benzene \\
\hline $71-55-6$ & 1,1,1-Trichloroethane (Methyl Chloroform) \\
\hline $74-83-9$ & Bromomethane (Methyl Bromide) \\
\hline $74-84-0$ & Ethane \\
\hline $74-85-1$ & Ethylene \\
\hline $74-86-2$ & Acetylene \\
\hline $74-87-3$ & Freon 40 Chloromethane (Methyl Chloride) \\
\hline $74-97-5$ & Bromochloromethane \\
\hline $74-98-6$ & Propane \\
\hline $75-00-3$ & Chloroethane (Ethyl Chloride) Freon 160 \\
\hline $75-01-4$ & Vinyl Chloride \\
\hline $75-05-8$ & Acetonitrile \\
\hline $75-07-0$ & Acetaldehyde \\
\hline $75-09-2$ & Methylene Chloride (Dichloromethane) \\
\hline $75-25-2$ & Bromoform \\
\hline $75-27-4$ & Bromodichloromethane \\
\hline $75-28-5$ & Isobutane \\
\hline $75-34-3$ & 1,1-Dichloroethane (Ethylidene Dichloride) \\
\hline $75-35-4$ & 1,1-Dichloroethene (Vinylidene Chloride) \\
\hline $75-43-4$ & Freon 21 (Dichlorofluoromethane) \\
\hline $75-45-6$ & Freon 22 (Chlorodifluoromethane) \\
\hline
\end{tabular}




\begin{tabular}{|c|c|}
\hline $\begin{array}{l}\text { CAS \# } \\
75-69-4\end{array}$ & $\begin{array}{c}\text { Name } \\
\text { Freon } 11 \text { (Trichlorofluoromethane) }\end{array}$ \\
\hline $75-71-8$ & Freon 12 (Dichlorodifluoromethane) \\
\hline $75-83-2$ & 2,2-Dimethylbutane (Neohexane) \\
\hline $760-21-4$ & 2-Ethyl-1-butene \\
\hline $76-13-1$ & Freon 113 (1,1,2-Trichloro-1,2,2-trifluoroethane) \\
\hline $76-14-2$ & Freon 114 (1,2-Dichlorotetrafluoroethane) \\
\hline $763-29-1$ & 2-Methyl-1-pentene \\
\hline $7642-04-8$ & cis-2-Octene \\
\hline $7642-09-3$ & cis-3-Hexene \\
\hline $7642-10-6$ & cis-3-Heptene \\
\hline $7688-21-3$ & cis-2-Hexene \\
\hline $78-78-4$ & 2-Methylbutane (Isopentane) \\
\hline $78-79-5$ & Isoprene \\
\hline $78-87-5$ & 1,2-Dichloropropane (Propylene Dichloride) \\
\hline $78-93-3$ & 2-Butanone (Methyl Ethyl Ketone) \\
\hline $79-00-5$ & 1,1,2-Trichloroethane \\
\hline $79-01-6$ & Trichloroethene (Trichloroethylene) \\
\hline $79-29-8$ & 2,3-Dimethylbutane \\
\hline $79-34-5$ & 1,1,2,2-Tetrachloroethane \\
\hline $80-56-8$ & alpha-Pinene \\
\hline $811-97-2$ & Halocarbon 134A \\
\hline $821-95-4$ & 1-Undecene \\
\hline $872-05-9$ & 1-Decene \\
\hline $87-68-3$ & Hexachlorobutadiene \\
\hline $91-20-3$ & Naphthalene \\
\hline $922-62-3$ & cis-3-Methyl-2-pentene \\
\hline $95-13-6$ & Indene \\
\hline $95-47-6$ & o-Xylene \\
\hline $95-49-8$ & 2-Chlorotoluene \\
\hline $95-50-1$ & 1,2-Dichlorobenzene \\
\hline $95-63-6$ & 1,2,4-Trimethylbenzene \\
\hline $96-14-0$ & 3-Methylpentane \\
\hline $96-37-7$ & Methylcyclopentane \\
\hline $98-06-6$ & tert-Butylbenzene \\
\hline $98-82-8$ & Isopropylbenzene (Cumene) \\
\hline $99-87-6$ & 4-Isopropyltoluene (p-Cymeme) \\
\hline
\end{tabular}


NonRadNET Volatile Organic Compounds Ordered Alphabetically

\begin{tabular}{ll}
\multicolumn{1}{c}{ CAS \# } & \multicolumn{1}{c}{ Name } \\
$107-06-2$ & 1, 2-Dichloroethane (Ethylene Dichloride) \\
$71-55-6$ & 1,1,1-Trichloroethane (Methyl Chloroform) \\
$79-34-5$ & 1,1,2,2-Tetrachloroethane \\
$79-00-5$ & 1,1,2-Trichloroethane \\
$75-34-3$ & 1,1-Dichloroethane (Ethylidene Dichloride) \\
$75-35-4$ & 1,1-Dichloroethene (Vinylidene Chloride) \\
$526-73-8$ & 1,2,3-Trimethylbenzene \\
$120-82-1$ & 1,2,4-Trichlorobenzene \\
$95-63-6$ & 1,2,4-Trimethylbenzene \\
$95-50-1$ & 1,2-Dichlorobenzene \\
$78-87-5$ & 1,2-Dichloropropane (Propylene Dichloride) \\
$108-67-8$ & 1,3,5-Trimethylbenzene \\
$106-99-0$ & 1,3-Butadiene \\
$541-73-1$ & 1,3-Dichlorobenzene \\
$141-93-5$ & 1,3-Diethylbenzene (m-Diethylbenzene) \\
$106-46-7$ & 1,4-Dichlorobenzene \\
$105-05-5$ & 1,4-Diethylbenzene (p-Diethylbenzene) \\
$123-91-1$ & 1,4-Dioxane (1,4-Diethyloxide) \\
$71-36-3$ & 1-Butanol (n-Butyl Alcohol) \\
$106-98-9$ & 1-Butene \\
$872-05-9$ & 1-Decene \\
$592-76-7$ & 1-Heptene \\
$592-41-6$ & 1-Hexene \\
$591-49-1$ & 1-Methylcyclohexene \\
$693-89-0$ & 1-Methylcyclopentene \\
$124-11-8$ & 1-Nonene \\
$111-66-0$ & 1-Octene \\
$109-67-1$ & 1-Pentene \\
$71-23-8$ & 1-Propanol \\
$821-95-4$ & 1-Undecene \\
$564-02-3$ & 2,2,3-Trimethylpentane \\
$540-84-1$ & 2,2,4-Trimethylpentane (Isooctane) \\
$3522-94-9$ & 2,2,5-Trimethylhexane \\
$75-83-2$ & 2,2-Dimethylbutane (Neohexane) \\
$565-75-3$ & 2,3,4-Trimethylpentane \\
$79-29-8$ & 2,3-Dimethylbutane \\
$565-59-3$ & 2,3-Dimethylpentane \\
$107-39-1$ & 2,4,4-Trimethyl-1-pentene \\
$107-40-4$ & 2,4,4-Trimethyl-2-pentene \\
108-08-7 & 2,4-Dimethylpentane \\
2,-13-2 & 2-But-Dimethylhexane \\
2-Chloro-1,3-butadiene (Chloroprene)
\end{tabular}




\begin{tabular}{|c|c|}
\hline CAS \# & Name \\
\hline $95-49-8$ & 2-Chlorotoluene \\
\hline $760-21-4$ & 2-Ethyl-1-butene \\
\hline $611-14-3$ & 2-Ethyltoluene (o-Ethyltoluene) \\
\hline $763-29-1$ & 2-Methyl-1-pentene \\
\hline $513-35-9$ & 2-Methyl-2-butene \\
\hline $625-27-4$ & 2-Methyl-2-pentene \\
\hline $78-78-4$ & 2-Methylbutane (Isopentane) \\
\hline $592-27-8$ & 2-Methylheptane \\
\hline $67-63-0$ & 2-Propanol (Isopropyl Alcohol) \\
\hline $108-41-8$ & 3-Chlorotoluene \\
\hline $620-14-4$ & 3-Ethyltoluene (m-Ethyltoluene) \\
\hline $563-45-1$ & 3-Methyl-1-butene \\
\hline $589-81-1$ & 3-Methylheptane \\
\hline $589-34-4$ & 3-Methylhexane \\
\hline $96-14-0$ & 3-Methylpentane \\
\hline $106-43-4$ & 4-Chlorotoluene \\
\hline $622-96-8$ & 4-Ethyltoluene (p-Ethyltoluene) \\
\hline $99-87-6$ & 4-Isopropyltoluene (p-Cymeme) \\
\hline $691-37-2$ & 4-Methyl-1-pentene \\
\hline $108-10-1$ & 4-Methyl-2-pentanone (Methyl isobutyl ketone) \\
\hline $2198-23-4$ & 4-Nonene \\
\hline $75-07-0$ & Acetaldehyde \\
\hline $67-64-1$ & Acetone (2-Propanone) \\
\hline $75-05-8$ & Acetonitrile \\
\hline $74-86-2$ & Acetylene \\
\hline $107-13-1$ & Acrylonitrile \\
\hline $80-56-8$ & alpha-Pinene \\
\hline $100-52-7$ & Benzaldehyde \\
\hline $71-43-2$ & Benzene \\
\hline $127-91-3$ & beta-Pinene \\
\hline $74-97-5$ & Bromochloromethane \\
\hline $75-27-4$ & Bromodichloromethane \\
\hline $75-25-2$ & Bromoform \\
\hline $74-83-9$ & Bromomethane (Methyl Bromide) \\
\hline $106-97-8$ & Butane \\
\hline $141-32-2$ & Butyl Acrylate \\
\hline $123-72-8$ & Butyraldehyde \\
\hline $56-23-5$ & Carbon Tetrachloride \\
\hline $108-90-7$ & Chlorobenzene \\
\hline $75-00-3$ & Chloroethane (Ethyl Chloride) Freon 160 \\
\hline $67-66-3$ & Chloroform \\
\hline $100-44-7$ & Chlorotoluene (Benzyl Chloride) \\
\hline $691-38-3$ & cis/trans-4-Methyl-2-pentene \\
\hline $156-59-2$ & cis-1,2 Dichloroethene \\
\hline $10061-01-5$ & cis-1,3-Dichloropropene \\
\hline $590-18-1$ & cis-2-Butene \\
\hline
\end{tabular}




\begin{tabular}{|c|c|}
\hline CAS \# & Name \\
\hline $7688-21-3$ & cis-2-Hexene \\
\hline $7642-04-8$ & cis-2-Octene \\
\hline $627-20-3$ & cis-2-Pentene \\
\hline $7642-10-6$ & cis-3-Heptene \\
\hline $7642-09-3$ & cis-3-Hexene \\
\hline $922-62-3$ & cis-3-Methyl-2-pentene \\
\hline $110-82-7$ & Cyclohexane \\
\hline $110-83-8$ & Cyclohexene \\
\hline $287-92-3$ & Cyclopentane \\
\hline $142-29-0$ & Cyclopentene \\
\hline $124-48-1$ & Dibromochloromethane \\
\hline $60-29-7$ & Diethyl ether \\
\hline $74-84-0$ & Ethane \\
\hline $64-17-5$ & Ethanol (Ethyl alcohol) \\
\hline $100-41-4$ & Ethyl Benzene \\
\hline $74-85-1$ & Ethylene \\
\hline $106-93-4$ & Ethylene Dibromide (1,2-Dibromoethane) \\
\hline $75-69-4$ & Freon 11 (Trichlorofluoromethane) \\
\hline $76-13-1$ & Freon 113 (1,1,2-Trichloro-1,2,2-trifluoroethane) \\
\hline $76-14-2$ & Freon 114 (1,2-Dichlorotetrafluoroethane) \\
\hline $75-71-8$ & Freon 12 (Dichlorodifluoromethane) \\
\hline $75-43-4$ & Freon 21 (Dichlorofluoromethane) \\
\hline $75-45-6$ & Freon 22 (Chlorodifluoromethane) \\
\hline $74-87-3$ & Freon 40 Chloromethane (Methyl Chloride) \\
\hline $811-97-2$ & Halocarbon 134A \\
\hline $111-71-7$ & Heptanal \\
\hline $142-82-5$ & Heptane \\
\hline $87-68-3$ & Hexachlorobutadiene \\
\hline $66-25-1$ & Hexanal \\
\hline $110-54-3$ & Hexane \\
\hline $496-11-7$ & Indan \\
\hline $95-13-6$ & Indene \\
\hline $75-28-5$ & Isobutane \\
\hline $538-93-2$ & Isobutylbenzene \\
\hline $31394-54-4$ & Isoheptane (2-Methylhexane) \\
\hline $107-83-5$ & Isohexane (2-Methylpentane) \\
\hline $78-79-5$ & Isoprene \\
\hline $98-82-8$ & Isopropylbenzene (Cumene) \\
\hline $138-86-3$ & Limonene \\
\hline $67-56-1$ & Methanol (Methyl alcohol) \\
\hline $1634-04-4$ & Methyl tert-Butyl Ether \\
\hline $108-87-2$ & Methylcyclohexane \\
\hline $96-37-7$ & Methylcyclopentane \\
\hline $75-09-2$ & Methylene Chloride (Dichloromethane) \\
\hline $108-38-3$ & $\mathrm{~m}$-Xylene \\
\hline $1330-20-7$ & mixed Xylenes \\
\hline
\end{tabular}




\begin{tabular}{ll}
\multicolumn{1}{c}{ CAS \# } & \multicolumn{1}{c}{ Name } \\
$91-20-3$ & Naphthalene \\
$104-51-8$ & n-Butylbenzene \\
$124-18-5$ & n-Decane \\
$463-82-1$ & Neopentane \\
$111-84-2$ & n-Nonane \\
$111-65-9$ & n-Octane \\
$103-65-1$ & n-Propylbenzene \\
$1120-21-4$ & n-Undecane \\
$95-47-6$ & o-Xylene \\
$109-66-0$ & Pentane \\
$74-98-6$ & Propane \\
$115-07-1$ & Propylene \\
$106-42-3$ & p-Xylene \\
$100-42-5$ & Styrene \\
$98-06-6$ & tert-Butylbenzene \\
$127-18-4$ & Tetrachloroethene (Perchloroethylene, Tetrachloroethylene) \\
$108-88-3$ & Toluene \\
$156-60-5$ & trans-1,2-Dichloroethene \\
$10061-02-6$ & trans-1,3-Dichloropropene \\
$624-64-6$ & trans-2-Butene \\
$14686-13-6$ & trans-2-Heptene \\
$4050-45-7$ & trans-2-Hexene \\
$646-04-8$ & trans-2-Pentene \\
$14686-14-7$ & trans-3-Heptene \\
$79-01-6$ & Trichloroethene (Trichloroethylene) \\
$108-05-4$ & Vinyl Acetate \\
$593-60-2$ & Vinyl bromide \\
$75-01-4$ & Vinyl Chloride \\
& Xylene- see mixed, m-. o-, or p-Xylene \\
&
\end{tabular}




\section{APPENDIX B Special Calculations}

This appendix contains several calculations to support statements made in the body of this paper. The special calculations include

- Converson Factors for Parts Per Billion by Volume (ppbv) to $\mu \mathrm{g} / \mathrm{m}^{3}$

- Estimate of Particulate Emissions from On-Road Vehicles in the Los Alamos Area

- Estimate of Particulate Emissions from Fireplaces in the Los Alamos Area

- Estimate of VOC Emissions from On-Road Vehicles in the Los Alamos Area

- Estimate of VOC Emissions from Fireplaces in the Los Alamos Area

\section{Converson Factors for Parts Per Billion by Volume (ppbv) to $\mu \mathrm{g} / \mathrm{m}^{3}$}

The VOC results published in the 2001 and 2002 Environmental Surveillance Reports are in units of parts per billion by volume (ppbv). The VOC units in this paper are in $\mu \mathrm{g} / \mathrm{m}^{3}$. To convert from ppbv to $\mu \mathrm{g} / \mathrm{m}^{3}$, use the conversion factors below. For example, if you have $2 \mathrm{ppbv}$ of ethyl benzene, multiply it by 4.42 to get $8.84 \mu \mathrm{g} / \mathrm{m}^{3}$. To convert $\mu \mathrm{g} / \mathrm{m}^{3}$ to ppbv, divide ppbv by the factor.

\begin{tabular}{|l|l|c|}
\hline \multicolumn{1}{|c|}{ CAS \# } & \multicolumn{1}{|c|}{ Name } & ppbv to $\mathbf{~ g g} / \mathbf{m}^{3}$ \\
\hline $100-41-4$ & Ethyl Benzene & 4.42 \\
\hline $100-42-5$ & Styrene & 4.33 \\
\hline $100-44-7$ & Chlorotoluene (Benzyl Chloride) & 5.26 \\
\hline $100-52-7$ & Benzaldehyde & 4.41 \\
\hline $10061-01-5$ & cis-1,3-Dichloropropene & 4.61 \\
\hline $10061-02-6$ & trans-1,3-Dichloropropene & 4.61 \\
\hline $103-65-1$ & n-Propylbenzene & 5 \\
\hline $104-51-8$ & n-Butylbenzene & 5.58 \\
\hline $105-05-5$ & $1,4-$ Diethylbenzene (p-Diethylbenzene) & 5.58 \\
\hline $106-42-3$ & p-Xylene (including 108-38-3 m-Xylene) & 4.42 \\
\hline $106-43-4$ & $4-$-Chlorotoluene & 5.26 \\
\hline $106-46-7$ & $1,4-$ Dichlorobenzene & 6.11 \\
\hline $106-93-4$ & Ethylene Dibromide (1,2-Dibromoethane) & 7.81 \\
\hline $106-97-8$ & Butane & 2.42 \\
\hline $106-98-9$ & 1 -Butene & 2.33 \\
\hline $106-99-0$ & 1,3 -Butadiene & 2.25 \\
\hline $107-06-2$ & $1,2-$-Dichloroethane (Ethylene Dichloride) & 4.12 \\
\hline $107-13-1$ & Acrylonitrile & 2.21 \\
\hline $107-39-1$ & $2,4,4-$ Trimethyl-1-pentene & 4.66 \\
\hline $107-40-4$ & $2,4,4-$ Trimethyl-2-pentene & 4.66 \\
\hline $107-83-5$ & Isohexane (2-Methylpentane) & 3.58 \\
\hline $108-05-4$ & Vinyl Acetate & 3.58 \\
\hline $108-08-7$ & $2,4-$ Dimethylpentane & 4.17 \\
\hline $108-10-1$ & $4-$ Methyl-2-pentanone (Methyl isobutyl ketone) & 4.17 \\
\hline $108-38-3$ & m-Xylene (including 106-42-3 p-Xylene) & 4.42 \\
\hline
\end{tabular}




\begin{tabular}{|c|c|c|}
\hline CAS \# & Name & ppbv to $\mu \mathrm{g} / \mathrm{m}^{3}$ \\
\hline $108-41-8$ & 3-Chlorotoluene (measured as 2- and 3-Chlorotoluene) & 5.26 \\
\hline $108-67-8$ & 1,3,5-Trimethylbenzene & 5 \\
\hline $108-87-2$ & Methylcyclohexane & 4.08 \\
\hline $108-88-3$ & Toluene & 3.83 \\
\hline $108-90-7$ & Chlorobenzene & 4.68 \\
\hline $109-66-0$ & Pentane & 3 \\
\hline $109-67-1$ & 1-Pentene & 2.91 \\
\hline $110-54-3$ & Hexane & 3.58 \\
\hline $110-82-7$ & Cyclohexane & 3.5 \\
\hline $110-83-8$ & Cyclohexene & 3.41 \\
\hline $111-65-9$ & n-Octane & 4.75 \\
\hline $111-66-0$ & 1-Octene & 4.66 \\
\hline $111-71-7$ & Heptanal & 4.75 \\
\hline $111-84-2$ & n-Nonane & 5.33 \\
\hline $1120-21-4$ & n-Undecane & 6.5 \\
\hline $115-07-1$ & Propylene & 1.75 \\
\hline $120-82-1$ & 1,2,4-Trichlorobenzene & 7.54 \\
\hline $123-72-8$ & Butyraldehyde & 3 \\
\hline $123-91-1$ & 1,4-Dioxane (1,4-Diethyloxide) & 3.66 \\
\hline $124-11-8$ & 1-Nonene & 5.25 \\
\hline $124-18-5$ & n-Decane & 5.92 \\
\hline $124-48-1$ & Dibromochloromethane & 8.66 \\
\hline $126-99-8$ & 2-Chloro-1,3-butadiene (Chloroprene) & 3.68 \\
\hline $127-18-4$ & Tetrachloroethene (Perchloroethylene, Tetrachloroethylene) & 6.89 \\
\hline $127-91-3$ & beta-Pinene & 5.66 \\
\hline $1330-20-7$ & mixed Xylenes (see specific m,o, p-xylenes) & 4.42 \\
\hline $138-86-3$ & Limonene & 5.66 \\
\hline $141-32-2$ & Butyl Acrylate & 5.33 \\
\hline $141-93-5$ & 1,3-Diethylbenzene (m-Diethylbenzene) & 5.58 \\
\hline $142-29-0$ & Cyclopentene & 2.83 \\
\hline $142-82-5$ & Heptane & 4.17 \\
\hline $14686-13-6$ & trans-2-Heptene & 4.08 \\
\hline $14686-14-7$ & trans-3-Heptene & 4.08 \\
\hline $156-59-2$ & cis-1,2 Dichloroethene & 4.03 \\
\hline $156-60-5$ & trans-1,2-Dichloroethene & 4.03 \\
\hline $1634-04-4$ & Methyl tert-Butyl Ether & 3.66 \\
\hline $2037-26-5$ & Toluene-d8 (Surrogate) & NA \\
\hline $2198-23-4$ & 4-Nonene & 5.25 \\
\hline $287-92-3$ & Cyclopentane & 2.91 \\
\hline $31394-54-4$ & Isoheptane (2-Methylhexane) & 4.17 \\
\hline $3522-94-9$ & 2,2,5-Trimethylhexane & 5.33 \\
\hline $4050-45-7$ & trans-2-Hexene & 3.5 \\
\hline $463-82-1$ & Neopentane & 3 \\
\hline $496-11-7$ & Indan & 4.91 \\
\hline
\end{tabular}




\begin{tabular}{|c|c|c|}
\hline CAS \# & Name & ppbv to $\mu \mathrm{g} / \mathrm{m}^{3}$ \\
\hline $513-35-9$ & 2-Methyl-2-butene & 2.91 \\
\hline $526-73-8$ & 1,2,3-Trimethylbenzene & 5 \\
\hline $538-93-2$ & Isobutylbenzene & 5.58 \\
\hline $540-84-1$ & 2,2,4-Trimethylpentane (Isooctane) & 4.75 \\
\hline $541-73-1$ & 1,3-Dichlorobenzene & 6.11 \\
\hline $56-23-5$ & Carbon Tetrachloride & 6.39 \\
\hline $563-45-1$ & 3-Methyl-1-butene & 2.91 \\
\hline $564-02-3$ & 2,2,3-Trimethylpentane & 4.75 \\
\hline $565-59-3$ & 2,3-Dimethylpentane & 4.17 \\
\hline $565-75-3$ & 2,3,4-Trimethylpentane & 4.75 \\
\hline $589-34-4$ & 3-Methylhexane & 4.17 \\
\hline 589-81-1 & 3-Methylheptane & 4.75 \\
\hline $590-18-1$ & cis-2-Butene & 2.33 \\
\hline $591-49-1$ & 1-Methylcyclohexene & 4.17 \\
\hline $592-13-2$ & 2,5-Dimethylhexane & 4.75 \\
\hline $592-27-8$ & 2-Methylheptane & 4.75 \\
\hline $592-41-6$ & 1-Hexene & 3.5 \\
\hline $592-76-7$ & 1-Heptene & 4.08 \\
\hline $593-60-2$ & Vinyl bromide & 4.45 \\
\hline $60-29-7$ & Diethyl ether & 3.08 \\
\hline $611-14-3$ & 2-Ethyltoluene (o-Ethyltoluene) & 5 \\
\hline $620-14-4$ & 3-Ethyltoluene (m-Ethyltoluene) & 5 \\
\hline $622-96-8$ & 4-Ethyltoluene (p-Ethyltoluene) & 5 \\
\hline $624-64-6$ & trans-2-Butene & 2.33 \\
\hline $625-27-4$ & 2-Methyl-2-pentene & 3.5 \\
\hline $627-20-3$ & cis-2-Pentene & 2.91 \\
\hline $64-17-5$ & Ethanol (Ethyl alcohol) & 1.92 \\
\hline $646-04-8$ & trans-2-Pentene & 2.91 \\
\hline $66-25-1$ & Hexanal & 4.17 \\
\hline $67-56-1$ & Methanol (Methyl alcohol) & 1.32 \\
\hline $67-63-0$ & 2-Propanol (Isopropyl Alcohol) & 2.5 \\
\hline $67-64-1$ & Acetone (2-Propanone) & 2.42 \\
\hline $67-66-3$ & Chloroform & 4.96 \\
\hline $691-37-2$ & 4-Methyl-1-pentene & 3.5 \\
\hline $691-38-3$ & cis/trans-4-Methyl-2-pentene & 3.5 \\
\hline $693-89-0$ & 1-Methylcyclopentene & 3.41 \\
\hline $71-23-8$ & 1-Propanol & 2.5 \\
\hline $71-36-3$ & 1-Butanol (n-Butyl Alcohol) & 3.08 \\
\hline $71-43-2$ & Benzene & 3.25 \\
\hline $71-55-6$ & 1,1,1-Trichloroethane (Methyl Chloroform) & 5.55 \\
\hline $74-83-9$ & Bromomethane (Methyl Bromide) & 3.95 \\
\hline $74-84-0$ & Ethane & 1.25 \\
\hline $74-85-1$ & Ethylene & 1.16 \\
\hline $74-86-2$ & Acetylene & 1.08 \\
\hline
\end{tabular}




\begin{tabular}{|c|c|c|}
\hline CAS \# & Name & ppbv to $\mu \mathrm{g} / \mathrm{m}^{3}$ \\
\hline $74-87-3$ & Freon 40 Chloromethane (Methyl Chloride) & 2.1 \\
\hline $74-97-5$ & Bromochloromethane & 5.38 \\
\hline $74-98-6$ & Propane & 1.83 \\
\hline $75-00-3$ & Chloroethane (Ethyl Chloride) Freon 160 & 2.68 \\
\hline $75-01-4$ & Vinyl Chloride & 2.6 \\
\hline $75-05-8$ & Acetonitrile & 1.71 \\
\hline $75-07-0$ & Acetaldehyde & 1.83 \\
\hline $75-09-2$ & Methylene Chloride (Dichloromethane) & 3.53 \\
\hline $75-25-2$ & Bromoform & 10.51 \\
\hline $75-27-4$ & Bromodichloromethane & 6.81 \\
\hline $75-28-5$ & Isobutane & 2.42 \\
\hline $75-34-3$ & 1,1-Dichloroethane (Ethylidene Dichloride) & 4.12 \\
\hline $75-35-4$ & 1,1-Dichloroethene (Vinylidene Chloride) & 4.03 \\
\hline $75-43-4$ & Freon 21 (Dichlorofluoromethane) & 4.28 \\
\hline $75-45-6$ & Freon 22 (Chlorodifluoromethane) & 3.6 \\
\hline $75-69-4$ & Freon 11 (Trichlorofluoromethane) & 5.71 \\
\hline $75-71-8$ & Freon 12 (Dichlorodifluoromethane) & 5.03 \\
\hline $75-83-2$ & 2,2-Dimethylbutane (Neohexane) & 3.58 \\
\hline $760-21-4$ & 2-Ethyl-1-butene & 3.5 \\
\hline $76-13-1$ & Freon 113 (1,1,2-Trichloro-1,2,2-trifluoroethane) & 7.79 \\
\hline $76-14-2$ & Freon 114 (1,2-Dichlorotetrafluoroethane) & 7.1 \\
\hline $763-29-1$ & 2-Methyl-1-pentene & 3.5 \\
\hline $7642-04-8$ & cis-2-Octene & 4.66 \\
\hline $7642-09-3$ & cis-3-Hexene & 3.5 \\
\hline $7642-10-6$ & cis-3-Heptene & 4.08 \\
\hline $7688-21-3$ & cis-2-Hexene & 3.5 \\
\hline $78-78-4$ & 2-Methylbutane (Isopentane) & 3 \\
\hline $78-79-5$ & Isoprene & 2.83 \\
\hline $78-87-5$ & 1,2-Dichloropropane (Propylene Dichloride) & 4.7 \\
\hline $78-93-3$ & 2-Butanone (Methyl Ethyl Ketone) & 3 \\
\hline $79-00-5$ & 1,1,2-Trichloroethane & 5.55 \\
\hline $79-01-6$ & Trichloroethene (Trichloroethylene) & 5.46 \\
\hline $79-29-8$ & 2,3-Dimethylbutane & 3.58 \\
\hline $79-34-5$ & 1,1,2,2-Tetrachloroethane & 6.41 \\
\hline $80-56-8$ & alpha-Pinene & 5.66 \\
\hline $811-97-2$ & Halocarbon 134A & 4.24 \\
\hline $821-95-4$ & 1-Undecene & 6.41 \\
\hline $872-05-9$ & 1-Decene & 5.83 \\
\hline $87-68-3$ & Hexachlorobutadiene & 10.84 \\
\hline $91-20-3$ & Naphthalene & 5.33 \\
\hline $922-62-3$ & cis-3-Methyl-2-pentene & 3.5 \\
\hline $95-13-6$ & Indene & 4.83 \\
\hline $95-47-6$ & o-Xylene & 4.42 \\
\hline $95-49-8$ & 2-Chlorotoluene (measured as 2- and 3-Chlorotoluene) & 5.26 \\
\hline
\end{tabular}




\begin{tabular}{|l|l|c|}
\hline \multicolumn{1}{|c|}{ CAS \# } & \multicolumn{1}{|c|}{ Name } & ppbv to $\mathbf{~ g} / \mathbf{m}^{\mathbf{3}}$ \\
\hline $95-50-1$ & 1,2-Dichlorobenzene & 6.11 \\
\hline $95-63-6$ & 1,2,4-Trimethylbenzene & 5 \\
\hline $96-14-0$ & 3-Methylpentane & 3.58 \\
\hline $96-37-7$ & Methylcyclopentane & 3.5 \\
\hline $98-06-6$ & tert-Butylbenzene & 5.58 \\
\hline $98-82-8$ & Isopropylbenzene (Cumene) & 5 \\
\hline $99-87-6$ & 4-Isopropyltoluene (p-Cymeme) & 5.58 \\
\hline
\end{tabular}

\section{Estimate of Particulate Emissions from On-Road Vehicles in the Los Alamos Area}

Section 6.1 of this paper contains a statement that the "particulate matter from commuter traffic in the Los Alamos area is in the range of approximately 21 tons each year." The determination of that number is provided here.

Appendix A of an EPA emissions trends report for 1999 [EPA2001] provides a useful ratio. That EPA report states that 49,989,000 tons of on-road vehicle carbon monoxide (CO) were emitted nationwide in 1999. It also gives a $\mathrm{PM}_{10}$ value of 295,000 tons for those vehicles. Their ratio is almost $170(169.45)$.

In an unpublished report, McBee [McBee2001] estimated that Los Alamos commuter traffic emitted about 4033 tons of $\mathrm{CO}$ each year. That estimate is reasonable. Using 2000 census data [Census2000], the ratio of the Los Alamos County population $(18,343)$ to the US population $(281,421,906)$ is 0.000065 . Assuming Los Alamos vehicle ownership and emissions are similar per capita to the nation, $49,989,000 \times 0.000065=3249$ tons of CO. Plus, a significant number of commuters travel in from Santa Fe and almost none commute out. Thus, 4033 tons of CO is not unrealistic.

Thus, we have $4033 / 170=23.72$ tons as one estimate for Los Alamos vehicle particles. If we work from the nationwide $\mathrm{PM}_{10}$ value and the Los Alamos fractional population, we have $295,000 \times 0.000065=19.2$ tons. The average of the two numbers is 21.5 tons.

Therefore, we estimate that "particulate matter from commuter traffic in the Los Alamos area is in the range of approximately 21 tons each year."

\section{Estimate of Particulate Emissions from Fireplaces in the Los Alamos Area}

Section 6.1 of this paper contains a statement that "Residential fireplaces in the area also contribute substantially to airborne particles, in the rough range of 29 tons/yr." The determination of that number is provided here.

The 2000 Census [Census2000] states that Los Alamos County had 7937 housing units in 2000. The nation had $115,904,641$ housing units. Thus, Los Alamos County has $0.0068 \%$ of the housing units in the country. If we assume that the number of fireplaces per housing unit is the same in Los Alamos as it is nationwide and that their use in Los Alamos is similar to nationwide use, then $0.0068 \%$ of the nationwide fireplace particulate emissions should be a good rough 
estimate of the fireplace emissions in Los Alamos. The EPA ternds report [EPA2001] states that the nationwide fireplace $\mathrm{PM}_{10}$ emissions in 1999 were 431,000 tons.

Thus, we have $431,000 \times 0.000068=29.3$ tons and estimate that "residential fireplaces in the area also contribute substantially to airborne particles, in the rough range of 29 tons/yr."

\section{Estimate of VOC Emissions from On-Road Vehicles in the Los Alamos Area}

Section 6.3 of this paper contains a statement that "... the annual VOC emissions from commuter traffic in Los Alamos are roughly 400 tons per year..." The determination of that number is provided here.

As stated above in the particulate emission estimate for vehicles, the McBee study [Mcbee2001] estimated that non-Laboratory commuter traffic contributes about 4033 tons of CO to the Los Alamos County air each year.

Using the EPA study [EPA2001], the 1999 nationwide CO and VOC on-road vehicle emissions were 49,989,000 and 5,297,000, respectively. Their ratio is 9.44. Thus, we have 4033/9.44= 427 tons as one estimate for Los Alamos vehicle VOCs. If we work from the nationwide VOC value and the Los Alamos fractional population, we have 5,297,000 $\times 0.000065=344$ tons. The average of the two numbers is almost 385.6 tons.

Therefore, we estimate that "the annual VOC emissions from commuter traffic in Los Alamos are roughly 400 tons per year."

\section{Estimate of VOC Emissions from Fireplaces in the Los Alamos Area}

Section 6.3 of this paper contains a statement that "Emissions of VOCs from fireplaces in Los Alamos County are approximately 41 tons per year." The determination of that number is provided here.

Using the fractional housing units $(0.0068 \%)$ determined above and, assuming that the number of fireplaces per housing unit is the same in Los Alamos as it is nationwide and that their use in Los Alamos is similar to nationwide use, then $0.0068 \%$ of the nationwide fireplace VOC emissions should be a good rough estimate of the fireplace emissions in Los Alamos. The EPA trends report [EPA2001] states that the nationwide fireplace VOC emissions in 1999 were 608,000 tons.

Thus, we have $608,000 \times 0.000068=41.3$ tons and estimate that "emissions of VOCs from fireplaces in Los Alamos County are approximately 41 tons per year."

\section{References}

[EPA2001] Environmental Protection Agency, "EPA National Air Quality and Emissions Trends Report, 1999," EPA 454/R-01-004, www.epa.gov/oar/aqtrnd99/ (March 2001). 
[McBee2001] Mitch McBee (Los Alamos National Laboratory), "Estimating Air Emissions from Privately Owned Vehicles Used to Commute to LANL," unpublished Meteorology and Air Quality Group study (2001).

[Census2000] United States Census Bureau (Department of Commerce), "United States Census 2000" [Online], www.census.gov/main/www/cen2000.html. 
This report has been reproduced directly from the best available copy. It is available electronically on the Web (http://www.doe.gov/bridge).

Copies are available for sale to U.S. Department of Energy employees and contractors from: Office of Scientific and Technical Information P.O. Box 62

Oak Ridge, TN 37831

(865) 576-8401

Copies are available for sale to the public from: National Technical Information Service

U.S. Department of Commerce

5285 Port Royal Road

Springfield, VA 22161

(800) 553-6847 
Los Alamos NATIONAL LABORATORY EST.1943 